\title{
LOS DERECHOS DE LOS PUEBLOS INDÍGENAS DE COLOMBIA LUCHAS, CONTENIDO Y RELACIONES
}

Gloria Amparo Rodríguez

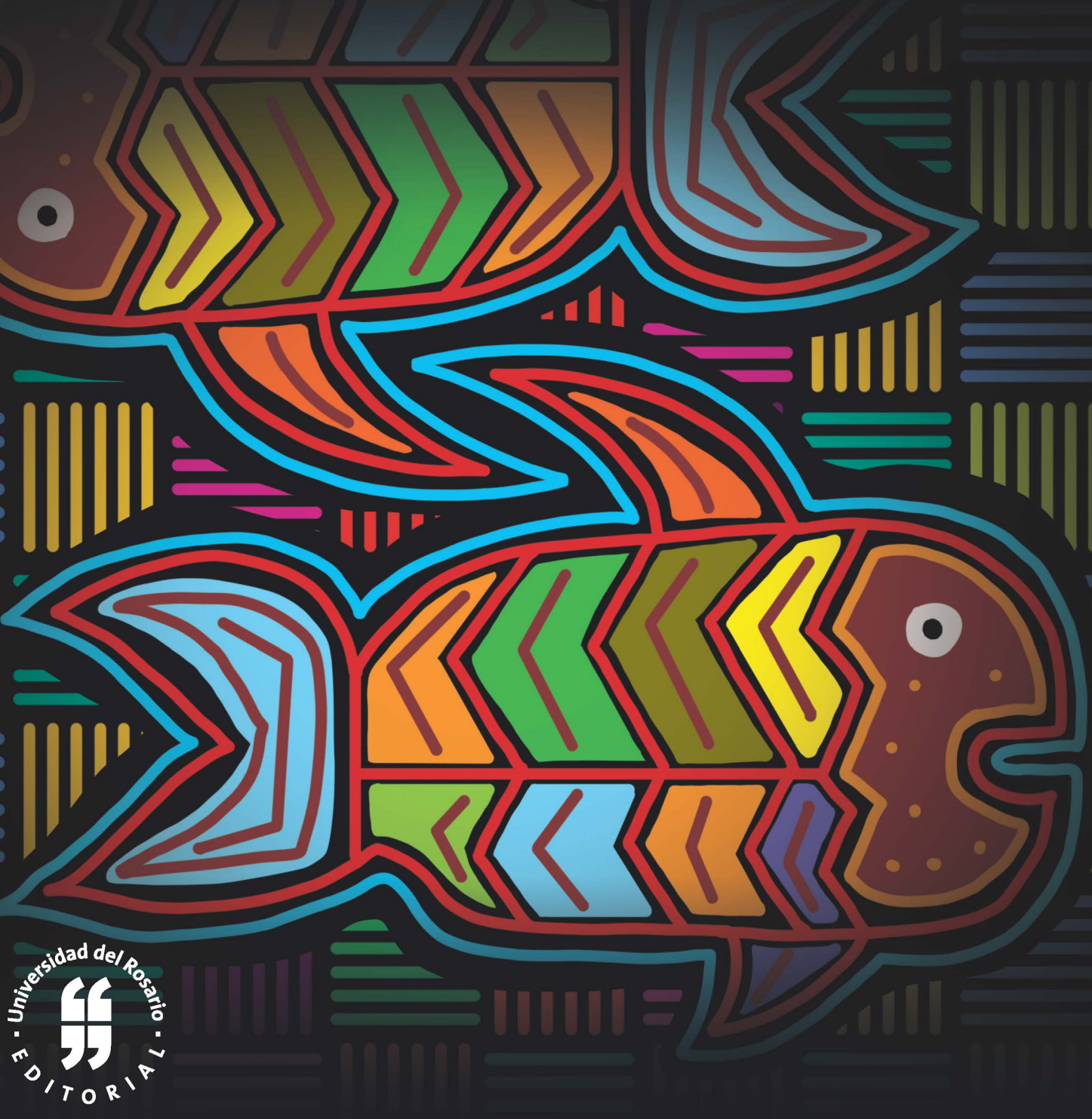




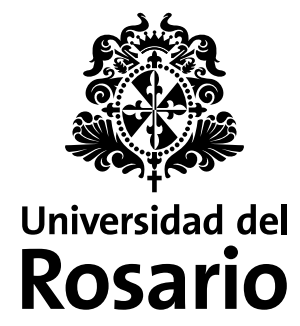



Los derechos de los pueblos indígenas de Colombia

\author{
Luchas, contenido y relaciones
}




\section{Rodríguez, Gloria Amparo}

Los derechos de los pueblos indígenas de Colombia: Luchas, contenido y relaciones / Gloria Amparo Rodríguez. - Bogotá: Editorial Universidad del Rosario, Facultad de Jurisprudencia, 2015.

xiv, 158 páginas. - (Colección Textos de Jurisprudencia)

Incluye referencias bibliográficas.

ISBN: 978-958-738-613-4 (rústica)

ISBN: 978-958-738-614-1 (digital)

Indígenas - Derechos civiles / Indígenas de Colombia / Interculturalidad / Culturas indígenas / Derechos humanos / Indígenas - Participación política / I. Título / II. Serie.

\section{SCDD 20}

Catalogación en la fuente - Universidad del Rosario. Biblioteca

amv

Hecho el depósito legal que marca el Decreto 460 de 1995 


\section{Los derechos de los pueblos indígenas de Colombia Luchas, contenido y relaciones}

Gloria Amparo Rodríguez 
Colección Textos de Jurisprudencia

(C) Editorial Universidad del Rosario

(C) Universidad del Rosario, Facultad de Jurisprudencia

(C) Gloria Amparo Rodríguez

Editorial Universidad del Rosario

Carrera 7 No 12B-41, oficina 501 • Teléfono 2970200

http://editorial.urosario.edu.co
Primera edición: Bogotá D.C., mayo de 2015

ISBN: 978-958-738-613-4 (rústica)

ISBN: 978-958-738-614-1 (digital)

Coordinación editorial: Editorial Universidad del Rosario Corrección de estilo: Manuel Gómez

Diseño de cubierta: Miguel Ramírez, Kilka DG.

Diagramación: Martha Echeverry

Impresión:

Impreso y hecho en Colombia

Printed and made in Colombia

Fecha de evaluación: 28 de enero de 2015

Fecha de aceptación: 17 de marzo de 2015

Todos los derechos reservados. Esta obra no puede ser reproducida sin el permiso previo por escrito de la Editorial Universidad del Rosario. 


\section{Contenido}

Agradecimientos ..................................................................................

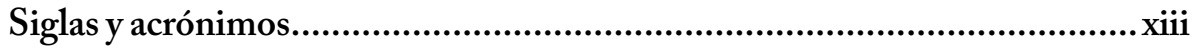

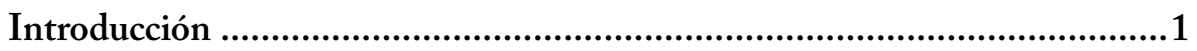

\section{Capítulo 1}

Antecedentes del reconocimiento de los derechos

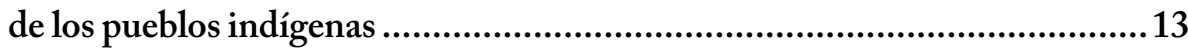

1.1. Concepto pueblos indígenas y tribales ....................................................15

1.1.1. Alcance del concepto pueblos ............................................. 15

1.1.2. Pueblos indígenas y tribales ................................................. 21

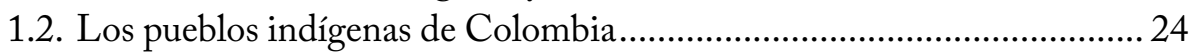

1.3. Fases históricas de las políticas indígenas ............................................. 25

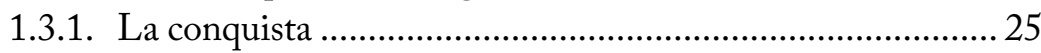

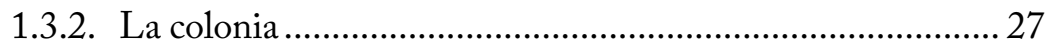

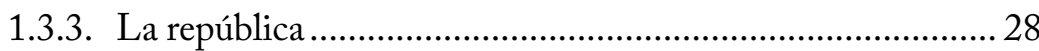

1.3.4. Multiculturalismo y pluralismo jurídico

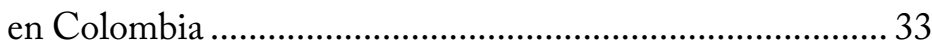

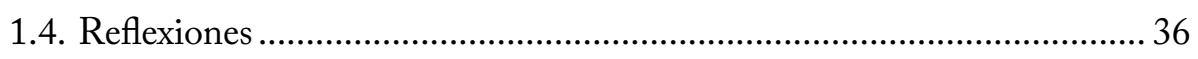

\section{Capítulo 2}

Derechos de los pueblos indígenas consagrados en Colombia......................39

2.1. Alcance y contenido de los derechos ......................................................... 39

2.1.1. Valoración de los instrumentos internacionales ................... 40

2.1.2. Vínculos entre instrumentos internacionales y nacionales....................................................................... 43

2.1.2.1. Derecho a la identidad cultural............................... 46

2.1.2.2. Derecho a la autodeterminación y a la autonomía..................................................5 
2.1.2.3. Derecho al territorio.................................................. 64

2.1.2.4. Derecho a los recursos naturales............................ 71

2.1.2.5. Derecho propio o consuetudinario ....................... 75

2.1.2.6. Derecho a la consulta previa .................................. 84

2.1.2.7. Derecho a la participación .................................... 103

2.2. Incidencia y participación de los pueblos indígenas............................... 108

2.2.1. Sistema de autoridad de los pueblos indígenas ................. 110

2.2.2. Los espacios de participación de los pueblos

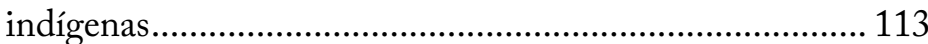

2.2.2.1. Mesa Permanente de Concertación

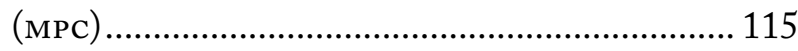

2.2.2.2. Comisión Nacional de Territorios

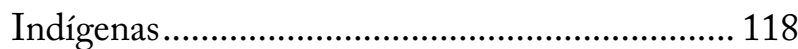

2.2.2.3. Comisión de Derechos Humanos de los Pueblos Indígenas .................................... 119

2.2.3. La participación política de los pueblos indígenas ............. 119

2.3. La consulta y la participación, reiteradas demandas............................... 120

2.4. La función simbólica de los derechos indígenas .................................... 123

2.4.1. Entre la enunciación y el ejercicio

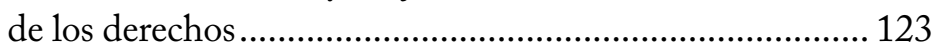

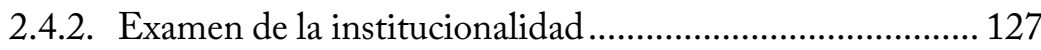

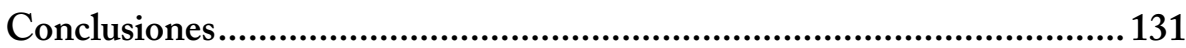

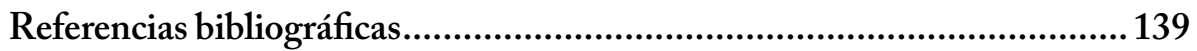




\section{Lista de tablas}

Tabla 1. Países que han ratificado el Convenio 169 de la oit y fecha de ratificación

Tabla 2. Comparación entre los Convenios 107 de 1957 y 169 de 1989 de la oit

Tabla 3. Criterios para la aplicación del Convenio 169 de la OIT

Tabla 4. Comparación entre la propuesta política de Manuel Quintín Lame y la propuesta del cRIC

Tabla 5. Principales instrumentos internacionales de protección de los pueblos indígenas y ley que los ratifica en Colombia

Tabla 6. Población comunidades étnicas en Colombia

Tabla 7. Principales normas sobre consulta previa a pueblos indígenas de Colombia

Tabla 8. Integrantes o actores principales de la Mesa Permanente de Concertación Nacional

\section{Lista de cuadros}

Cuadro 1. Algunos espacios de participación de los pueblos indígenas 2013

\section{Lista de figuras}

Figura 1. Constitución del campo discursivo en la obra de Manuel Quintín Lame

Figura 2. Escenarios de diálogo y concertación con el gobierno nacional, Decretos 1396 y 1397 de 1996

Figura 3. Comisiones temáticas según art. 13 del Decreto 1397 de 1996 



\section{Agradecimientos}

Un agradecimiento especial al profesor Gregorio Mesa Cuadros, quien ha sido mi maestro y amigo. Sin sus aportes y sabiduría no habría podido culminar mi tesis doctoral titulada "Oportunidades y limitaciones de la consulta previa en la prevención y solución de conflictos ambientales en territorios indígenas de Colombia”, que él dirigió. El presente texto corresponde a uno de sus resultados. Espero responder con dignidad a su amistad y a los conocimientos que aporta constantemente a mi vida.

Diversos pueblos indígenas posibilitaron esta investigación. Agradezco a todos ellos el permitirme entrar a sus territorios y compartir largas jornadas de diálogo de saberes, que siempre fluyó y fue transparente, tranquilo y profundo. Deseo, con el resultado de este trabajo, corresponder a la confianza y al afecto manifestado en los encuentros. De manera muy significativa debo hacer un reconocimiento a los pueblos indígenas y sus organizaciones por su apoyo. Los miembros de la onIC, la OPIAC, el cIT, la OIKA y Camawa, entre otros, aportaron elementos y saberes fundamentales para este trabajo. Muchas gracias.

De igual manera, quiero hacer un reconocimiento especial a Lina María Zuluaga, Alejandra Sáenz, Jafeth Paz, Juan Pablo Muñoz, Luz Ángela Patiño, Juan Pablo González y Santiago Martínez, por su incondicional apoyo. Agradezco los aportes y comentarios de los profesores Gloria Patricia Lopera, Érika Castro, Andrés Gómez Rey, Ángela Santamaría, Johanna Cortés, Juan Claudio Arenas y Jimena Sierra. Igualmente, a todas las personas expertas a las que entrevisté y que dieron sus apreciaciones en el curso de la investigación.

Debo agradecer a las directivas de la Universidad del Rosario por permitirme sentir, en mis labores cotidianas y en la misma investigación, que puedo aportar mi granito de arena en la construcción de un mundo mejor, en el que se valore y respete la importancia de nuestro patrimonio natural y cultural.

A mi familia, especialmente a mis tías y hermano, agradezco por apoyarme e impulsarme tanto en los buenos como en los difíciles momentos de mi vida. Por supuesto, agradezco a Misi Rodríguez por acompañarme en silencio 
(desde el escritorio de al lado) mientras trabajaba. En especial, por entender la falta de caricias y juegos en el tiempo que duró este proceso.

Aprecio y agradezco inmensamente el apoyo que quienes me rodean brindaron a esta investigación. Espero contribuir con ella a la reflexión acerca de un nuevo modo de ver el mundo y descubrir que entre todos podemos lograr una sociedad justa y equitativa, donde además se proteja el entorno y se respeten y valoren otras culturas. A todos, muchas gracias. 


\section{Siglas y acrónimos}

ANUC: Asociación Nacional de Usuarios Campesinos

Art.: Artículo

c: Sentencia de Constitucionalidad

Camawa: Asociación de Autoridades Wounaan del Pacífico

ccc: Corte Constitucional Colombiana

CERD: Comité para la Eliminación de la Discriminación Racial (CERD, por sus siglas en inglés)

Cerrem: Comité de Evaluación de Riesgo y Recomendación de Medidas

сіт: Confederación Indígena Tayrona

CLPI: Consentimiento Libre, Previo e Informado

Com. DH: Comité de Derechos Humanos

Contcepi: Comisión Nacional de Trabajo y Concertación para la Educación de los Pueblos Indígenas

Corte IDH: Corte Interamericana de Derechos Humanos

CP: Constitución Política de Colombia

CRIC: Consejo Regional Indígena del Cauca

csJ: Consejo Superior de la Judicatura

DANE: Departamento Administrativo Nacional de Estadística

DGAI: Dirección General de Asuntos Indígenas

DGN: Dirección General de Negritudes

DNP: Departamento Nacional de Planeación

DNUDPI: Declaración de Naciones Unidas sobre los Derechos de los Pueblos Indígenas

Ecopetrol: Empresa Colombiana de Petróleos

IAP: Investigación Acción Participativa

Ideam: Instituto de Hidrología, Meteorología y Estudios Ambientales de Colombia

III: Instituto Indigenista Interamericano

Incoder: Instituto Colombiano de Desarrollo Rural 
Jude: Junta Departamental de Educación

Jume: Junta Municipal de Educación

MADs: Ministerio de Ambiente y Desarrollo Sostenible

MIJ: Ministerio del Interior y de Justicia

mMA: Ministerio de Medio Ambiente

MP: Magistrado Ponente

MPC: Mesa Permanente de Concertación de Pueblos Indígenas

OEA: Organización de los Estados Americanos

Oika: Organización Indígena Kankuama

оIт: Organización Internacional del Trabajo

ONG: Organización No Gubernamental

ONIC: Organización Nacional Indígena de Colombia

ONU: Organización de las Naciones Unidas

OPIAC: Organización de los Pueblos Indígenas de la Amazonía Colombiana

отса: Organización del Tratado de Cooperación Amazónica

PGN: Procuraduría General de la Nación

PND: Plan Nacional de Desarrollo

su: Sentencia de Unificación

$\mathrm{T}$ : Sentencia de Tutela

Unesco: United Nations Educational, Scientific and Cultural Organization

(Organización de las Naciones Unidas para la Educación, la Ciencia y la Cultura)

UPME: Unidad de Planeación Minero-Energética 


\section{Introducción}

Actualmente en Colombia existen 102 pueblos indígenas ${ }^{1}$ que se constituyen en símbolo de la diversidad de lenguas maternas, usos, costumbres y de una cosmovisión especial. ${ }^{2}$ Ellos representan el 3,3 \% de la población nacional y se encuentran distribuidos en casi la totalidad de los departamentos del país.

Según la Presidencia de la República $(2013,11)$, los departamentos con mayor población indígena con respecto al total indígena nacional son $\mathrm{La}$ Guajira, con el 20,18 \%; Cauca, con el 17,98 \%; Nariño, con el 11,22 \%, y Córdoba, con el 10,96\%.

Sobre este particular, la Organización Nacional Indígena de Colombia —en adelante ONIC - plantea que, aunque se pueden encontrar indígenas a lo largo y ancho del territorio nacional, existen zonas en las que hay una mayor densidad demográfica; dichos pueblos constituyen alrededor de la mitad de la población. Específicamente, en algunos departamentos como Guainía, Vaupés, La Guajira, Amazonas y Vichada. Así mismo, señala que el 78 \% de los indígenas habita en zonas rurales o en territorios que se encuentran organizados como resguardos, ${ }^{3}$ parcialidades indígenas o territorios no delimitados legalmente, mientras que el $22 \%$ habita en zonas urbanas. Sin embargo, según la ONIC $(2010,7)$, en los últimos años ha sido progresiva la migración de los pueblos indígenas colombianos hacia las ciudades, como consecuencia

\footnotetext{
${ }^{1}$ En este texto se hará mención al término pueblos indígenas como lo hace el Convenio 169 de la oIT, ya que este reconoce la existencia de sociedades organizadas con identidad propia, en lugar de simples agrupaciones de individuos que comparten algunas características raciales o culturales. Profundizaremos más adelante sobre las discusiones que se han dado con relación a este término. Cuando en el texto se hace referencia a grupos étnicos o pueblos étnicos debe entenderse que nos estamos refiriendo a los pueblos indígenas, afrocolombianos, negros, raizales, palenqueros y rom o gitanos.

2 Ver estadística del Censo 2005 en www.dane.gov.co.

${ }^{3} \mathrm{El}$ resguardo es la forma jurídica que representa la propiedad colectiva reconocida por el Estado a los pueblos indígenas, que se caracterizan por ser inalienables, imprescriptibles e inembargables (artículo 63 de la Constitución Política de Colombia, Ley 160 de 1994 y Decreto 2164 de 1995).
} 
de factores relacionados con el agotamiento de las tierras disponibles en los resguardos y el desplazamiento forzado.

En este mismo sentido, el Programa Presidencial Indígena menciona que a pesar de la existencia de un marco normativo de protección, no hay duda que a las regiones donde habitan en su mayoría los pueblos indígenas se encuentran asociados indicadores que presentan menor acceso a la educación, la salud, la alimentación, el saneamiento básico, entre otros, los cuales son abordados como elementos constitutivos del empobrecimiento de dichas comunidades (Colombia, Presidencia de la República 2013, 20). Por esta razón, se hace necesario profundizar en el análisis de los principales derechos de estas colectividades y de las actuaciones de las instituciones del Estado, con el fin de protegerlos.

Debemos mencionar que los pueblos indígenas gozan de los derechos humanos y libertades fundamentales consagrados en la Constitución Política del país, en el Convenio 169 de 1989 de la Organización Internacional del Trabajo (en adelante, oit) (ratificado en el año 19914) y en otras normas reglamentarias. Sin embargo, como lo dice Botero Marino (2003, 54), la Constitución, de carácter multicultural, no se agota en las disposiciones constitucionales: en la gran mayoría de las decisiones relativas a conflictos entre unidad y diversidad cultural, la Corte Constitucional ha entendido que los tratados internacionales ratificados por Colombia, que promueven el reconocimiento y la defensa de la diversidad cultural ${ }^{5}$ son normas directamente aplicables en el ordenamiento jurídico interno. En suma, el marco jurídico de las decisiones del tribunal constitucional en estas materias está integrado, fundamentalmente, por normas de derecho interno y de derecho internacional que establecen reglas, principios y valores dirigidos a regular los conflictos.

\footnotetext{
${ }^{4}$ Resaltamos que el Convenio 169 de la ort, sobre pueblos indígenas y tribales, fue adoptado en Ginebra durante la 76a Reunión de la Conferencia General (1989). En esta ocasión se consideró que la evaluación del derecho internacional desde 1957 (cuando se había suscrito el Convenio 107) y los cambios sobrevinientes en la situación de los pueblos en todas las regiones del mundo hacían aconsejable adoptar nuevas normas internacionales a fin de eliminar la orientación hacia la asimilación.

${ }^{5}$ La Unesco promulgó la Convención sobre la Protección y Promoción de la Diversidad de las Expresiones Culturales, en la cual confirma que la diversidad cultural es una característica esencial de la humanidad que constituye un patrimonio común que debe valorarse y preservarse en provecho o en pro de la pervivencia física y cultural de todos.
} 
En ese sentido, el Estado colombiano tiene varias obligaciones orientadas a proteger los derechos de estos pueblos y a garantizar el respeto de su integridad. Así las cosas, es indispensable adelantar una acción coordinada y sistemática, con medidas que aseguren que dichos pueblos gocen de los derechos y oportunidades otorgadas al resto de la población; también, debe promover la efectividad de los derechos sociales, económicos y culturales de los que ellos son titulares y, además, eliminar las diferencias socioeconómicas de una manera compatible con sus aspiraciones y formas de vida, como lo consagra la Ley 21 de 1991, que ratifica el mencionado convenio.

Los derechos de los pueblos indígenas se constituyen actualmente en un reto para la gobernabilidad, la democracia y la ciudadanía. No obstante, el Estado, los gobiernos nacionales, las políticas públicas y la institucionalidad en general no han podido asimilar la diversidad cultural existente en nuestro país, como lo estableceremos a continuación en esta investigación. El serio proceso de mestizaje cultural ha conducido a la exclusión e invisibilidad histórica de los pueblos y las comunidades indígenas (Regalado Gutiérrez 2010, 50).

Particularmente, para superar esta situación, está prohibido en cumplimiento del Convenio 169 adoptar normas que impidan la garantía de los derechos que protegen a los pueblos indígenas, lo cual significa que cualquier disposición legal expedida en el país debe estar acorde con lo consagrado en este instrumento internacional.

En atención a dicha problemática, venimos adelantando un proyecto de investigación y el análisis que se presenta a continuación parte de la siguiente pregunta: ¿cuáles son los principales derechos que tutela el Estado colombiano a favor de los pueblos indígenas y qué balance puede hacerse de esa aplicación?

Sobre este marco investigativo, es importante aclarar que este documento corresponde a uno de los capítulos de la tesis doctoral titulada "Oportunidades y limitaciones de la consulta previa en la prevención y solución de conflictos ambientales en territorios indígenas de Colombia”, cuyo objetivo es analizar, desde la base del estudio de casos de consulta previa integral, las problemáticas de este derecho fundamental y establecer la manera como este derecho contribuye a las garantías de los derechos a la autonomía, el territorio, los recursos naturales y la participación de estas colectividades, constituyéndose en un instrumento para la prevención y solución de los conflictos ambientales en sus territorios. 
Para el desarrollo de la investigación en mención, se analizan los derechos más relevantes de los pueblos indígenas en el orden jurídico nacional e internacional, los cuales pueden ser vulnerados de una u otra forma en los casos generadores de conflictos ambientales. El presente documento presenta los resultados de esta parte de la investigación final.

En este proyecto investigativo se utilizan varios recursos metodológicos inspirados en la Investigación Acción Participativa (IAP), partiendo de la premisa de que los pueblos indígenas, debido a sus conocimientos y prácticas tradicionales, desempeñan un papel fundamental en la ordenación del ambiente y en el desarrollo. Por esta razón, el Estado debe reconocer y apoyar su identidad, cultura e intereses. De igual forma, debe hacer efectiva su participación en el desarrollo del país al igual que garantizar sus derechos.

Ese enfoque lo hemos denominado en esta investigación como un "enfoque integral” que implica, sobre todo, establecer mediante el diálogo el respeto a las formas de ver el mundo y el desarrollo propias de los pueblos indígenas; la garantía de sus derechos al territorio, a la autonomía, a los recursos naturales y a la participación. Dicho tratamiento contempla aspectos económicos y destaca otros de igual o mayor importancia, como las formas de vida y de gobierno de los pueblos indígenas, al igual que su concepción de los territorios, donde reproducen la cultura, solucionan sus conflictos y, además, encuentran sus sitios sagrados.

En esa ruta, nuestra investigación estudia las principales garantías a favor de los pueblos indígenas y la forma como estas se ven comprometidas. En este proceso, se puede evidenciar la brecha entre su consagración y el efectivo ejercicio de los derechos. El estudio parte de una revisión de las normas y para ello se utiliza un método exploratorio-descriptivo, consistente en identificar los tratados internacionales y las normas nacionales en favor de los pueblos indígenas. De igual forma, analiza la doctrina existente sobre el particular y la principal jurisprudencia emanada de la Corte Constitucional. Los recursos metodológicos también se relacionan con los requerimientos de información y el análisis específico del tema jurídico.

Como se mencionó anteriormente, con base en la metodología de la Investigación-Acción Participativa, IAP, impulsada en nuestro país por el profesor Orlando Fals Borda, el proyecto se adelanta en un marco que posibilita como estrategia la participación de todos los actores involucrados, con el fin de afianzar el diálogo y la concertación entre las partes y permitir 
el empoderamiento de las comunidades, en nuestro caso específico, de los pueblos indígenas.

Dicha acción se orienta no sólo a la investigación y no es únicamente, como lo plantea el profesor Fals Borda (1991, 9), educación de adultos o acción socio-política, sino que abarca todos estos aspectos desarrollados en forma de etapas o fases, que pueden estar combinadas en una metodología experimental, es decir, inmersa en un proceso de comportamiento personal y colectivo que ocurre en un ciclo de vida y trabajo productivo y satisfactorio. Esta metodología implicó la adquisición de un conocimiento serio y confiable sobre el cual construir 'poder' para los grupos y clases sociales y para sus organizaciones y movimientos auténticos, en este caso, para los pueblos indígenas afectados por los conflictos analizados. Las metas de esta combinación de conocimiento de trabajo, respondiendo a la IAP, fueron: 1) capacitar a los grupos y 2) producir y desarrollar un proceso de pensamiento sociopolítico con el que las bases se puedan identificar. Por ello se efectuaron talleres con estas comunidades.

La investigación sobre los aspectos jurídicos parte de la nueva concepción multicultural del Estado colombiano, adoptada en la Constitución Política de 1991. Al respecto, este estudio muestra que los programas y políticas generados a la luz de esa concepción, cuya formulación señala el propósito de garantizar los derechos de los pueblos indígenas y aparece en los documentos de política pública, no obstante, terminan por presentar falencias en su aplicación.

En este documento, el análisis de los derechos a la cultura, al territorio, a la autonomía, a la participación y a los recursos naturales se basa en el enfoque de los derechos humanos, aunque se reconoce la visión de los pueblos indígenas y de algunos doctrinantes sobre la necesidad de asignar derechos a otros seres de la naturaleza. En el análisis jurídico también se tuvo en cuenta que existen factores que imposibilitan hacer efectivos dichos derechos, entre los cuales se encuentra el conflicto armado que vive nuestro país y que se refleja en los casos de conflictos que actualmente se presentan.

Bajo este panorama, nuestra investigación considera los procesos de definición de las políticas públicas y del desarrollo del país que involucran a los pueblos indígenas, teniendo en cuenta la ponderación y la armonización de los derechos. Coincidimos con Hernández Meza $(2003,198)$ en la perspectiva de entender que la coalición entre derechos fundamentales y principios constitucionales demanda una interpretación por parte del juez constitucional que 
observe que la aplicación de un bien constitucionalmente protegido debe no implicar la paralela eliminación de otro. Para ello, consideramos que además se debe aplicar el "principio de la armonización" concreta, que pondera los bienes constitucionales enfrentados en cada caso concreto. ${ }^{6}$

Para su análisis es necesario estudiar de manera profunda y crítica la más relevante jurisprudencia emanada de la Corte Constitucional, que mediante sus providencias se ha constituido en el principal estamento de protección de los derechos. Como lo ha planteado el profesor Bonilla Maldonado (2006: 25), el caso de Colombia es paradigmático, ya que si bien en este país es significativa la presencia histórica y cultural de grupos indígenas y de afrocolombianos, casi nunca se han considerado sus exigencias y necesidades. Además, en los pocos casos en que han sido tenidas en cuenta, tampoco se ha evaluado su plausibilidad a través de la perspectiva del liberalismo, paradójicamente, desarrollando uno de los marcos constitucionales y jurídicos más progresistas en América Latina en lo que concierne a asuntos multiculturales. Los desarrollos jurídicos colombianos han sido considerados por activistas y por personas encargadas del diseño de políticas públicas como un ejemplo del tipo de legislación que otros países de la región debieran adoptar. Para esta labor de estudio jurisprudencial, se establece y utiliza una metodología de análisis sobre la cual se trabajan los respectivos derechos que consideramos más relevantes.

Se resalta además que esta investigación se sustenta en diversas discusiones sobre los derechos de los pueblos indígenas, que parten de los aportes o las herramientas teóricas que en esta materia representan autores o doctrinantes como James Anaya, Raquel Z. Yrigoyen, Esther Sánchez Botero, Daniel Bonilla Maldonado, Marco Aparicio, Catalina Botero Marino, Boaventura de Sousa Santos, Mikel Berraondo, Gregorio Mesa Cuadros, Rosembert Ariza Santamaría, Gloria Lopera y Libardo José Ariza, entre otros. ${ }^{7}$

De igual forma, el marco jurídico actual se compone de una serie de normas que en Colombia se constituyen en elemento fundamental para la garantía de los derechos y la pervivencia de los pueblos indígenas. A través

\footnotetext{
${ }^{6}$ Para profundizar en la aplicación del principio de la armonización se sugiere ver Pagliari (2009) y Hernández Meza (2003).

${ }^{7}$ Es necesario aclarar que en esta investigación no consideramos pertinente efectuar un análisis de derecho comparado dado el escaso avance jurisprudencial en otros países. Dicho estudio puede constituirse en una investigación a efectuar en próximos trabajos.
} 
de este trabajo, se pretende presentar no solamente el desarrollo sino las limitaciones, que se han constituido en fuente para la judicialización en busca de su reivindicación y lucha.

Afirma López Medina (2007,xx) que las transformaciones del derecho constitucional en Colombia pueden ser analizadas desde varios puntos de vista. El cambio ha sido aparentemente conducido por medio de los instrumentos tradicionales del derecho positivo, es decir, de normas jurídicas de varias clases, tenidas como obligatorias por sus destinatarios. Estas normas brindan el marco jurídico positivo en el que se desenvuelve el debate sobre el contenido, la forma y los fines del derecho constitucional.

Como se ha mencionado, Colombia ha desarrollado uno de los marcos constitucionales y jurídicos más avanzados en lo que concierne a asuntos multiculturales (Bonilla Maldonado 2006, 25). Sobre esta base, el presente documento investigativo busca analizar los principales pronunciamientos constitucionales, legales y jurisprudenciales de los derechos que se encuentran comprometidos. El resultado muestra cómo este mapa de reglas constitucionales, legales y pronunciamientos judiciales no pueden limitarse a la paráfrasis o exposición lineal del derecho positivo vigente en la materia, porque, de hecho, como lo plantea el profesor López Medina (2007, xx), no existe tal derecho linealmente ordenado en espera de simple descripción.

Así las cosas, este estudio sobre derechos fundamentales cuenta con una metodología para el análisis que incluye la identificación preliminar, desde una visión integral de los derechos, de las principales sentencias relacionadas con los derechos de los pueblos indígenas vulnerados con ocasión de los conflictos que acontecen en nuestro país. Esa visión de los derechos humanos se sustenta en su interdependencia, interrelación, universalidad, globalidad y tratamiento igual y se basa en una perspectiva crítica, como lo asegura el profesor Mesa Cuadros $(2007,17)$.

Vale la pena reiterar que Colombia es el país con más desarrollos legales y jurisprudenciales sobre el tema del sujeto colectivo (pueblos indígenas). Esto genera numerosos conflictos jurídicos y políticos. Sin embargo, aunque el reconocimiento jurisprudencial termina siendo un motivo de lucha social por la defensa de los derechos colectivos, deja sin resolver la dramática situación de los pueblos (Ariza Santamaría 2012: 284). Por eso, consideramos necesario y pertinente analizar las providencias que han emanado de la Corte Constitucional sobre los derechos de los pueblos indígenas. 
El estudio de las normas y las decisiones más relevantes de los derechos de los pueblos indígenas pretende establecer los criterios que ofrece la jurisprudencia para resolver los conflictos propios de un Estado multicultural, sin que esto suponga que ella es completamente coherente y que responda plenamente a los imperativos de un modelo constitucional multicultural. Como lo ha asegurado Botero Marino $(2003,45)$, y como se establece en el desarrollo de esta investigación, en esta materia es, en algunos casos, equívoca y contradictoria.

Es necesario resaltar que el comienzo de lo que podríamos llamar la era del multiculturalismo en Colombia delimita la presente investigación; es decir, a partir del año 1991. El multiculturalismo como teoría y filosofía es una respuesta y una reacción a la manera de aproximarse al mundo desde una perspectiva exclusivista y monista, en la que se ignoran cosmovisiones de la sociedad y de los seres humanos diferentes a la visión occidental. Su efecto en el plano jurídico es el reconocimiento ${ }^{8}$ de la diversidad étnica y cultural, que implica una ruptura con el monismo jurídico tradicional que caracterizó al derecho hasta comienzos de la década de los ochenta.

El surgimiento del multiculturalismo como un nuevo paradigma y su influencia en la construcción de las normas en la perspectiva constitucional han tenido dos ciclos de evolución: el primero ocurrió en la década de los ochenta en Canadá (1982), Guatemala (1985), Nicaragua (1987) y Brasil (1988), y el segundo, propio de los años noventa, tras la incorporación de los contenidos del Convenio 169 de la oIT, cuando se incluyó el paradigma en las constituciones de Colombia (1991), México (1992), Paraguay (1992), Perú (1993) Bolivia (1994), Argentina (1994), Ecuador (1996) y (1998) y Venezuela (1999) (Santos 2010,13).

La teoría contemporánea del multiculturalismo se ha centrado en diversos problemas: uno descriptivo y otro normativo. Con respecto al problema descriptivo, trata de precisar y comprender los retos que tienen las democracias liberales, dado su carácter multicultural. En relación con el normativo, intenta articular modelos prescriptivos que permitan acomodar y reconocer

\footnotetext{
${ }^{8}$ Las exigencias de reconocimiento de la diferencia alimentan las luchas de grupos que se movilizan bajo las banderas de la nacionalidad, la étnia, la raza, el género y la sexualidad. Según Fraser (1997, 17), la identidad de grupo sustituye a los intereses de clase como mecanismo principal de movilización política. A la vez, el reconocimiento cultural desplaza a la distribución socioeconómica como remedio a la injusticia y objetivo de la lucha política.
} 
justamente a las minorías culturales en las democracias liberales. En particular, los teóricos del multiculturalismo luchan por encontrar soluciones plausibles a las tensiones que existen entre los derechos individuales y la diferencia cultural. Sin embargo, esos marcos descriptivo y normativo generales no son usualmente suficientes para solucionar los problemas relacionados con cuestiones multiculturales (Bonilla Maldonado 2006, 107). ${ }^{9}$

A pesar de ello, bajo este principio del multiculturalismo, varios países de la región han modificado sus textos constitucionales, adoptando además normas legislativas y administrativas relativas al estatuto de los derechos de las colectividades indígenas, afectando a las instituciones que les atañen y a los recursos que les son esenciales para su vida (Fondo Indígena 2012,17).

Adicionalmente, se registra otro ciclo de los efectos constitucionales del multiculturalismo con la adopción de la Declaración de las Naciones Unidas sobre los Derechos de los Pueblos Indígenas (2006-2007) —en adelante, DNUDPI ${ }^{10}$ - y con los procesos constituyentes de Bolivia (2006-2009) y Ecuador (2008), mediante la adopción del “Estado Plurinacional” (Santos 2010,13).

Desde ese enfoque, a partir de la Constitución Política colombiana, se habla de un Estado social de derecho, democrático, participativo y pluralista, donde se reconoce y protege la diversidad étnica y cultural de la nación colombiana:

A partir de que Colombia se estructura como Estado Social de De-
recho y asume para sí una postura multicultural, la diversidad hace su
aparición como un actor constructor de sociedad [...] Encontramos
entonces que el multiculturalismo se desarrolla a partir del recono-
cimiento y la pluralidad cultural que tienen como fin la convivencia,

\footnotetext{
${ }^{9}$ Según Bonilla Maldonado $(2006,107)$, asuntos como los poderes legales y políticos concretos que deben tener las minorías culturales, las formas en que deben resolverse los conflictos de jurisdicción entre las minorías y las mayorías, y las reglas e instituciones que deben guiar la relación entre las autoridades nacionales y las minorías culturales no son discutidas por los filósofos políticos en el multiculturalismo. Mientras la teoría multicultural busca solucionar problemas abstractos de manera abstracta, la práctica constitucional intenta solucionar problemas concretos de manera concreta.

${ }^{10}$ Declaración aprobada el 13 de septiembre de 2007 por la Asamblea General de la Organización de Naciones Unidas (ONU), después de más de veinte años de trabajo. Es importante aclarar que mientras un convenio es un instrumento jurídico internacional que vincula legalmente a los países que los ratifican, una declaración adoptada en los escenarios internacionales, que se encarga de definir los principios y lineamientos de política deseable, no tiene carácter vinculante.
} 
el respeto y la aceptación dentro de la diferencia cultural. (Cortés Gómez 2009,173-175)

Sobre este particular el profesor Borrero García $(2009,68)$ plantea que los estudiosos colombianos tienen una especie de acuerdo teórico sobre el sentido de los términos 'multiculturalismo'e 'interculturalismo'. ${ }^{11}$ Resalta que el primero alude a una integración de culturas subordinadas a una cultura hegemónica o mayoritaria, y el segundo representa los esfuerzos por lograr la integración horizontal o mutuamente respetuosa entre culturas diversas, sin atender asuntos como mayorías o minorías. La interculturalidad tendría que ver con el respeto de la autonomía de las formas de derecho propio de cada cultura.

Bajo este enfoque, existen razones que fundamentan la delimitación del período de investigación de 1991-2012: la primera tiene que ver con la ratificación del Convenio 169 de la oIT, que se produce en 1991 mediante la Ley 21. Este instrumento internacional hace parte del bloque de constitucionalidad ${ }^{12}$ y se orienta a garantizar este derecho fundamental de los pueblos indígenas y, de esta manera, proteger su integridad cultural, social y económica. Ese paso respondió al hecho de que "la estructura de las sociedades modernas se está viendo crecientemente afectada por el fenómeno de la multiculturalidad, algo que plantea nuevos conflictos y cuestiones en la medida en que las minorías étnicas y nacionales piden que se reconozca y se apoye su identidad cultural" (Kymlicka 1996, contraportada).

La segunda razón de la delimitación temporal de la investigación tiene que ver con el hecho de que desde 1991 el país cuenta con una nueva Constitución Política que, como se mencionó, define a Colombia como un Estado social de derecho, lo que significa que su principal objetivo es resguardar una

${ }^{11}$ La declaración del país como multiétnico y pluricultural supone una lectura en positivo de los derechos derivados de dichas condiciones, para lo cual es importante dar un debate más profundo sobre el tema de estos derechos dirigidos a la protección y fortalecimiento de cuatro grupos étnicos diferenciados, como lo ha planteado recientemente el profesor Borrero García (2014).

${ }^{12}$ La teoría del bloque de constitucionalidad, tal y como ha sido recibida en Colombia, propone, en pocas palabras, que el derecho constitucional no se agota en la literalidad del texto constitucional. Según esta doctrina, el derecho constitucional incluye, entre otras cosas, las disposiciones - y reglas adscritasdel derecho internacional de los derechos humanos cuando quiera que estas se encuentren contenidas en tratados internacionales ratificados por Colombia (Botero Marino 2003, 55). Se sugiere ver sobre el particular Quinche Ramírez (2014). 
existencia digna para todos. Este precepto, en últimas, implica que el Estado debe garantizar el bienestar social de los ciudadanos, mediante el aseguramiento de una situación social, cultural, ambiental y económica adecuada, tema que retomaremos más adelante. La Carta Política también establece unos derechos y unos deberes tanto para el Estado como para los particulares, mediante los cuales pretende, además de proteger la diversidad étnica y cultural, conservar el ambiente y garantizar una calidad de vida adecuada para los ciudadanos (artículos 7, 8, 63, 79, 80 y 95.8).

No obstante lo anterior, el multiculturalismo como principio constitucional fue concomitante con profundas reformas del Estado en materia de globalización, que condujeron a la flexibilización de los mercados, mayor apertura económica, ingreso de trasnacionales y acomodamiento de los ordenamientos jurídicos a los presupuestos del neoliberalismo. Lo anterior implica contrastes e inconsistencias, porque al tiempo que se adoptaron y ofrecieron garantías para los derechos indígenas, se impulsaron "políticas que [permitieron] nuevas formas de despojo territorial como no se había dado desde el siglo xix" (Santos 2010,13). Esta tensión subyacente en la Constitución Política de Colombia es uno de los factores generadores de los conflictos en su versión contemporánea.

El documento final de esta parte de la investigación alude en la primera parte a los antecedentes de la lucha de los pueblos indígenas por el territorio y la defensa de sus derechos. Presenta las fases históricas de las políticas indígenas en Colombia y los componentes jurídicos internacionales más relevantes para el debate y se aproxima a la realidad jurídica de estos pueblos en el orden internacional, dando una mirada a los sucesos que dieron lugar a la expedición de normas de protección, ya fuese por medio de la asimilación (como ocurrió en los primeros tiempos) o ante el reconocimiento de la diversidad cultural y sus formas de manifestarse (como ocurrió en tiempos más recientes).

La segunda parte del trabajo de investigación se centra en los pueblos indígenas de Colombia, sus derechos y la lucha por el territorio. Por esta razón, ahonda en los escenarios de participación y sistemas de autoridad, elementos fundamentales a tener en cuenta en el marco de los problemas y la judicialización que actualmente se presenta. Estos sujetos de derechos especiales tienen reconocimientos que son el resultado de sus demandas y luchas, invisibilizadas hasta ahora en los registros históricos. Son esas mismas demandas las que hoy los enfrenta con actores interesados en utilizar sus recursos naturales y 
controlar sus territorios. En este sentido, se abordan aspectos políticos y jurídicos, que nos permiten efectuar el análisis de la realidad actual de estos pueblos.

Para finalizar debemos señalar que el presente documento de investigación es resultado de una labor de larga data que ha venido rondando la mente de la autora desde el momento en el que adelantó sus estudios de Especialización en Derecho Ambiental en la Universidad del Rosario, pues en desarrollo de uno de los trabajos debió analizar lo que en ese momento (1996) estaba aconteciendo con la exploración petrolera en territorio de los U'was (uno de los casos que se analizan). Este fue el primer acercamiento hacia estas temáticas desde un enfoque integral de derechos, desde el cual es posible establecer cómo diversos pueblos indígenas se enfrentan a los gobiernos y los dueños de los proyectos en defensa sus derechos, de su identidad cultural y de sus territorios. 


\section{Capítulo 1 \\ Antecedentes del reconocimiento de los derechos de los pueblos indígenas}

Con el fin de ofrecer un contexto más amplio de los derechos de los pueblos indígenas, a continuación se efectúa un breve análisis de los antecedentes nacionales e internacionales que han dado lugar a su consagración, el cual corresponde, en especial, a sus luchas en defensa del territorio y la autonomía.

En el mundo de hoy, las reivindicaciones de justicia social parten de las 'reivindicaciones redistributivas' que pretenden una distribución más justa y equitativa de los recursos y de la riqueza, pero se desplazan hacia la justicia social en la 'política del reconocimiento', que, como lo plantea Fraser (2008, 83), tiene como objetivo un mundo que acepte la diferencia, en el que el precio por el respeto no sea la integración a la mayoría o la asimilación de las normas culturales dominantes por parte de estos pueblos.

Así, florecen con mayor vigor los derechos de los pueblos indígenas que son estudiados en este trabajo, puesto que se ha vuelto familiar ese discurso para nosotros. Y lo es en dos esferas: en la esfera íntima, en la que comprendemos que la formación de la identidad y del yo tiene lugar en un diálogo sostenido y en pugna con los otros significantes. Y en la esfera pública, donde la política del reconocimiento igualitario desempeña un papel cada vez mayor (Taylor 2003, 59). ${ }^{13}$

Yrigoyen Fajardo $(2010,16)$ denomina este proceso acaecido en las últimas décadas como "Horizonte del constitucionalismo pluralista", y señala también tres ciclos diferenciados: la emergencia del multiculturalismo en los años ochenta del siglo xx, el reconocimiento del Estado pluricultural y el

\footnotetext{
${ }^{13}$ La idea de política de reconocimiento se puede encontrar en la obras de Charles Taylor. No obstante, el filósofo canadiense impulsa la tesis de una política de reconocimiento desde el marco de una visión comunitarista, lo que no resultaría del todo coherente con un modelo liberal como el constitucional colombiano (Botero Marino 2003, 49).
} 
pluralismo jurídico en los años noventa del siglo xx y la plurinacionalidad en el siglo XXI. Asegura también que el gran reto sigue siendo la implementación efectiva de estas reformas.

Visto desde una concepción global, el multiculturalismo tiene como reto reacomodar las diferencias culturales que se evidencian en las sociedades modernas y estructurar los dispositivos jurídicos, sociales y políticos de manera que conduzcan al reconocimiento de la identidad de los diferentes conglomerados humanos que integran una sociedad.

Precisa el investigador Kymlicka $(1996,26)$ que

una fuente de diversidad cultural es la coexistencia, dentro de determinado Estado, de más de una nación, donde 'nación' significa una comunidad histórica, más o menos completa institucionalmente, que ocupa un territorio o una tierra natal determinada y que comparte una lengua y una cultura diferenciadas. La noción de 'nación', en este sentido sociológico, está estrechamente relacionada con la idea de 'pueblo' o de 'cultura'; de hecho, ambos conceptos resultan a menudo intercambiables. Un país que contiene más de una nación no es por tanto una naciónEstado, sino un Estado multinacional, donde las culturas más pequeñas conforman las 'minorías nacionales'.

En este orden de ideas, hay que diferenciar la situación particular de los pueblos indígenas de otras formas de diversidad cultural que ocurren en los Estados. Es importante destacar que los pueblos indígenas canadienses (y también los pueblos indígenas de Suramérica) han adoptado el nombre de primeras naciones y, en este sentido, definen una situación en la que el énfasis de la relación se presenta entre nación-nación. En consecuencia, las relaciones entre estas comunidades y la nación predominante inevitablemente colocan a los primeros en una mejor posición, con pretensión de igualdad, o cuando menos de menor desigualdad (Ibarra 2007,34). Esta aspiración formalizada en el ordenamiento jurídico implica una nueva forma de producción de las normas y de explotación del territorio, ${ }^{14}$ donde los indígenas tienen un papel activo y dinámico que se concreta en los derechos fundamentales al territorio,

\footnotetext{
${ }^{14}$ Iniciamos mencionando que según la visión de los mismos pueblos indígenas "los territorios no son solo un espacio geográfico, como piensan los Estados. Son recursos naturales, es la frontera, es de-
} 
a la consulta previa y en el reconocimiento del consentimiento libre, previo informado. ${ }^{15}$

Para la investigación propuesta, en esta parte haremos referencia a algunas de las discusiones que se han presentado en el contexto internacional sobre la definición del concepto pueblos indígenas y tribales, estableceremos cuáles son los aspectos históricos de la política indígena y diferenciaremos la forma en que cada uno de sus principales derechos se ve afectado por las disputas sociales, económicas y políticas entre los diversos actores.

Se analizarán los principales debates y pronunciamientos de la Corte Constitucional referentes a los derechos indígenas y se señalarán tanto su contenido como sus limitaciones. Adicionalmente, se estudiarán los espacios y mecanismos de participación de los pueblos indígenas y las problemáticas en su implementación. Finalmente, haremos referencia, en el marco del derecho fundamental, a la participación, a las limitaciones y los más relevantes retos en relación con la incidencia de estos pueblos en las decisiones que pueden afectarles.

\subsection{Concepto pueblos indígenas y tribales}

Conviene precisar el término pueblos indígenas antes de iniciar el análisis de sus derechos. La razón es que hay muchas discusiones en el ámbito internacional con respecto a su alcance y a la diferencia que existe entre los conceptos de poblaciones indígenas y comunidades tribales. En consecuencia, consideramos que abordarlas proporciona mayor claridad al tema de estudio.

\subsubsection{Alcance del concepto pueblos}

Por lo general, se considera, como lo afirma James Anaya $(2005,100)$, que el término pueblo implica un mayor conocimiento de la identidad colectiva y los correspondientes atributos de la comunidad. Sin embargo, en las discusiones previas a la adopción del Convenio 169, los gobiernos se resistieron a su uso debido a la asociación del mismo con el término autodeterminación o libre

\footnotetext{
limitación, es la estructura, es la organización, es mucho más, porque todo es integral. Ahí se vive y se convive" (Huanacani Mamani 2010,7).

${ }^{15}$ Art. 32 de la DNUDPI: "2. Los Estados celebrarán consultas y cooperarán de buena fe con los pueblos indígenas interesados por conducto de sus propias instituciones representativas a fin de obtener su consentimiento libre e informado antes de aprobar cualquier proyecto que afecte a sus tierras o territorios y otros recursos, particularmente en relación con el desarrollo, la utilización o la explotación de recursos minerales, hídricos o de otro tipo".
} 
determinación, un principio asociado con el derecho a formar un Estado independiente. La cuestión se hizo en su momento todavía más compleja, debido a que los pueblos indígenas han invocado el derecho a la autodeterminación para expresar su voluntad de continuar existiendo como comunidades diferenciadas y libres de opresión, aunque en la práctica ello no significa necesariamente que tengan aspiraciones de formar sus propios Estados independientes.

Así las cosas, para establecer el alcance de estos términos, es necesario mirar los antecedentes jurídicos internacionales sobre protección de los pueblos indígenas, iniciando por mencionar que la oIT fue el primer organismo internacional que se ocupó de estos asuntos.

Desde su creación en 1919, la oit ha defendido los derechos sociales y económicos de los grupos cuyas costumbres, tradiciones, instituciones o idioma los separan de otros sectores de las comunidades nacionales. En 1953, este organismo publicó un estudio sobre poblaciones indígenas y en 1957 adoptó el Convenio núm. 107 y la Recomendación núm. 104 sobre la protección e integración de las poblaciones indígenas y tribales. Esos fueron los primeros instrumentos jurídicos internacionales creados específicamente para proteger los derechos de las poblaciones cuyos estilos de vida y cuya existencia estaban entonces, como ahora, amenazados por las culturas dominantes. (onu 1998, 22)

E1 Convenio 107 de la oIT sobre poblaciones indígenas y tribales se aprobó en Ginebra en 1957. ${ }^{16}$ Con el pasar del tiempo, en ese organismo, los representantes indígenas y algunos expertos estimaron conveniente modificarlo de modo que hiciera referencia específica a pueblos indígenas y tribales. Consideraban que la palabra pueblo indicaba que dichos grupos humanos tenían identidad propia y reflejaba más adecuadamente la opinión que ellos tenían de sí mismos, mientras que el término poblaciones denotaba sólo una mera agrupación de personas. Señalaron también que varios países ya utilizaban el

\footnotetext{
${ }^{16}$ Este instrumento internacional se encontraba orientado a la asimilación de los pueblos indígenas con fundamento en la suposición subyacente de que el único futuro posible para estos pueblos era su integración en el resto de la sociedad, y que otros habían de tomar decisiones sobre su desarrollo (oIT 2013, 4). El Convenio 107 de la oit fue ratificado en nuestro país mediante la Ley 31 de 1967.
} 
término en sus legislaciones nacionales y que su uso había sido aceptado en debates celebrados en la Organización de las Naciones Unidas - en adelante $\mathrm{ONU}-\mathrm{y}$ en los tribunales internacionales.

Por el contrario, el informe de la reunión de expertos de la OIT muestra que otros participantes estimaron que, precisamente por sus connotaciones, la utilización de este término en un convenio revisado planteaba conflictos. Sin dejar de respetar los deseos de los representantes indígenas a que se les mencionara como pueblos, estimaban que incorporar dicha expresión en un convenio de la oIT podría implicar un grado de reconocimiento de dichos grupos que excedería el ámbito de competencia de esta organización, contradiciendo las prácticas de un gran número de países que, de otro modo, podrían ratificarlo. Por otra parte, concordaban en que este punto contenía una aspiración legítima y merecía una cuidadosa consideración por parte de la conferencia durante la revisión del instrumento.

La preocupación de quienes no deseaban utilizar la palabra pueblos obedecía al temor de que dicho término contempla el reconocimiento de un derecho a cierto grado de autonomía política, inaceptable para muchos Estados. No obstante, la onU (1998, 33-34) estimaba que tal implicación podía evitarse si los debates de la conferencia dejaban bien claro que dicha palabra se utilizaría para reconocer que estos grupos tenían identidad propia y se consideraban a sí mismos como tal, pero que las consecuencias del término deberían fijarse en cada nación y en el contexto interno de los Estados que ratificaran el convenio.

En la práctica de la OIT, ambos términos (pueblos y poblaciones) se utilizaron indistintamente en el pasado; en cambio, en la mayor parte de la documentación de las Naciones Unidas y del llamado Grupo de Trabajo de la oIT se recurría con frecuencia a la expresión pueblos. Igualmente, el relator especial designado por la subcomisión de la onu para hacer un estudio al respecto demostró que existía una preferencia por dicha palabra y que también era de uso corriente en otros escenarios internacionales.

Esta discusión también se presentó en la reunión para la Revisión Parcial del Convenio 107 de la oit, que dio origen al Convenio 169, como se puede constatar en las actas provisionales de la septuagésima sexta reunión de dicha organización, celebrada en Ginebra en 1989. En ellas aparecen los argumentos a favor o en contra de los términos pueblos o poblaciones. En esa ocasión, el secretario general 
observó que, a pesar de las diferencias de opinión, ambas partes estuvieron de acuerdo en que el separatismo político — que el empleo del término 'pueblos' podría implicar- no debería de ninguna forma ser promovido por el convenio. Además, manifestó que ambas partes estuvieron de acuerdo en que las comunidades en cuestión deberían guardar su identidad y no ser reducidas a cifras — peligro que el empleo del término 'poblaciones' conlleva. Como consecuencia, llamó la atención de la Comisión respecto a una fórmula para el artículo 1, párrafo 3 del texto propuesto, la que podría permitir llegar a un acuerdo. (отт 1989, 25/2)

De esa manera, en junio de 1989, después de múltiples discusiones y de cuatro años de labor preparatoria, la Conferencia Internacional del Trabajo aprobó una versión revisada del Convenio 107. De allí surgió el Convenio 169 , que tiene como finalidad asegurar los derechos de los pueblos indígenas y tribales, a la vez que sirve de base para las actividades operacionales y de asistencia técnica de la oIt. En las décadas de los setenta y ochenta del siglo $\mathrm{xx}$ se presentó un proceso de reconocimiento de los pueblos indígenas como actores políticos y como sujetos de derechos (de forma individual y colectiva), lo que se ha dado en llamar como la emergencia indígena, que se trató de un interesante proceso de concienciación por parte de los propios pueblos indígenas, que los convirtió en actores políticos tanto a nivel interno como a nivel internacional, proceso que culminó con el mencionado Convenio 169 de la OIT, el instrumento jurídico internacional más relevante para la protección y promoción de los derechos indígenas (Gómez Isa 2013, 20).

Así las cosas, el Convenio 169 se considera hoy como un instrumento holístico que pretende abordar todos los aspectos claves de los derechos de estas comunidades, relacionadas entre sí. Así mismo, asume temas tales como el que los derechos a la consulta y a la participación son transversales y tienen repercusiones, por ejemplo, sobre los derechos estipulados en sectores como la salud y la educación (огт 2009, 6). Los siguientes países han ratificado el Convenio en mención: 
Tabla 1. Países que han ratificado el Convenio 169 de la ort y fecha de ratificación

\begin{tabular}{|l|c|}
\hline \multicolumn{1}{|c|}{ País } & Fecha \\
\hline Argentina & 3 julio 2000 \\
\hline Bolivia, Estado Plurinacional de & 11 diciembre 1991 \\
\hline Brasil & 25 julio 2002 \\
\hline Centroafricana, República & 30 agosto 2010 \\
\hline Chile & 15 septiembre 2008 \\
\hline Colombia & 4 marzo de 1991 \\
\hline Costa Rica & 2 abril 1993 \\
\hline Dinamarca & 22 febrero 1996 \\
\hline Dominica & 25 junio 2002 \\
\hline Ecuador & 15 mayo 1998 \\
\hline España & 15 febrero 2007 \\
\hline Fiji & 3 marzo 1998 \\
\hline Guatemala & 5 junio 1996 \\
\hline Honduras & 28 marzo 1995 \\
\hline México & 5 septiembre 1990 \\
\hline Nepal & 14 septiembre 2007 \\
\hline Nicaragua & 25 agosto 2010 \\
\hline Noruega & 19 junio 1990 \\
\hline Países Bajos & 2 febrero 1998 \\
\hline Paraguay & 10 agosto 1993 \\
\hline Perú & 2 febrero 1994 \\
\hline Venezuela, República Bolivariana de & 22 mayo 2002 \\
\hline
\end{tabular}

Fuente: OIT (1989).

Como resultado del debate, el parágrafo 3 del artículo $1^{\circ}$ del Convenio 169 de la oIT explica que el término pueblo no deberá interpretarse, señalando que tiene alguna implicación en lo que atañe a los derechos que puedan conferirse a dicho término en el derecho internacional. Asimismo, se acordó incluir el siguiente texto en las actas de la comisión encargada de la elaboración: “Queda entendido para la Comisión que el empleo del término 'pueblos' en este convenio no tiene implicaciones respecto del derecho a la autodeterminación tal como se entiende en el derecho internacional" (Anaya 2005,101).

Antes de finalizar la disertación sobre el término pueblo, debemos hacer un paréntesis para señalar que en el seno la ONU se dio un debate similar sobre su utilización, cuando se discutía la adopción de la DNUDPI. El artículo 46 
aclara su alcance al consagrar que nada de lo señalado en la declaración se interpretaría en el sentido de que confiere a un Estado, pueblo, grupo o persona derecho alguno a participar en una actividad o realizar un acto contrario a la Carta de las Naciones Unidas y que no se entendería en el sentido de que autoriza o fomenta acción alguna encaminada a quebrantar o menoscabar, total o parcialmente, la integridad territorial o la unidad política de Estados soberanos e independientes. A continuación mencionaremos las diferencias básicas entre los Convenios 107 y 169 de la OIT.

Tabla 2. Comparación entre los Convenios 107 de 1957 y 169 de 1989 de la oIT

\begin{tabular}{|l|l|}
\hline \multicolumn{1}{|c|}{ Número 107 (1957) } & \multicolumn{1}{c|}{ Número 169(1989) } \\
\hline $\begin{array}{l}\text { Se basa en la idea de que las poblaciones indígenas } \\
\text { y tribales eran sociedades temporales que } \\
\text { estaban destinadas a desaparecer por efecto de la } \\
\text { modernización. }\end{array}$ & $\begin{array}{l}\text { Se basa en la idea de que los pueblos indígenas y } \\
\text { tribales son sociedades permanentes. }\end{array}$ \\
\hline Habla de poblaciones. & Habla de pueblos. \\
\hline $\begin{array}{l}\text { Propicia la asimilación de los pueblos indígenas y } \\
\text { tribales a la sociedad dominante. }\end{array}$ & $\begin{array}{l}\text { Propicia el establecimiento de una nueva relación } \\
\text { entre el Estado y los pueblos indígenas y tribales, } \\
\text { basada en el reconocimiento de la diversidad } \\
\text { cultural y étnica. }\end{array}$ \\
\hline $\begin{array}{l}\text { La asimilación implica proteger a los } \\
\text { pueblos indígenas durante su transición a la } \\
\text { modernización. }\end{array}$ & $\begin{array}{l}\text { La nueva relación implica, además, otorgar una } \\
\text { protección a los pueblos indígenas y tribales } \\
\text { e impulsarlos a que establezcan sus propias } \\
\text { prioridades de desarrollo. }\end{array}$ \\
\hline
\end{tabular}

Fuente: DGAI, DGN, Ecopetrol, UPME, MMA $(1999,10)$.

Al tener en cuenta lo anterior, se puede evidenciar que durante el siglo $\mathrm{xx}$ se presentaron avances significativos en la estructura de la organización mundial, al tiempo que se produjeron cambios en las concepciones normativas asociadas a la misma. Estos cambios han generado reformas en el sistema jurídico internacional y han proporcionado a las fuerzas sociales la oportunidad de influir y/o alterar la dirección del derecho internacional en aspectos relacionados con los pueblos indígenas (Anaya 2005, 77).

El Convenio 107 respondió a las políticas de asimilación buscando, como lo plantea el profesor Anaya $(2005,89)$, atraer al redil del autogobierno a los grupos indígenas en procura de la promoción de mejores condiciones sociales y económicas en general; por su parte, el Convenio 169 atiende a las demandas de los pueblos indígenas y, en consecuencia, desde su preámbulo 
responde a las aspiraciones de dichos pueblos de asumir el control de sus propias instituciones, formas de vida y su desarrollo económico y a mantener y fortalecer sus identidades, lenguas y religiones, dentro del marco de los Estados que habitan. El primero responde a objetivos individualistas de protección contra la discriminación y las prácticas de explotación, mientras el segundo busca eliminar, reconociendo la evolución del derecho internacional y los cambios sobrevenidos en la situación de los pueblos indígenas, la orientación hacia la asimilación de las normas anteriores.

En este escenario, el Convenio 169 implica avanzar en estrategias para superar la asimilación y la integración de los pueblos indígenas que primaron desde la época de la colonia. Así, el derecho internacional tiene el reto de desarrollarse para que se garanticen sus disposiciones sobre integridad cultural, no discriminación, bienestar social, participación y consulta previa, no obstante las limitaciones que se derivan de la diversidad de intereses en relación con los territorios y los recursos que han manejado estas colectividades.

Fraser $(1997,18)$ plantea que las luchas por el reconocimiento tienen lugar en un mundo de exageradas desigualdades materiales en cuanto a ingresos y propiedad. Vista así las cosas, este convenio puede entenderse como una manifestación de mayor reconocimiento de las demandas del movimiento indígena mediante el derecho internacional y, simultáneamente, de las tensiones inherentes a este movimiento. Los pueblos indígenas han reclamado el reconocimiento del derecho de carácter colectivo, que tiene como beneficiarias a comunidades de raigambre histórica, y no ya a los individuos o a los Estados. La conceptualización y articulación de dicho derecho se enfrenta con la dicotomía individuo/Estado que perdura en las concepciones dominantes sobre la sociedad e influye en la elaboración de estándares internacionales (Anaya 2005, 99).

\subsubsection{Pueblos indígenas y tribales}

De acuerdo con lo anterior, la mejor manera de solucionar los problemas planteados con respecto al término pueblos fue dejar claro que en el Convenio 169 de la oit la expresión pueblo indígena no implica lo que comúnmente podría implicar en el derecho internacional. Este instrumento internacional no impone ninguna limitación al derecho a la autodeterminación de los pueblos indígenas, ni tampoco se pronuncia a favor o en contra de él. La guía para la aplicación del mencionado convenio asegura que el término indígena se refiere 
a aquellas poblaciones que conservan total o parcialmente sus propias tradiciones, instituciones o estilos de vida que los distinguen de la sociedad dominante y que habitaban un área específica antes de la llegada de otros grupos.

Según el artículo $1^{\circ}$ del mencionado convenio, este instrumento se aplica a los pueblos indígenas, estableciendo para su consideración los siguientes elementos (оіт 2009, 9):
a) La continuidad histórica, es decir, que son sociedades anteriores a la conquista o a la colonización.
b) La conexión territorial, lo que significa que sus ancestros habitaban en el país o región correspondiente.
c) Las instituciones políticas, culturales, económicas y sociales distin- tivas que retienen algunas o todas sus instituciones propias.

Por otro lado, como se ha mencionado, el Convenio 169 también habla del término pueblos tribales. Los elementos para la consideración de los pueblos tribales incluyen (oIT 2009, 9):

a) Condiciones económicas, culturales, organización social y forma de vida que los distingan de los otros segmentos de la población nacional, como por ejemplo en la forma de ganarse el sustento, el idioma, etc.

b) Tener tradiciones y costumbres y/o un reconocimiento legal especial.

Reitera el convenio que la conciencia de identidad indígena o tribal deberá considerarse como un criterio fundamental para determinar los grupos a los que se aplican sus disposiciones. En esa forma, la declaración de cobertura del convenio incluye los elementos principales referidos a dicha conciencia de identidad y al vínculo histórico con territorios ancestrales, instituciones culturales, económicas, sociales y con políticas distintivas.

En síntesis, existen unos criterios objetivos y subjetivos para establecer si un pueblo es indígena o tribal y si cumple con los requisitos de aplicación y, además, si se reconoce y acepta a una persona como perteneciente a ese pueblo. Estos criterios son mencionados de manera concreta en la siguiente tabla: 
Tabla 3. Criterios para la aplicación del Convenio 169 de la oIT

\begin{tabular}{|c|l|l|}
\hline Pueblo & \multicolumn{1}{|c|}{ Criterios objetivos } & \multicolumn{1}{c|}{ Criterio subjetivo } \\
\hline Indígena & $\begin{array}{l}\text { - Continuidad histórica } \\
\text { - Conexión territorial } \\
\text { - Instituciones políticas, culturales, } \\
\text { económicas y sociales distintivas }\end{array}$ & - Auto-identificación \\
\hline \multirow{3}{*}{ Tribal } & $\begin{array}{l}\text { Condiciones económicas, culturales, } \\
\text { organización social y forma de vida que } \\
\text { lo distingan; } \\
\text { Tradiciones y costumbres y/o un } \\
\text { reconocimiento legal especial }\end{array}$ & $\begin{array}{l}\text { - Auto-identificación } \\
\text { Conciencia de su identidad }\end{array}$ \\
\hline
\end{tabular}

Fuente: OIT, Convenio 169. Elaboración de la autora.

Hechas estas aclaraciones, debemos mencionar que los pueblos indígenas y tribales del mundo corresponden al menos a cinco mil (5000) comunidades con características distintivas y a una población de más de 370 millones de personas, que habitan en 70 países en todas las regiones del mundo (огт 2013, xi). Estos se ven afectados porque aún continúa su explotación cultural con el turismo en sus territorios, la comercialización de su arte, el aprovechamiento de sus conocimientos tradicionales y de su experiencia en materia de agricultura y de ordenación del ambiente (onu 1998, 3).

En Colombia, dichas afectaciones se dan principalmente como consecuencia del conflicto armado, el desplazamiento, la destrucción de los recursos naturales y hábitats, el impulso de proyectos de infraestructura y de explotación de minerales y de hidrocarburos, entre otros factores. A pesar de ello, los pueblos indígenas han conservado sus características sociales, culturales, económicas y políticas, que son manifestaciones distintas a las de los demás sectores de la población.

Mediante la DNUDPI, ${ }^{17}$ se ha manifestado la preocupación por el hecho de que los pueblos indígenas han sufrido injusticias históricas, como resultado, entre otras cosas, de la colonización y la enajenación de sus tierras, territorios

${ }^{17}$ James Anaya (2013) destaca que dentro de la doctrina generalmente aceptada sobre el derecho internacional, la declaración sobre los derechos de los pueblos indígenas, siendo una resolución de la Asamblea General de la onu y no un tratado, no es una fuente primaria de obligaciones dentro del derecho internacional. Sin embargo, es indudablemente un instrumento dotado de autoridad, y sus disposiciones se fundamentan en principios generales de derechos humanos sentados en la Carta de las Naciones Unidas y en otros tratados que han sido ampliamente ratificados por los Estados. 
y recursos, lo que les ha impedido ejercer su derecho al desarrollo de conformidad con sus propias necesidades e intereses (onu 2007a).

Es útil mencionar en este punto que el ordenamiento jurídico colombiano habla de comunidad o parcialidad indígena, considerada como el grupo o conjunto de familias de ascendencia amerindia que tienen conciencia de identidad y comparten valores, rasgos, usos o costumbres de su cultura, así como formas de gobierno, gestión, control social o sistemas normativos propios que la distinguen de otras comunidades, tengan o no títulos de propiedad, o que no puedan acreditarlos legalmente, o cuyos resguardos hayan sido disueltos, divididos o declarados vacantes (artículo 2, Decreto 2164 de 1995). Igualmente, tanto la Constitución Política de Colombia como la Ley 160 de 1994 hacen referencia al término comunidad indígena. Es decir, la legislación colombiana no utiliza el término pueblo indígena contenido en el Convenio 169 de la oIT.

\subsection{Los pueblos indígenas de Colombia}

Tanto los documentos oficiales como las normas existentes usan de manera reiterada el término comunidades indígenas. ${ }^{18}$ Sin embargo, este documento hablará de pueblos indígenas como una expresión que comprende a las comunidades que estaban viviendo en sus tierras antes de que llegaran los colonizadores españoles y que hoy se representan en los descendientes de las personas que habitaban en el país en el momento en el que arribaron poblaciones de culturas y orígenes étnicos diferentes, que se autoreconocen y cuentan con una identidad propia.

Las afectaciones o los cambios culturales ocurridos en los pueblos indígenas de Colombia comenzaron con la llegada de los españoles en el siglo xv. A partir de entonces, se inició la sustracción de las tierras que desde tiempos ancestrales poseían, la explotación de los recursos naturales que habían conservado y la pérdida de sus conocimientos tradicionales y de su cultura,

\footnotetext{
18 Según el Decreto 2164 de 1995, se entiende por comunidad indígena, "el grupo o conjunto de familias de ascendencia amerindia, que tienen conciencia de identidad y comparten valores, rasgos, usos o costumbres de su cultura, así como formas de gobierno, gestión, control social o sistemas normativos propios que la distinguen de otras comunidades, tengan o no títulos de propiedad, o que no puedan acreditarlos legalmente, o que sus resguardos fueron disueltos, divididos o declarados vacantes”. Debemos aclarar que en este trabajo trataremos de hacer mención siempre al término pueblos indígenas, como se establece en el orden internacional.
} 
manifiesta en las formas de autogobierno que poseían, sus propios idiomas, normas y tradiciones.

Sólo hasta finales del siglo xIx comenzaron a visibilizarse los problemas del territorio y empezó a buscárseles solución. Esto ocurrió cuando se dividieron los resguardos ${ }^{19}$ en todas las regiones del país. Mediante la Ley 89 de 1890, el gobierno replanteó parcialmente su política frente a los resguardos y reconoció la particularidad del derecho y del gobierno indígena.

Sobre ese particular, asegura el profesor Gómez $(1991,1)$ que el avance de una economía primaria y exportadora, tanto en el país como en casi toda Latinoamérica, significó la transformación del pacto colonial por uno nuevo, que se tradujo en una colonización interna de regiones de frontera. En algunos casos, señala, se trataba de zonas vacías que sobrevivieron a la invasión europea de períodos anteriores.

Con este panorama inicial, pasamos a referirnos a las fases históricas de las políticas indígenas de Colombia que se asumen a continuación.

\subsection{Fases históricas de las políticas indígenas}

El investigador Roque Roldán Ortega $(2000,7)$ asegura que puede hablarse de tres grandes fases históricas anteriores a la adopción del Primer Convenio Internacional sobre Indígenas (Convenio 107 de 1957): la conquista, la colonia y la república, que va hasta los primeros años de la década del sesenta en el siglo xx. En este trabajo haremos referencia a una cuarta fase, la del pluralismo y el multiculturalismo, vigente en nuestro país a partir de la promulgación en 1991 de una nueva Constitución Política, de la ratificación del Convenio 169 de la oit y de la DNUDPI.

\subsubsection{La conquista}

La conquista española se inició en los primeros años del siglo XVI, época que representó un impacto catastrófico sobre los primitivos habitantes del continente. Los españoles, según Roldán Ortega (2000, 8), no respetaron ni se sometieron a ningún principio de orden jurídico e impusieron su dominio

${ }^{19}$ Figura jurídica que representa los territorios indígenas que tienen título de propiedad colectiva reconocida por el Estado; tienen como características esenciales su manejo y gobierno interno que corresponde a las autoridades propias de los indígenas y además son inembargables, inalienables e imprescriptibles. 
apoyándose en sus armas de guerra y en la pretendida superioridad de sus formas de vida, de la raza a la que pertenecían, de sus formas de gobierno y de su religión.

La relación estructural de subordinación del indígena que nació a partir de allí tenía como eje un saber religioso meticulosamente construido a partir de una dialéctica de diferencias culturales, y con base en un examen minucioso de la personalidad del indígena americano, su subjetivización ${ }^{20}$ como siervo natural o incapaz mental, como débil e inferior, como un eterno niño sin edad, que justificó la mayoría de las instituciones que moldearon las relaciones entre las comunidades autóctonas y los españoles. La imagen del indígena así construida llegó a aceptarse como algo natural e inherente. Este saber de origen religioso cumplió un papel determinante para justificar las formas de dominación prevalentes del momento, bien sea la dominación personal del encomendero o la espiritual del misionero, cuyo marco estructurante será el derecho indiano ${ }^{21}$ (Ariza 2009, 94).

Desde un primer momento se unieron el compromiso de propagar el cristianismo, sobre la base de los criterios proteccionistas de la legislación indiana, con el llamado descubrimiento y la conquista.

Tratar de la evangelización y de la conquista supone, ante todo, plantearse la relación que la política cristianizadora guarda con la penetración castellana en las sociedades aborígenes, aspecto éste que conduce necesariamente a tomar como punto de partida la utilización del requerimiento como instrumento que facultaría para aquella penetración y consiguiente conquista en el supuesto de rechazo por parte de las comunidades indígenas. (Sánchez Bella, De la Hera, Díaz Rementería 1992,69)

\footnotetext{
${ }^{20}$ Teniendo en cuenta las condiciones reales, podría de manera más adecuada hablarse de "objetivización", dado que así fueron considerados en esos tiempos los pueblos indígenas.

${ }^{21}$ Se entiende por derecho indiano el conjunto de leyes y disposiciones promulgadas tanto por los reyes como por las demás autoridades subordinadas a ellos —residentes en España o en Américacon el objeto de establecer un régimen jurídico especial para las Indias. En sentido amplio, sin embargo, hay que considerar como elementos integrantes del derecho indiano no sólo las normas especiales distadas para las Indias, sino también a las castellanas que, por imperativo legal, se aplicaron en América (Mayorga García 2003, 213).
} 
Considera el profesor Pineda Camacho $(1995,3)$ que, al momento de la conquista, el territorio colombiano estaba habitado por una multiplicidad de culturas con diferentes lenguas y formas de organización social en relación con el medio ambiente. Estas sociedades formaban parte de largas tradiciones regionales que paulatinamente forjaron su propia identidad socio-cultural, no obstante los diversos procesos de intercambio e interacción económica, social y simbólica. El total de la población indígena existente en el momento de la conquista española se ha estimado entre 6000000 y 10000000 de habitantes. Sin embargo, los indígenas fueron afectados por el régimen colonial, ya fuera por la intromisión en su organización política y social o por las enfermedades que terminaron por generar la muerte de muchos de ellos. Adicionalmente, esta situación generó el desplazamiento de sus territorios, la guerra y la alteración de sus formas de vida.

\subsubsection{La colonia}

La fase colonial cubre un larguísimo período de casi tres siglos y coexistió con la fase de la conquista durante buena parte del siglo xvi. Para Roldán, la escandalosa y dramática desaparición física, apenas 50 años después del desembarco español, de una abrumadora mayoría de la población que habitaba los territorios americanos, llevó a los monarcas a expedir innumerables leyes que por diversos medios intentaban poner término al genocidio y controlar los abusos y arbitrariedades de sus compatriotas. Estimaba la corona española, con sobradas razones, que de continuar el proceso de exterminio y aniquilamiento la obra misma de la colonización se frustraría, por falta de apoyo humano para la construcción de un sistema económico, político y social que podría ser anexado a sus territorios y que duplicaba en extensión al continente europeo (Roldán Ortega 2000, 9-10).

Aparece entonces la legislación de indias, indiana o derecho indiano, que corresponde al conjunto de la legislación de España en América, la cual fue muy abundante y se constituye en fuente de la legislación indígena colombiana aplicada actualmente. Para el profesor Mayorga García (2003,136-139), el derecho indiano estaba constituido por un conjunto de nuevas disposiciones que regularon la vida novomundana, inspirándose ya en los principios o normas del antiguo derecho común, ya en los del castellano, y perfilándose desde sus orígenes como una construcción que enlazaba la tradición jurídica medieval 
con el espíritu renacentista, tan propio de la empresa del descubrimiento y la colonización del Nuevo Mundo.

El derecho indiano propiamente dicho se componía de: (1) las normas sancionadas en España para regular el funcionamiento de los órganos gubernamentales indianos allí existentes; (2) las leyes expedidas en España para resolver los problemas de América hispánica y Filipinas; (3) las leyes y costumbres establecidas en Indias; (4) las interpretaciones de todas esas leyes hechas por los tribunales superiores (Consejo de Indias y audiencias). Así las cosas, el derecho indiano provenía de múltiples autoridades e, incluso, era a veces consuetudinario.

En la época de la colonia, los conflictos que se presentaban entre indígenas y españoles se resolvían con la legislación indiana y tenían como objetivo proteger a los indígenas del poder encomendero. Por su parte, la resolución de la mayoría de los conflictos menores entre indígenas se delegaba a las autoridades tradicionales. Internamente, dentro del espacio de la reducción, se aceptó la vigencia de 'los usos y costumbres' indígenas, los cuales serían incorporados al derecho indiano como derecho consuetudinario (Ariza 2009,109).

Por otro lado, dos instituciones, el resguardo y el cabildo indígena (sobre las que van a girar las diferentes disposiciones, que desde la época del libertador se han expedido hasta el presente) aparecieron durante la colonia, pero se heredaron de la Corona española. Los pueblos indígenas, en un justificado afán por encontrar el mecanismo de defensa para sus ancestrales territorios, hicieron suyas dichas instituciones que prevalecen hasta el presente (Colombia, Caja Agraria, Incora, Inderena y División Operativa de Asuntos Indígenas 1990,15). Durante esta fase, las cédulas reales reconocieron la ocupación histórica sobre título originario de propiedad territorial indígena en América, que no necesitaba validarse con títulos formales; el derecho de los pueblos indígenas a conservar sus autoridades y gobierno propio; los resguardos indígenas como forma de propiedad territorial; además, se impusieron instituciones para la explotación del trabajo indígena como fueron la encomienda para el trabajo agrícola y la mita para la explotación minera (oNic 2007a,23).

\subsubsection{La república}

En la tercera fase planteada por Roldán Ortega, el propósito que más se reiteraba en leyes y programas de gobierno era el de alcanzar la pronta asimilación de los indígenas colombianos al modelo de vida económica, social, política, religiosa y cultural de la mayoría de la sociedad nacional. 
En su oportunidad, Simón Bolívar expidió el Decreto del 5 de julio de 1820, sobre la devolución a los naturales de todas las tierras que formaban parte de los resguardos, como un reconocimiento de las luchas por la independencia de España. Adicionalmente, se otorgó el derecho de tener autoridades y gobierno propio; se exoneró del pago de impuestos sobre las tierras de los resguardos y del servicio militar.

Posteriormente, se expidió la Ley 89 de 1890, mediante la cual el gobierno central replanteó parcialmente su política frente a los resguardos indígenas. Con esta norma, se reconoció la particularidad del derecho y del gobierno indígena y se estableció la manera como debían ser gobernados los 'salvajes'22 que fuesen reduciéndose a la vida civilizada. Además, se fijaron unos parámetros supuestamente para la defensa de los indígenas: estabilidad en cuanto a la propiedad de sus tierras, vida legal a los cabildos como entes relativamente autónomos representativos de las comunidades, etc.

Menciona el profesor Ariza $(2009,203)$ que el resguardo, sus principios y funcionamiento fueron articulados definitivamente por la mencionada Ley 89 de 1890 y, como dispositivo de control y protección de la población indígena, gozaría de una estabilidad que pocas instituciones han alcanzado en Colombia. Los indígenas estaban atados al resguardo porque, aparentemente, sólo allí podían existir. De este modo, se establece una relación esencial entre el espacio y la existencia del sujeto, entre un dispositivo y la identidad de los sujetos que son su objetivo.

Posteriormente, a comienzos del siglo xx fueron aprobadas otras normas con marcada tendencia a la liquidación de los resguardos que habían sido constituidos. ${ }^{23}$ En estos tiempos la situación era compleja debido a la expedición

${ }^{22}$ Sólo hasta 1996, más de 100 años después de la expedición de la Ley 89 de 1890, la Corte Constitucional colombiana declaró inexequible el término "salvaje". En la providencia señala que "la terminología utilizada en el texto, al referirse a 'salvajes' y 'reducción a la civilización' desconoce tanto la dignidad de los miembros de las comunidades indígenas como el valor fundamental de la diversidad étnica y cultural. Una concepción pluralista de las relaciones interculturales, como la adoptada por la Constitución de 1991, rechaza la idea de dominación implícita en las tendencias integracionistas. Aunque se puede entender que los términos del artículo acusado han sido derogados tácitamente por las nuevas leyes que regulan la materia (ver. Convenio 169 de la oIT, que habla de 'pueblos indígenas y tribales') y, sobre todo, por la Constitución de 1991, no encuentra la Corte ninguna razón para mantener en vigencia el artículo acusado, como quiera que su significado, independientemente de los términos en que se expresa, es contrario a la Constitución" (ccc, C-139/96).

${ }^{23}$ Entre ellas, la mencionada Ley 55 de 1905, 51 de 1911, 106 de 1913 y 19 de 1927. 
de la Ley 55 de 1905, que ratificaba y confirmaba la declaración judicial y legal de estar vacantes globos de terreno conocidos como resguardos indígenas. Las ventas de estas tierras eran efectuadas en subasta pública, reconociendo como título legal de propiedad de los terrenos de resguardos el adquirido por sus rematadores (Arango Ochoa y Sánchez Gutiérrez 2004, 19).

Así aparece a principios del siglo xx Manuel Quintín Lame y su lucha, ${ }^{24}$ que, según Gros $(1991,179)$, puede interpretarse como la reacción brutal y desesperada de una población indígena directamente atacada en sus tierras por un impulso capitalista sin precedentes (y sin futuro inmediato): deforestación masiva, introducción de la ganadería y del café, imposición del trabajo forzado, etc. ${ }^{25}$ Consideramos importante mencionar que este se constituye en el más importante líder, ${ }^{26}$ quien en su momento sostenía: "yo no soy profeta pero sí he sido y soy el apóstol de mi raza” (onic 2007b, 8).

Por tanto, asegura el investigador Naranjo Peña $(2012,152)$, el campo del discurso de Quintín Lame (figura 1), cuyo referente central giró en torno a la asunción de la raza indígena o guananí, se constituyó con la presencia de múltiples elementos como la religión católica, la cosmovisión indígena, la educación y el derecho, que desde diversas perspectivas colmaron de sentido el contenido de este punto central utilizado para argumentar las reivindicaciones de los indígenas.

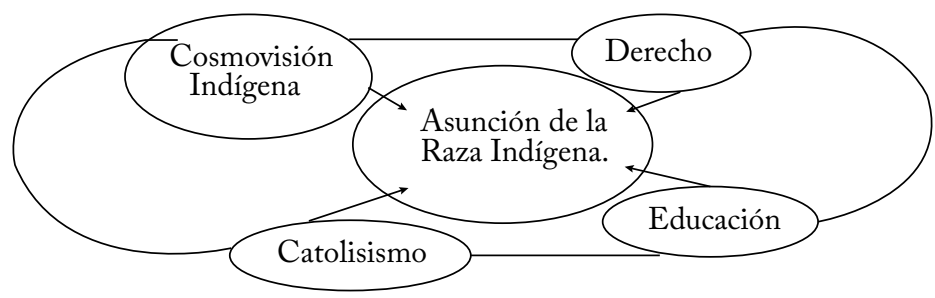

Figura 1. Constitución del campo discursivo en la obra de Manuel Quintín Lame Fuente: Naranjo Peña $(2012,153)$.

${ }^{24}$ Para ahondar en el debate se sugiere ver: Lame (1973); Gros (1991), Fajardo Sánchez (1999); Vega Cantor (2002), Espinosa Arango (2009), entre otros.

${ }^{25}$ Otro personaje importante de esta lucha fue José Gonzalo Sánchez, lugarteniente de Manuel Quintín Lame, cuyo trabajo por el territorio se realizó en el Cauca y en el Tolima.

${ }^{26}$ Eso es evidente en regiones como el Cauca, donde se presenta una historia larga de resistencia, sostenida por una sociedad indígena y por un pueblo que, palmo a palmo, ha defendido su territorio, su autonomía, sus modos de vida y su cultura (Gros 1991,179). 
Quintín Lame fue conocido como "el gran cacique de todos los indios". Fue quien promovió un movimiento social contra los hacendados, conocido como "la quintiada", uno de cuyos hechos destacados sucedió en el año 1914, cuando planeó un levantamiento en Cauca, Huila, Tolima y Valle para constituir una república indígena. Por su resistencia, este líder estuvo arrestado 150 veces, lo que significó pasar 18 años, 7 meses y 21 días en las cárceles colombianas. Pero con su arduo trabajo revitalizó la lucha ancestral por la tierra y la cultura (onic 2007b, 10). Manuel Quintín Lame fue el líder de las luchas surgidas por las precarias condiciones que vivían los indígenas durante los primeros años del siglo anterior y hasta su muerte en 1967. Esas luchas encontraron sustento en la Ley 89 de 1890, que fue su bandera.

Más adelante, nacieron otras formas organizativas propias de los pueblos indígenas, al calor de hechos significativos del orden nacional e internacional, como la Convención Internacional de Pázcuaro (1940), la suscripción del Convenio 107 de la OIT sobre protección e integración de las poblaciones indígenas y tribales en los países independientes, la creación en Colombia de la División de Asuntos Indígenas del Ministerio de Gobierno, del Instituto Colombiano de Antropología, del Instituto Colombiano de Reforma Agraria y las luchas agrarias. En los años setenta comienzan a tomar fuerza las organizaciones propiamente indígenas, luego de que sus comunidades se separaron de la Asociación Nacional de Usuarios Campesinos (ANUc), que lideraba el movimiento de reivindicación de tierras en Colombia.

Evidentemente, desde finales de la pasada década del sesenta y comienzos de los años setenta hubo una ola de movilización indígena en América Latina que se reflejó en nuestro país. A partir de 1971 hubo procesos organizativos y se dio forma a un movimiento relativamente unificado, mediante el cual los indígenas expresan sus reivindicaciones de manera directa. De esta forma, adquirieron mayor visibilidad y organización (Benavides Vanegas 2013,22) y surge así el Consejo Regional Indígena del Cauca (CRIC), creado en 1970, que empieza y lidera este proceso en Colombia con un programa inspirado por Manuel Quintín Lame. Por medio de este, promueve la lucha por la recuperación de la tierra, la lengua y la cultura. Su propósito era exigir la devolución de tierras usurpadas por los hacendados, el respeto por los cabildos indígenas y la abolición de todas las formas serviles de contratación (Roldán Ortega 2000,76). 
El CRIC ${ }^{27}$ sirvió de ejemplo para incentivar la creación de nuevas asociaciones como la Organización Nacional Indígena de Colombia, onic. Entre sus objetivos están la reconstitución de sus territorios, el fomento y la consolidación de las autoridades tradicionales, la implementación de programas de salud, educación y producción, la "defensa de la cultura"28 y el acceso a un desarrollo adaptado a sus condiciones (Laurent 2005,74).

La bandera principal del cRIC es la lucha por la propiedad de la tierra, por la que estas nuevas formas organizativas y de gobierno propio encuentran en el territorio la posibilidad de garantizar la existencia de una identidad cultural. "Dada la configuración de organizaciones sociales y de órganos estatales especializados para la concertación de la política indigenista, la década de 1980 parece entonces representar el período de institucionalización de la cuestión indígena” (Santamaría 2008, 112).

Teniendo en cuenta los argumentos previamente mencionados, se puede establecer a continuación los puntos concomitantes entre el programa político de Manuel Quintín Lame y el cric:

Tabla 4. Comparación entre la propuesta política de Manuel Quintín Lame y la propuesta del CRIC

\begin{tabular}{|c|l|l|}
\hline & \multicolumn{1}{|c|}{ Programa político de Manuel Quintín Lame } & \multicolumn{1}{c|}{ Primer programa político del cRIC } \\
\hline 1 & $\begin{array}{l}\text { Defender las parcialidades indígenas y } \\
\text { resguardos. }\end{array}$ & Ampliar los resguardos. \\
\hline 2 & Rechazar las leyes de extinción de los resguardos. & Hacer conocer las leyes propias. \\
\hline 3 & No pagar terraje. & No pagar terraje. \\
\hline 4 & $\begin{array}{l}\text { Reconocer a los cabildos indígenas como centros } \\
\text { de autoridad. }\end{array}$ & Fortalecer los cabildos. \\
\hline 5 & $\begin{array}{l}\text { Recuperar las tierras usurpadas por los terrate- } \\
\text { nientes y desconocer todos los títulos que no se } \\
\text { basen en cédulas reales. }\end{array}$ & Recuperar las tierras de los resguardos. \\
\hline 6 & $\begin{array}{l}\text { Condenar y rechazar la discriminación racial a la } \\
\text { que están sometidos los indios colombianos. }\end{array}$ & Defender la historia. \\
\hline 7 & \multicolumn{2}{|l}{} \\
\hline
\end{tabular}

Fuente: Naranjo Peña $(2012,157)$.

\footnotetext{
${ }^{27}$ Para profundizar en el debate, se sugiere ver además Archila y González (2010).

${ }^{28}$ Rappaport $(2008,24)$ señala que la cultura en la interculturalidad del CRIC no proviene de la antropología modernista, sino de un imaginario político en el que la cultura es un vehículo para negociar la diversidad y, en consecuencia, está siempre en movimiento.
} 
Estos procesos de lucha por el territorio y los derechos de los pueblos indígenas, además de la aprobación del Convenio 169, propiciaron el camino para que se diera la participación de representantes indígenas en la Asamblea Constituyente de 1991. Evidentemente, aunque los indígenas colombianos son el 3\% del total de la población, la dinámica de sus protestas y el repertorio de sus acciones colectivas, especialmente en el departamento de Cauca, muestran la intención de convertirse en un actor sociopolítico clave de nuestra sociedad (Archila Neira 2012,326), cuyos resultados se reflejan en la fase del multiculturalismo con la consagración de los derechos y las luchas en defensa de los mismos.

\subsubsection{Multiculturalismo y pluralismo jurídico en Colombia}

En Colombia puede hablarse de otra fase histórica relacionada con las políticas indígenas a partir del año 1991, cuando se expidió la nueva Constitución Política, se ratificó el Convenio 169 y se discutió la DNudPi. Esta fase comienza veinte años después de que empiezan a organizarse los movimientos indígenas, cuando tres de sus representantes hicieron parte de la Asamblea Nacional Constituyente, convocada, de manera excepcional, para construir una nueva Constitución Política en el país (Laurent 2005,31). En esta etapa, los derechos de los pueblos indígenas cobran gran relevancia porque fueron reconocidos en dos instrumentos jurídicos y en una norma soft law. ${ }^{29}$

Por primera vez, una Carta Política colombiana se refiere a los indígenas indicando que en el país se reconoce y protege la diversidad étnica y cultural y consagrando la obligación del Estado y de todas las personas de proteger las riquezas naturales y culturales de nuestra nación. Desde el primer artículo, la Constitución define que Colombia es un Estado social de derecho, democrático, participativo y pluralista, donde se prohíbe la discriminación por razones de raza u origen. Además, promueve las condiciones para que la igualdad sea real y efectiva, adoptando medidas en favor de grupos discriminados o marginados, como son los pueblos indígenas.

${ }^{29}$ Soft law significa 'derecho suave'. Se trata de prescripciones cuyas características son diferentes a las propias de las normas legales internacionales, pero producen ciertos efectos. Sirven de parámetros de interpretación para ampliar el corpus iuris internacional en materia de derechos humanos (art. 29, Convención Americana de Derechos Humanos). 
De esta forma, en concordancia con el Convenio 169, el Estado debe adoptar medidas acordes con las tradiciones y culturas de los pueblos indígenas, con el fin de darles a conocer sus derechos y obligaciones. Adicionalmente, en la búsqueda de su protección y de garantizar el respeto de su integridad, se debe asumir la responsabilidad de desarrollar una acción coordinada y sistemática, incluyendo medidas que aseguren que dichos pueblos gocen de los derechos y oportunidades otorgadas al resto de la población (Convenio 169 de la OIT). En cumplimiento de estos preceptos, el Estado debe promover la efectividad de sus derechos sociales, económicos y culturales y eliminar las diferencias socioeconómicas de una manera compatible con sus aspiraciones $\mathrm{y}$ formas de vida.

A lo anterior se agrega que, después de un largo período de discusión en el seno de Naciones Unidas, los pueblos indígenas de todo el mundo ven el reconocimiento de sus derechos en un nuevo instrumento de máxima relevancia internacional: la Declaración de Naciones Unidas sobre los Derechos de los Pueblos Indígenas (DNUDPI). Para el ex relator especial sobre la Situación de los Derechos Humanos y Libertades Fundamentales de los Indígenas, James Anaya, esta declaración representa un entendimiento común fehaciente, en el plano global, del contenido mínimo de los derechos de los pueblos indígenas, que se fundamenta en diversas fuentes de normas internacionales de derechos humanos y que refleja normas de aplicación general y a la vez las enriquece, según se interpretan y aplican por los órganos establecidos en virtud de tratados regionales y de las Naciones Unidas, así como las normas establecidas por el Convenio 169 de la OIT y por otros instrumentos y procesos pertinentes (Anaya 2008, 31).

El presidente del Foro Permanente para las Cuestiones Indígenas de Naciones Unidas presentó la importancia que reviste la DNUDPI. Señaló que la aplicación de la declaración beneficia a los pueblos indígenas, pero también al planeta y al resto del mundo. En sus palabras, asegura que

si nos permiten vivir de acuerdo con nuestro modo sostenible de cuidar la tierra y de cuidar de nuestros familiares, de las plantas, animales y otros seres vivos, todos nos beneficiaremos. Si somos capaces de continuar hablando nuestros idiomas y de conservar nuestras culturas, contribuiremos a enriquecer el patrimonio cultural del mundo. Si nuestros diferentes sistemas económicos, culturales, espirituales, 
sociales y políticos pueden coexistir con otros sistemas dominantes, legaremos a nuestros hijos y nietos un mundo más diverso y estimulante. (Tauli-Corpuz 2008, 18)

De esta forma, en la fase del multiculturalismo se consolidan las organizaciones indígenas y se avanza en la consagración de los derechos de los pueblos indígenas al territorio, a la identidad cultural, la autonomía, la autodeterminación, la educación, a los recursos naturales, la salud, la participación y la consulta previa, entre otros. Estas normas se constituyen entonces en la base del desarrollo y la protección de los pueblos indígenas, derechos que además han sido garantizados en reiterada jurisprudencia por la Corte Constitucional colombiana ( $\mathrm{ccc}$ ), como veremos a continuación.

Debe observarse que la multiplicación de las organizaciones y la nacionalización del movimiento indígena ocurrieron en medio de tensiones y conflictos sociales. La movilización jurídica en materia de derechos de los pueblos indígenas debe relacionarse con la emergencia del movimiento más o menos global de los derechos de estos pueblos, el cual ganó influencia en el escenario internacional de los años noventa al interior de la Organización de las $\mathrm{Na}$ ciones Unidas. Este proceso implicó nuevas oportunidades políticas internacionales para las ONG indígenas, como el auge de las movilizaciones jurídicas internacionales en los años noventa y la primera década del 2000, a través de la redefinición de las bases del derecho internacional de los derechos humanos de los pueblos indígenas en los foros de la onu y la oEA (Santamaría 2010,178).

En el caso colombiano, el proceso constitucional explicita tanto los retos teóricos como prácticos concretos, generados por la tensión que existe entre los derechos individuales y la diferencia cultural. En el marco del multiculturalismo, los cambios jurisprudenciales que ha experimentado la Corte Constitucional colombiana demuestran lo difícil que es comprender y resolver el conflicto entre los valores liberales y la diferencia cultural. También evidencian que ha luchado por encontrar una solución que equilibre adecuadamente los valores en tensión (Bonilla Maldonado 2006, 192), en un mundo globalizado, donde los conflictos ambientales en territorios indígenas se constituyen en manifestación de dichas tensiones.

Una vez hechas las anteriores precisiones, se presentarán los resultados del trabajo de investigación, en el que se analizan los derechos de los pueblos indígenas y su aplicación en Colombia. 


\subsection{Reflexiones}

¿Qué podemos concluir de los antecedentes nacionales e internacionales que han dado lugar a los derechos consagrados a pueblos indígenas y a otros grupos étnicos? En primer lugar, estos pueblos y grupos consiguieron estos derechos colectivos gracias a sus luchas en defensa del territorio, la cultura y la autonomía. Varios hechos históricos ilustran su resistencia: la lucha de los esclavos (afrodescendientes) traídos o secuestrados durante la época de la colonia por lograr la libertad y su fuga para constituir sus palenques; o lo acontecido a principios del siglo xx en la Casa Arana, donde los indígenas eran obligados a trabajar como esclavos en la explotación del caucho, siendo sometidos además a látigos y torturas.

Otro ejemplo tiene que ver con el hecho de que a principios del siglo $\mathrm{xx}$, el indígena Manuel Quintín Lame movilizó la idea de defender los derechos indígenas mediante el conocimiento de la ley estatal y a partir de la recuperación y ampliación de la tierra de los resguardos; del fortalecimiento de los cabildos y de dar a conocer las leyes sobre los indígenas y exigir su justa aplicación.

De esta forma, dicha tradición y lucha alimentan e inspiran la movilización de los últimos años de los indígenas de casi todo el país, especialmente los del departamento de Cauca. Allí se busca que se garanticen sus derechos territoriales y su autonomía, mediante solicitudes y marchas, tomas de tierra e incluso su ocupación. La recuperación de los territorios como fuente cultural y de autonomía, así como de sentimiento de armonía y convivencia con la naturaleza, responde a un cúmulo de luchas y reclamos por parte de las comunidades étnicas del país que obedecen a su visión y cosmología del territorio.

En segundo lugar, el sentido de territorialidad de los indígenas, de tanta trascendencia, se ha desconocido y violentado. Para estos pueblos, en sus territorios era donde habitaban sus antepasados, donde ellos nacieron, crecieron y donde han manifestado sus culturas. Ese sentido les permite garantizar la existencia de una identidad cultural, sus formas organizativas y el gobierno propio. En todo esto, la autonomía ha desempeñado un importante papel.

Por eso, a lo largo de la historia, las comunidades y pueblos indígenas en general han protegido los territorios colectivos, porque de ellos depende su pervivencia y por ello se encuentran comprometidos en su conservación a través de un manejo autónomo y sostenible. 
En tercer lugar, es antigua la vulneración de esos derechos por parte de diversos actores, entre ellos, el Estado, al que le corresponde respetar y hacer respetar la importancia especial que para ellos y sus valores espirituales reviste su relación con las tierras o territorios que a través del tiempo han habitado. Desde hace muchos años se ha vulnerado ese derecho: desde la colonia, cuando se les consideraba salvajes o esclavos carentes de derechos, hasta hoy, cuando, no obstante ya encontrarse un reconocimiento y protección mediante instrumentos jurídicos como la Constitución Política de 1991, el Convenio 169 de la oIT y otras disposiciones especiales, siguen siendo vulnerados.

Con el análisis presentado se puede establecer que también sus luchas por la defensa territorial son fundamentales para su pervivencia como culturas. En la actualidad, esa tensión entre los programas de desarrollo del gobierno y los pueblos indígenas tiende a agravarse de manera especial, como consecuencia de los megaproyectos y de la vulneración de sus derechos.

En cuarto lugar, la situación actual representa también muchos desafíos para los pueblos indígenas, diferentes a los que antes debían enfrentar, como la necesidad de contar con una unidad en sus luchas y en el ejercicio del derecho a la resistencia, lo que los convoca a poseer líderes con conocimiento y amplia experiencia en el ámbito colombiano y en el mundo entero; con organizaciones consolidadas en lo local, lo regional, nacional e internacional y el surgimiento de alianzas y redes de apoyo.

Con las anteriores precisiones en mente, a continuación se estudiarán los diversos derechos de los pueblos indígenas, teniendo en cuenta para ello tanto la normatividad como la jurisprudencia y la doctrina que se presenta en la materia. 



\section{Capítulo 2 \\ Derechos de los pueblos indígenas consagrados en Colombia}

La protección de la diversidad étnica y cultural, la autodeterminación, la autonomía y la equidad de los pueblos indígenas tienen correspondencia con sus derechos territoriales, sociales, ambientales y culturales, y por ello se constituyen en un gran avance para ellos. Dicho de otra manera, los indígenas tienen derecho, en condiciones de igualdad, al goce y a la protección de todos los derechos humanos ${ }^{30} \mathrm{y}$ de las libertades fundamentales que se les han reconocido y que se encuentran contenidos en diversos instrumentos jurídicos nacionales e internacionales.

Para evaluar de manera continua la eficacia de esos derechos y libertades y la situación de las colectividades, se requiere establecer mecanismos de monitoreo adecuados. En este contexto, toda acción debe emprenderse con la participación de los pueblos indígenas y con el debido respeto a su identidad social y cultural, costumbres, tradiciones, aspiraciones y formas de vida (oIT 2009, 29).

\subsection{Alcance y contenido de los derechos}

$\mathrm{El}$ reconocimiento de los derechos de los pueblos indígenas en la Constitución promulgada en 1991 marcó un hito en la historia del constitucionalismo en Colombia: convirtió a los indígenas y a otros grupos étnicos en sujetos jurídicos de orden constitucional, cuando se les reconocieron más de dos docenas de derechos. Además, la Corte Constitucional ha producido jurisprudencia innovadora

\footnotetext{
${ }^{30}$ Expertos como Mesa Cuadros (2007) plantean que todos los derechos son humanos; indica que no hay unos en especial, ni otros en particular; advierte que los derechos tampoco se reducen a aquellos que define el Estado al aceptar las presiones de determinados actores sociales, políticos y económicos, que consideran que hay derechos principales o fundamentales. Hay derechos que para unos grupos humanos son mucho más importantes que los que el Estado prefija por imposición de los intereses que se mueven en el poder.
} 
sobre el significado de las sociedades indígenas para el ordenamiento jurídico. Las posiciona como estructuras portadoras de derechos específicos (Castrillón Orrego 2008,158), como se verá a continuación.

\subsubsection{Valoración de los instrumentos internacionales}

Aunque existen varios tratados internacionales que consagran derechos en cabeza de los pueblos indígenas (véase tabla 5), el Convenio 169 de la oiT es el único que tiene que ver directamente con su protección. Por tanto, "después de la Constitución Nacional, es el instrumento legal más importante con que cuentan los pueblos indígenas para defender sus derechos", tal como afirma el ex constituyente indígena y ex senador de la república, Lorenzo Muelas Hurtado $(1997,9)$. Allí se consagran importantes normas, se establece como obligación de los Estados reconocer el derecho de propiedad y de posesión sobre las tierras que tradicionalmente han ocupado y la de respetar las modalidades de transmisión de los derechos que han sido establecidas por ellos. El ex constituyente agrega que, de acuerdo con este convenio, los gobiernos deberán garantizar la importancia especial que para las culturas y valores espirituales de los pueblos reviste su relación con las tierras o territorios que ocupan.

Tabla 5. Principales instrumentos internacionales de protección de los pueblos indígenas y ley que los ratifica en Colombia

\begin{tabular}{|c|c|c|}
\hline $\begin{array}{l}\text { Instrumento } \\
\text { (número, año, entidad } \\
\text { responsable) }\end{array}$ & $\begin{array}{l}\text { Ley de ratificación en } \\
\text { Colombia }\end{array}$ & Descripción \\
\hline $\begin{array}{l}\text { Convenio } 107 \text { de } 1957 \\
\text { - } \text { oIT }^{31}\end{array}$ & Ley 31 de 1967 & $\begin{array}{l}\text { Protección a las poblaciones indígenas y tri- } \\
\text { bales en los países independientes. }\end{array}$ \\
\hline $\begin{array}{l}\text { Pacto Internacional de } \\
\text { Derechos Económicos, } \\
\text { Sociales y Culturales - } \\
1966 \text { - ONU }{ }^{3}\end{array}$ & Ley 74 de 1968 & $\begin{array}{l}\text { Los Estados se comprometen a asegurar a los } \\
\text { hombres y las mujeres igual título para gozar } \\
\text { de todos los derechos económicos, sociales y } \\
\text { culturales. }\end{array}$ \\
\hline $\begin{array}{l}\text { Pacto Internacional de } \\
\text { Derechos Civiles y Políti- } \\
\text { cos }-1966-\text { oNU }\end{array}$ & Ley 74 de 1968 & $\begin{array}{l}\text { Los Estados se comprometen a garantizar a } \\
\text { hombres y mujeres la igualdad en el goce de } \\
\text { todos los derechos civiles y políticos. }\end{array}$ \\
\hline
\end{tabular}

Continúa

${ }^{31}$ Este convenio se utiliza todavía en 17 países como instrumento para garantizar ciertos derechos mínimos. Empero, quedó cerrado a nuevas ratificaciones desde la entrada en vigor del Convenio 169 (oIT 2013,4). 


\begin{tabular}{|c|c|c|}
\hline $\begin{array}{l}\text { Instrumento } \\
\text { (número, año, entidad } \\
\text { responsable) }\end{array}$ & $\begin{array}{l}\text { Ley de ratificación en } \\
\text { Colombia }\end{array}$ & Descripción \\
\hline $\begin{array}{l}\text { Tratado de Cooperación } \\
\text { Amazónica } 1978 \text { - отсA }\end{array}$ & Ley 17 de 1981 & $\begin{array}{l}\text { Realizar esfuerzos para promover el desa- } \\
\text { rrollo armónico de sus respectivos territorios } \\
\text { amazónicos tendientes a lograr resultados } \\
\text { equitativos y mutuamente provechosos, así } \\
\text { como para la preservación del ambiente y } \\
\text { la conservación y utilización racional de los } \\
\text { recursos naturales de esos territorios. }\end{array}$ \\
\hline $\begin{array}{l}\text { Convención sobre los } \\
\text { derechos del niño - } 1989 \\
\text { - ONU }\end{array}$ & Ley 12 de 1991 & $\begin{array}{l}\text { Por el cual los Estados partes se comprome- } \\
\text { ten a reconocer los derechos de los niños y } \\
\text { a adoptar medidas para dar efectividad a los } \\
\text { mismos. }\end{array}$ \\
\hline $\begin{array}{l}\text { Convenio } 169 \text { de } 1989 \\
\text { - OIT }\end{array}$ & Ley 21 de 1991 & $\begin{array}{l}\text { Versión revisada del Convenio } 107 \text { de } 1957 . \\
\text { Busca asegurar los derechos de los pueblos } \\
\text { indígenas y tribales a su territorio y la pro- } \\
\text { tección de sus valores culturales, sociales y } \\
\text { económicos. }\end{array}$ \\
\hline $\begin{array}{l}\text { Convenio sobre Diversi- } \\
\text { dad Biológica } 1993 \text { - onU }\end{array}$ & Ley 165 de 1994 & $\begin{array}{l}\text { Conservación de la diversidad biológica, la } \\
\text { utilización sostenible de sus componentes } \\
\text { y la participación justa y equitativa en los } \\
\text { beneficios que se deriven de la utilización de } \\
\text { los recursos. }\end{array}$ \\
\hline $\begin{array}{l}\text { Decisión } 391 \text { de } 1996 \text { - } \\
\text { Comisión del Acuerdo de } \\
\text { Cartagena - Comunidad } \\
\text { Andina }\end{array}$ & $\begin{array}{l}\text { No requiere } \\
\text { ratificación }\end{array}$ & $\begin{array}{l}\text { Reglamenta los artículos } 8,10 \text { y } 15 \text { del } \\
\text { Convenio de Biodiversidad, que tratan de } \\
\text { la protección al conocimiento asociado a los } \\
\text { recursos genéticos, su acceso, la distribución } \\
\text { de los beneficios y la utilización. Establece } \\
\text { el régimen común de acceso a los recursos } \\
\text { genéticos. }\end{array}$ \\
\hline $\begin{array}{l}\text { Declaración de las Na- } \\
\text { ciones Unidas sobre los } \\
\text { derechos de los pueblos } \\
\text { indígenas - } 2007 \text { - ONU }\end{array}$ & & $\begin{array}{l}\text { La Asamblea General de la onu adopta la } \\
\text { DNUDPI, que establece un marco universal de } \\
\text { estándares mínimos para la dignidad, bien- } \\
\text { estar y derechos de los pueblos indígenas del } \\
\text { mundo. }\end{array}$ \\
\hline $\begin{array}{l}\text { Convención Internacio- } \\
\text { nal sobre la Eliminación } \\
\text { de todas las formas de } \\
\text { Discriminación Racial- } \\
\text { 1965 - ONU }\end{array}$ & Ley 1482 de 2011 & $\begin{array}{l}\text { Mediante la cual los Estados partes con- } \\
\text { denan especialmente la segregación racial } \\
\text { y el apartheid y se comprometen a prevenir, } \\
\text { prohibir y eliminar todas las prácticas de esta } \\
\text { naturaleza. }\end{array}$ \\
\hline
\end{tabular}

Fuente: Elaboración de la autora.

Con respecto a la existencia de diversos instrumentos internacionales, la profesora Yrigoyen Fajardo $(2010,20)$ asegura que cuatro de ellos han marcado 
el desarrollo de las políticas y los derechos indígenas en las últimas décadas. Estos instrumentos internacionales son:

- La Convención sobre el Instituto Indigenista Interamericano (III) de 1940.

- E1 Convenio 107 de la oit sobre Poblaciones Indígenas y Tribales en Países Independientes de 1957.

- El Convenio 169 de la orT sobre Pueblos Indígenas y Tribales en Países Independientes de 1989.

- La Declaración de Naciones Unidas sobre los derechos de los pueblos indígenas (DNUDPI) de 2007.

Y agrega que el corpus de derechos indígenas responde a las luchas y demandas de estas colectividades, las cuales se han desarrollado buscando, por un lado, reparar en parte las injusticias históricas y, por otro, brindar condiciones para un nuevo entendimiento entre los Estados, los pueblos indígenas y la sociedad en su conjunto (Yrigoyen Fajardo 2010,18). A partir del Convenio 169 y la DNUDPI, estos derechos tienen como horizonte la construcción de sociedades más democráticas y un mundo global más justo, sobre la base del reconocimiento de la igual dignidad y derechos de los pueblos indígenas. Plantea esta autora que no basta con la adopción de instrumentos internacionales para que el reconocimiento de los derechos tenga eficiencia y que su eficacia se puede medir por el grado del:

- Ejercicio directo de derechos por parte de sus beneficiarios o titulares.

- Respeto de los derechos indígenas por parte de las autoridades y terceros.

- Aplicación o implementación de derechos mediante políticas públicas o acciones positivas del Estado.

- Protección o garantía de derechos por parte de los órganos jurisdiccionales correspondientes, cuando estos son incumplidos o vulnerados (Yrigoyen Fajardo 2010, 19).

En todo caso, de acuerdo con la DNUDPI, los tratados, acuerdos y demás arreglos constructivos, y las relaciones que estos representan, sirven de base para el fortalecimiento de la asociación entre los pueblos indígenas y el Estado. 


\subsubsection{Vínculos entre instrumentos internacionales y nacionales}

En este escenario, se pueden destacar algunos de los derechos consagrados a favor de estos pueblos. ${ }^{32}$ Para comenzar, del Convenio 169 surgen dos grandes conjuntos de compromisos para los Estados: el primero, referido a las medidas que estos deben impulsar para obtener los fines propios del instrumento en los aspectos que son su objeto; el segundo, a la manera como deben adoptarse y ponerse en ejecución esas medidas y que tienen como elementos centrales la participación y el respeto por la diversidad y la autonomía.

El convenio se orienta a promover las condiciones que permitan el desarrollo de los pueblos indígenas de un modo que respete la diversidad étnica y cultural, asegure los espacios de autonomía requeridos para ello y se desenvuelva en un marco de igualdad, y que específicamente se refiere a su relación con las tierras o territorios; a las condiciones de trabajo; a aspectos relacionados con la formación profesional, la artesanía y las industrias rurales; a salud y seguridad social; a educación y medios de comunicación y a contactos y cooperación a través de las fronteras (ccc, C-030/0833).

Pues bien, con la ayuda de fuerzas políticas progresistas, los pueblos indígenas obtuvieron en la Asamblea Nacional Constituyente el reconocimiento constitucional del carácter multicultural y poliétnico que ha conformado a Colombia desde su nacimiento. Más aún, la Constitución Política de 1991 promulgó una serie de derechos para la promoción y protección de la diversidad cultural que, según el profesor Bonilla Maldonado (2006, 29-30), pueden dividirse en tres categorías: primera, la de aquellos que promueven el autogobierno; segunda, la de los que impulsan la participación política; tercera, la de los derechos que protegen y promueven las expresiones, defensa y reproducción del patrimonio cultural.

\footnotetext{
32 Para ello, se tendrán en cuenta dos principios en los que se fundamenta el Convenio 169: (1) el de la igualdad de derechos entre los pueblos indígenas y el resto de la población de los Estados en que viven y (2) el del respeto por las culturas e instituciones de estas colectividades. Las disposiciones del convenio apuntan a superar la discriminación, a garantizar que estas comunidades se beneficien en forma igualitaria en la sociedad nacional y a garantizar que puedan desarrollar su identidad social y cultural, costumbres, tradiciones e instituciones, de acuerdo con sus propias aspiraciones (огт 2009, 36).

${ }^{33}$ Mediante la cual la Corte Constitucional estudia una demanda de inconstitucionalidad contra la Ley 1021 de 2006 o Ley General Forestal, que terminó siendo declarada inexequible.
} 
Por otro lado, desde sus dos primeros artículos, la DNUDPI consagra que los indígenas tienen derecho, como pueblos y/o como personas, al disfrute pleno de todos los derechos humanos y las libertades fundamentales reconocidos por la Carta de las Naciones Unidas, la Declaración Universal de Derechos Humanos y la normativa internacional de los derechos humanos. Los pueblos, las comunidades y las personas indígenas son libres e iguales a todos los demás pueblos y personas y tienen derecho a no ser objeto de ninguna discriminación en el ejercicio de sus derechos que esté fundada, en particular, en su origen o identidad indígena.

De manera concomitante, la jurisprudencia de la Corte Constitucional colombiana ( $\mathrm{ccc}$ ) ha garantizado mediante varios pronunciamientos los derechos de los pueblos indígenas y ha brindado claridad sobre su protección. ElTribunal Constitucional (ccc, T-973/0934) subraya que estas comunidades y pueblos indígenas son titulares de los siguientes derechos:

(a) A la subsistencia, derivado de la protección constitucional a la vida (art. $11 \mathrm{cP})$.

(b) A la integridad étnica, cultural y social, del que se desprenden tanto la protección a la diversidad y al carácter pluralista de la nación (art. 1,7 y 8 cP), como el derecho a la supervivencia cultural, el derecho a la preservación de su hábitat natural, el derecho de la comunidad a determinarse por su cosmovisión religiosa y a hacerla valer ante terceros y la prohibición de toda forma de desaparición forzada (artículo $12 \mathrm{cP}$ ).

(c) A su autodeterminación y autogobierno (art. 9 y $330 \mathrm{cP}$ ).

(d) El derecho a la oficialidad de lenguas y dialectos de las comunidades nativas y a que la enseñanza que se les imparta sea bilingüe (art. $10 \mathrm{CP}$ ).

(e) Al respeto a la identidad cultural en materia educativa (art. $68 \mathrm{cP}$ ).

(f) $\mathrm{Al}$ reconocimiento de la igualdad y dignidad de todas las formas de cultura (art. $70 \mathrm{cP})$.

\footnotetext{
${ }^{34}$ Correspondiente a una acción de tutela en contra el Ministerio del Interior y de Justicia, por considerar que había estimulado la división interna de la comunidad indígena Kamëntsá Biyá del municipio de Sibundoy (Putumayo), al inscribir una elección de gobernador vulnerando los derechos fundamentales al debido proceso, a la igualdad, a la participación en la conformación, ejercicio y control del poder político y el derecho a la autonomía por interferir indebidamente en las decisiones internas de la comunidad, con relación a la elección de su autoridad tradicional.
} 
(g) A la protección del patrimonio arqueológico de la nación (art. 72 cP).

(h) A una circunscripción especial para la elección de senadores y representantes (art. 171 y $176 \mathrm{cP}$ ).

(i) A administrar justicia en su propio territorio y a regirse por sus propias normas y procedimientos (art. $246 \mathrm{cP}$ ).

(j) A la propiedad colectiva y su naturaleza inalienable, imprescriptible e inembargable (art. 58, 63 y $329 \mathrm{cP}$ ).

(k) A gobernarse por consejos indígenas y autoridades por ellos elegidas, según sus usos y costumbres y a determinar sus propias instituciones jurídicas (art. $330 \mathrm{cP}$ ).

(l) A acudir como comunidad a la justicia.

(m) A la consulta previa.

Por otro lado, la DNUDPI señala que el ejercicio de los derechos establecidos en la declaración está sujeto exclusivamente a las limitaciones determinadas por la ley y con arreglo a las obligaciones internacionales en materia de derechos humanos. Esas limitaciones no deben ser discriminatorias y son sólo las estrictamente necesarias para garantizar el reconocimiento y respeto debidos a los derechos y libertades de los demás y para satisfacer las justas y más apremiantes necesidades de una sociedad democrática (artículo 46.2).

$\mathrm{Al}$ respecto, el esfuerzo de la Corte Constitucional por 'tomarse en serio' el carácter multicultural de la Constitución la hace pionera en el tema, aunque la jurisprudencia emanada de ella se muestra en algunos casos contradictoria o expresa dificultades. A pesar de esto, avanza formulando importantes criterios de decisión, que vale la pena conocer y discutir, como lo plantea Botero Marino $(2003,46)$, pues además ofrece la línea de argumentación que permite la defensa y promoción de los derechos de los pueblos indígenas en un modelo constitucional fundado en el respeto de los derechos humanos.

En este contexto, la presente investigación avanza en ilustrar y analizar otra contradicción: hay derechos reclamados de manera recurrente en los casos de los conflictos analizados. Las comunidades y pueblos indígenas los mencionaron en los talleres promovidos por este estudio, de modo que se evidencian las tensiones y dificultades que surgen al incorporar, en una Constitución de estirpe liberal, el modelo multicultural (Botero Marino 2003, 46). Se trata, en especial, de los siguientes derechos: a la identidad cultural, a la autodeterminación y a la 
autonomía, al territorio, a los recursos naturales, el derecho propio o consuetudinario y el derecho a la participación.

\subsubsection{Derecho a la identidad cultural}

Rodolfo Stavenhagen (2000, 24-30), ex relator especial sobre la situación de los derechos humanos y las libertades fundamentales de los indígenas, señala que los grupos étnicos ${ }^{35}$ se forman y adquieren su identidad (lo que en la literatura se conoce ocasionalmente con el nombre de etnogénesis) como resultado de diferentes procesos históricos. La identidad y la continuidad étnica se mantienen como efecto de la transmisión en el grupo, de las normas y costumbres básicas (mediante la socialización, la educación y la internalización de valores), que constituyen el núcleo de la cultura étnica. Con el tiempo, pueden variar los patrones culturales, pero eso sólo se da en forma lenta y a lo largo de varias generaciones.

La Declaración Universal sobre la Diversidad Cultural, emanada de la Organización de las Naciones Unidas para la Educación, la Ciencia y la Cultura —en adelante, UNESCO-, señala que, con el tiempo y en múltiples espacios, la cultura adquiere formas diversas. Esas formas se manifiestan en la originalidad y la pluralidad de las identidades que caracterizan los grupos y las sociedades humanas. Fuente de intercambios, de innovación y de creatividad, la diversidad cultural es, para el género humano, tan necesaria como la biodiversidad para los organismos vivos. En este sentido, resalta la declaración, la identidad cultural constituye el patrimonio común de la humanidad

\footnotetext{
${ }^{35}$ Para Rodolfo Stavenhagen $(2000,28)$, ni las ciencias sociales, incluida la ciencia jurídica, ni el uso popular han alcanzado consenso sobre la terminología étnica. Asegura que esta es diferente en América Latina, donde se considera que las comunidades indígenas (amerindios) se encuentran en el escalón más bajo de la escala de desarrollo socioeconómico dentro de los estados-nación unitarios. Aunque en ocasiones se emplean categorías raciales, el concepto de indios o grupos indígenas, a diferencia del de poblaciones "nacionales", denota básicamente una categoría cultural y socioeconómica. Se sostiene que en el proceso de "desarrollo" e "integración nacional” las culturas indígenas se asimilarán o modernizarán y, por lo tanto, tenderán a desaparecer o fundirse en el todo nacional. Los indígenas mismos prefieren ser reconocidos como "pueblos" más que "poblaciones", "comunidades" o "minorías", ya que como pueblos consideran que pueden reclamar para sí ciertos derechos de acuerdo con los principios internacionales de derechos humanos.
} 
y debe reconocerse y consolidarse en beneficio de las generaciones presentes y futuras. ${ }^{36}$

En el marco jurídico nacional, la Ley 397 de 1997 define la cultura como el conjunto de rasgos distintivos, espirituales, materiales, intelectuales y emocionales que caracterizan a los grupos humanos y que comprenden, más allá de las artes y las letras, modos de vida, derechos humanos, sistemas de valores, tradiciones y creencias (Ley General de Cultura). En palabras de los propios indígenas, entre las creaciones y elementos propios del grupo o comunidad que constituyen su cultura, hay que mencionar especialmente la lengua, como medio de comunicación; la educación e integración de sus miembros, las instituciones propias que hacen posible la vida como colectividad, las tradiciones, usos, costumbres y espiritualidad que expresan su concepción de la divinidad y de la misma vida; la cosmovisión colectiva, que fluye como producto de estos rasgos compartidos y que supone la manera como se entiende el mundo y el conocimiento tradicional — tangible e intangible - (onIC 2007a, 35-36).

Contando con los anteriores elementos, es deber del Estado reconocer y proteger los valores y prácticas sociales, culturales, religiosas y espirituales propias de los pueblos indígenas y tomar debidamente en consideración la índole de los problemas que se les plantean tanto colectiva como individualmente. Así mismo, el Estado debe respetar el derecho a la propia definición y conciencia de identidad y debe adoptar medidas especiales para salvaguardar las culturas (Convenio 169 de la OIT).

De esta manera, al consagrar el respeto a la multiplicidad de formas de vida por medio del reconocimiento del pluralismo y de las garantías a la diversidad étnica y cultural, la Constitución Política ${ }^{37}$ modificó el modelo tradicional de relación del Estado colombiano con los pueblos indígenas: subvirtió un patrón basado en la asimilación e integración de estas comunidades a las cosmovisiones mayoritarias e introdujo un proceso participativo

\footnotetext{
${ }^{36}$ Para profundizar en el tema, véase http://portal.unesco.org/es/ev.php-URL_ID=13179\&URL_ DO=DO_TOPIC\&URL_SECTION $=201 . \mathrm{html}$

${ }^{37}$ En este sentido, el artículo 7 de la Constitución Política de Colombia señala que se debe proteger la diversidad étnica y cultural de nuestra nación, representada en los diferentes pueblos étnicos, en sus lenguas y cosmovisiones, porque, según la Ley 397 de 1997, la cultura, en sus diversas manifestaciones, es fundamento de la nacionalidad y actividad propia de la sociedad colombiana en su conjunto, como proceso generado individual y colectivamente por los colombianos. Dichas manifestaciones constituyen parte integral de la identidad y la cultura.
} 
y de reconocimiento del otro, que acepta y propugna por el derecho de las minorías tradicionales a sobrevivir, crecer y desarrollarse con sujeción a sus propios valores étnicos y culturales (ccc, T-380/93, C-104/95 y C-208/07).

En este sentido, le corresponde al Estado garantizar a los grupos étnicos y lingüísticos los derechos a conservar, enriquecer y difundir su identidad y patrimonio cultural, a generar el conocimiento según sus propias tradiciones y a beneficiarse de una educación que asegure estos derechos. De igual manera, debe proteger las lenguas de los pueblos indígenas en sus territorios, impulsar el fortalecimiento de las lenguas amerindias y criollas habladas en el territorio nacional y comprometerse con el respeto y reconocimiento de estas en el resto de la sociedad ${ }^{38}$.

Lo anterior implica que los pueblos indígenas tienen derecho a que se reconozcan sus valores, sus costumbres y tradiciones y que es deber del Estado colombiano adoptar medidas especiales para salvaguardar las personas, las instituciones, los bienes, el trabajo, las culturas y el ambiente de estos pueblos, teniendo en cuenta sus deseos, expresados en forma libre. Además, debe respetar las instituciones propias y permitir su participación y cooperación en las medidas que se adopten para resolver sus dificultades.

Con respecto a las obligaciones de los Estados partes de la Convención de las Naciones Unidas contra la Discriminación Racial, el Comité para la Eliminación de la Discriminación Racial (CEDR) exhortó a los Estados a que: ${ }^{39}$

a) Reconozcan y respeten la cultura, la historia, el idioma y el modo de vida de las poblaciones indígenas como un factor de enriquecimiento de la identidad cultural del Estado y garanticen su preservación;

b) Garanticen que los miembros de las poblaciones indígenas sean libres e iguales en dignidad y libres de toda discriminación, en particular la que se base en el origen o la identidad indígena;

${ }^{38}$ Mediante la Ley 1381/10 se dictan normas sobre reconocimiento, fomento, protección, uso, preservación y fortalecimiento de las lenguas de los grupos étnicos de Colombia y sobre sus derechos lingüísticos y los de sus hablantes. Dicha norma tiene como objeto garantizar el reconocimiento, la protección y el desarrollo de los derechos lingüísticos, individuales y colectivos de los grupos étnicos con tradición lingüística propia, así como la promoción del uso y desarrollo de sus lenguas.

${ }^{39}$ Recomendación General del CEDR sobre poblaciones indígenas, supra, nota 11, párr. 4. Referenciado (Anaya 2005, 180). 
c) Proporcionen a las poblaciones indígenas las condiciones que les permitan un desarrollo económico y social sostenible, compatible con sus características culturales;

d) Garanticen que los miembros de las poblaciones indígenas gocen de derechos iguales con respecto a su participación efectiva en la vida pública y que no se adopte decisión alguna directamente relacionada con sus derechos e intereses sin su consentimiento informado;

e) Garanticen que los miembros de las poblaciones indígenas puedan ejercer su derecho a practicar y reavivar sus tradiciones y costumbres y preservar y practicar su idioma.

Por otro lado, la DNUDPI reconoce el derecho que tienen los pueblos a ser diferentes, a considerarse a sí mismos distintos y a ser respetados como tales. Además, que el ejercicio de sus derechos debe estar libre de toda forma de discriminación y que el respeto de los conocimientos, las culturas y las prácticas tradicionales de los pueblos indígenas contribuye al desarrollo sostenible y equitativo y a la ordenación del ambiente.

Así las cosas, según establece el artículo 2 de la declaración, los pueblos y las personas, indígenas son libres e iguales a todos los demás pueblos y personas y tienen derecho a no ser objeto de ninguna discriminación en el ejercicio de sus derechos que esté fundada, en particular, en su origen o identidad indígena.

\subsection{Jurisprudencia sobre el derecho a la identidad cultural}

Hemos dicho ya que en los últimos tiempos proliferan en el mundo las luchas por el reconocimiento y que estas impulsan muchos de los conflictos sociales. Se caracterizan por ser heterogéneas, pero implican un cambio de vientos políticos, como lo dice Fraser $(2008,96)$. En nuestro país, también se da este debate. Particularmente, en el ámbito jurisprudencial, a partir de los derechos de los pueblos indígenas. Se considera que la identidad cultural es un derecho fundamental. 
En la Sentencia de Unificación su-510/98, ${ }^{40}$ la Corte Constitucional asegura que el principio de diversidad e integridad personal no es una declaración retórica: constituye una proyección, en el plano jurídico, del carácter democrático, participativo y pluralista de la república colombiana y obedece a la aceptación de la alteridad. Esta a la vez se liga a la aceptación de la multiplicidad de formas de vida y sistemas de comprensión del mundo, diferentes a los de la cultura occidental.

En esas condiciones, la Constitución Política permite al individuo que defina su identidad sobre la base de sus diferencias específicas y de valores étnicos y culturales concretos y no conforme a un concepto abstracto y general de ciudadanía, como el estipulado por los Estados liberales unitarios y monoculturales. Lo anterior traduce, según este alto tribunal, un afán válido de adaptar el derecho a las realidades sociales, a fin de satisfacer las necesidades de reconocimiento de aquellos grupos que se caracterizan por ser diferentes en cuestiones de raza o cultura. En suma, el reconocimiento de la diversidad étnica y cultural obedece al imperativo de construir una democracia cada vez más inclusiva y participativa y de ser consecuentes con la concepción según la cual la justicia se constituye en un ideal incompleto si no se atienden las reivindicaciones de reconocimiento de los individuos y comunidades (ccc, T-778/05 ${ }^{41}$.

La Corte Constitucional (T-778/05) ha señalado también que el Estado colombiano no se debe limitar a reconocer y proteger las diversas culturas que son fundamento de la nacionalidad colombiana: por mandato constitucional, debe difundir y promover la difusión de los valores culturales que se manifiestan en cosmovisiones diversas, características de las colectividades humanas, pero todas igualmente dignas de proyección en el ámbito de la nación en la que conviven. Para este alto tribunal, el derecho a la identidad cultural, derivado

\footnotetext{
${ }^{40}$ Acción de tutela interpuesta por la Iglesia Pentecostal Unida de Colombia —IPUc—y 31 indígenas arhuacos, contra varias autoridades de la comunidad indígena arhuaca, por considerar que vulneraban sus derechos fundamentales a la vida, a la integridad personal, al libre desarrollo de la personalidad, a la libertad de conciencia, a la libertad religiosa y de culto, a la libertad de expresión, a la honra y a la libertad personal.

${ }^{41}$ Acción de tutela instaurada por Ati Seygundiba Quigua Izquierdo contra el Tribunal Administrativo de Cundinamarca por haber ordenado la nulidad de su elección como concejal por no cumplir con el requisito de edad. La Corte Constitucional termina por amparar los derechos fundamentales de la tutelante y ordena la suspensión de los efectos del fallo.
} 
del principio a la diversidad étnica y cultural establecido en el artículo 7 de la Constitución, se ha concebido como un derecho fundamental. Una de las formas de materializar este derecho consiste en que las comunidades que no ostentan los valores culturales y sociales de la sociedad mayoritaria pueden ejercer sus derechos fundamentales de acuerdo con su propia manera de ver el mundo. Ello implica que también los individuos que pertenecen a una comunidad o pueblo indígena puedan expresarse y autodeterminarse de acuerdo con su cosmovisión cultural, dentro y fuera de sus territorios.

Lo anterior, asegura la corte, comprende dos tipos de protección a la identidad cultural: una directa, que ampara a la comunidad como sujeto del derecho, y otra indirecta, que ampara al individuo para proteger la identidad de la comunidad.

Adicionalmente, la jurisprudencia constitucional consolida el derecho a la identidad cultural de las comunidades y pueblos indígenas, bajo el entendido de que su titularidad se encuentra en cabeza de estos como sujetos colectivos de derechos fundamentales. El derecho a la identidad cultural se proyecta más allá del lugar donde está ubicada la respectiva colectividad. Esto obedece a que el principio de diversidad étnica y cultural es fundamento de la convivencia pacífica y armónica dentro del respeto al pluralismo en cualquier lugar del territorio nacional, pues esto es presupuesto definitorio del Estado social y democrático de derecho. Es este un principio orientado a la inclusión dentro del reconocimiento de la diferencia, no a la exclusión so pretexto de respetar las diferencias. Concluir que la identidad cultural sólo se puede expresar en un determinado y único lugar del territorio equivaldría a establecer políticas de segregación y de separación. Las diversas identidades culturales pueden proyectarse en cualquier lugar del territorio nacional, puesto que todas son igualmente dignas y fundamento de la nacionalidad (ccc, T-778/05).

Por último, la Corte Constitucional ha señalado que este derecho tiene diversas manifestaciones, acordes con la fundamentalidad del principio de diversidad y el carácter multiétnico y multicultural de la nación colombiana (ccc, T-778/05). Lo anterior quiere decir que ha reconocido que la diversidad étnica y cultural es un principio constitucional del que se deriva el derecho fundamental a la identidad étnica, tanto de las comunidades y pueblos indígenas como de sus integrantes. Ese derecho puede ser definido como la facultad de todo grupo indígena y de sus miembros a formar parte de un determinado 
patrimonio cultural tangible o intangible y de no ser forzado a pertenecer a uno diferente o a ser asimilado por uno distinto (ccc, T-973/09).

\subsection{La cultura cambia}

Ahora bien, la Corte Constitucional (T-973/09) señala que la identidad cultural de una comunidad o pueblo indígena no puede concebirse a priori como una realidad estática, es decir, que implica una identificación cultural inamovible. La restricción a los avances y a los mecanismos de adaptación interna de un grupo étnico, con fundamento en el imaginario de una identidad étnica inmutable, puede llevar al estancamiento del diálogo interno, lo que pone en peligro su supervivencia física y cultural.

De ese modo, puesto que la identidad se reconstruye y revaloriza en forma dinámica, tanto por las continuas discusiones y avances internos, como por la influencia de otros grupos étnicos y otras culturas, es un derecho permitir también la adopción de elementos culturales nuevos, siempre que los cambios en las expresiones tradicionales sean el resultado de decisiones voluntarias, libres e informadas por parte del propio pueblo indígena.

Sobre el particular, asegura Stavenhagen $(2000,44)$ que la cultura define la forma de vida que distingue a un grupo étnico de otro. No es posible identificar a un grupo étnico sin su propia cultura. En la medida en que la cultura constituye un factor dinámico sujeto a transformaciones como resultado de distintas causas posibles, los cambios culturales también condicionan la identidad y viabilidad de los grupos étnicos.

En este contexto, es necesario señalar que algunos pueblos indígenas vienen, dada la asimilación cultural impuesta durante muchos años, en un proceso de re-etnización o re-indigenización, como lo plantean Lopera Mesa y Hoyos Ceballos (2008, 149-150). Estos autores sostienen que si el paradigma de la nación unitaria determinaba la negación de lo diverso, una de las principales estrategias adoptadas por los indígenas como respuesta a dicha exclusión fue la asimilación del patrón cultural hegemónico que definía la identidad nacional. Esta asimilación en buena medida les fue impuesta, pero en muchos casos también fue interiorizada por los propios indígenas en su intento por ser reconocidos como parte de la imaginada comunidad nacional. La narrativa de la nación unitaria se reemplazaría por la de una nación pluriétnica y pluricultural y la situación de esos 'otros' que son los indígenas experimentará una importante transformación, al menos en lo que respecta al plano de las 
representaciones y los discursos, con el reconocimiento constitucional de la diversidad étnica y cultural de la nación colombiana.

\subsection{Limites al derecho a la identidad cultural}

Los límites que la jurisprudencia ha establecido al derecho a la identidad cultural, según la Corte Constitucional, han comprendido el respeto al derecho a la vida, la prohibición a la tortura, la responsabilidad individual por los actos y la proporcionalidad de la pena a la gravedad de la falta. Para este alto tribunal, tal y como ocurre con la generalidad de los derechos fundamentales, los que se derivan de la diversidad étnica y cultural, no tienen un alcance absoluto. Las limitaciones a las que se encuentra sometida la autonomía de las comunidades y pueblos indígenas, en efecto, surgen en primer lugar del propio texto constitucional, que establece unas condiciones para su ejercicio, al resaltar prima facie (i) que nuestro país es un Estado unitario, con autonomía de sus entidades territoriales y (ii) que la autonomía política y jurídica de las comunidades puede ejercerse conforme a sus usos y costumbres, siempre y cuando estos no sean contrarios a la Constitución y a la ley (ccc, T- 778/05, T-973/09 y su-510/98).

La Corte Constitucional estableció unas reglas que facilitan la interpretación sobre los alcances y los límites de esa diversidad y su ponderación con otros derechos. Así, aunque ha considerado "aventurado establecer reglas generales", por cuanto la resolución de cada conflicto debe hacerse a la luz de las particularidades de las culturas étnicas involucradas, ha establecido en todo caso algunas reglas generales de interpretación.

Las mencionadas reglas versan para el alto tribunal (ccc, T-973/09) sobre el núcleo esencial de los derechos fundamentales constitucionales que constituye el mínimo obligatorio de convivencia para todos los particulares. La sujeción a la Constitución y a la ley es un deber de todos los nacionales (CP, arts. 4, 6 y 95) y el respeto a los derechos fundamentales es, en ese sentido, un límite material al principio de diversidad étnica y cultural y a los códigos de valores propios de las diversas comunidades y pueblos indígenas que habitan el territorio nacional.

Sobre la maximización de la autonomía, prevé en principio una tensión entre las normas y procedimientos propios de los indígenas y los límites trazados por la Constitución y la ley, encaminados a la consecución de los fines del Estado dentro de un marco instituido bajo el reconocimiento de la unidad 
nacional. No obstante, teniendo en cuenta que sólo con un alto grado de autonomía es posible la supervivencia cultural de una comunidad o pueblo indígena, la propuesta interpretativa que ha ofrecido la Corte Constitucional es la maximización de la autonomía de las comunidades y la minimización de las restricciones, salvo las que sean indispensables para salvaguardar intereses de superior jerarquía, como los derechos y principios enunciados. El pleno despliegue de la protección de la diversidad, además, sólo podrá producirse frente a aquellos conflictos que puedan ser catalogados como internos en las respectivas comunidades, al paso que cuando se trate de conflictos interculturales el parámetro de valoración será distinto, dependiendo de las circunstancias de cada caso, dado el reconocimiento en igualdad de condiciones de la diversidad propia de cada uno de los grupos involucrados.

Además, la Corte Constitucional indica que a mayor conservación de usos y costumbres, mayor autonomía. Esta es una regla que asegura que a mayor claridad de las reglas internas de una comunidad o pueblo indígena en todo sentido —incluso en materia política y electoral—, menor será la intervención del Estado en sus designios internos. De hecho, en atención a la seguridad jurídica y social que ofrecen los usos y costumbres dentro de una colectividad indígena, ha dicho esta corte que se debe distinguir entre los grupos étnicos que conservan tales tradiciones de aquellos que no lo hacen. En el primer caso, las reglas diseñadas por la tradición de las comunidades que sí las conservan deben ser, prima facie, respetadas. Los pueblos que no lo hacen se enfrentan a un direccionamiento mayor de las leyes, pues resulta ajeno al orden constitucional y legal que algunos ciudadanos en ciertas comunidades, ante la carencia de claridad jurídica, puedan quedar relegados a los extramuros del derecho, por efecto de una imprecisa o inexistente delimitación de la normatividad llamada a regular sus derechos y obligaciones.

Otra de las reglas de interpretación precisa que las normas legales imperativas (de orden público) de la república priman sobre los usos y costumbres de las comunidades y pueblos indígenas, siempre y cuando protejan directamente un valor constitucional superior al principio de diversidad étnica y cultural. Ha dicho la Corte Constitucional que en los casos relacionados con la jurisdicción especial indígena ( $\mathrm{CP}$, art. 246) y el autogobierno, encomendadas a los cabildos indígenas (CP, art. 330), las funciones deben ejercerse según sus usos y costumbres, pero respetando las leyes imperativas sobre la materia que protejan valores constitucionales superiores. 
Así las cosas, sobre los usos y costumbres de una comunidad o pueblo indígena, la Corte Constitucional señala que priman sobre las normas legales dispositivas. Pese a que por regla general, la sujeción a la Constitución y a la ley es un deber de todos los nacionales (cP, arts. 4, 6 y 95), dentro de los que se incluyen evidentemente los indígenas, no sobra subrayar que la Carta prevalece. Esta regla no significa la aceptación de la costumbre contra legem, sino el reconocimiento de la Carta como prevalente frente a normas dispositivas, esto es no imperativas, como aquellas que en materia civil le conceden un margen amplio a la autonomía de la voluntad privada. En este sentido, la Corte Constitucional (T-254/9442) señaló que, mutatis mutandis, ello fundamenta la prevalencia de los usos y costumbres en la materia sobre normas que sólo deben tener aplicación en ausencia de una autorregulación por parte de las comunidades y pueblos indígenas.

Es indispensable tener presente que la Corte Constitucional ha señalado más recientemente que dicho principio no puede concebirse como una prescripción dirigida a los jueces para dar mayor protección a la autonomía de ciertos grupos indígenas (los de mayor conservación o aislamiento), sino como una descripción sobre el estado actual de los usos y costumbres de los pueblos aborígenes, que tiene como consecuencia la mayor o menor necesidad de "traducción de los sistemas jurídicos tradicionales en categorías occidentales o viceversa" (ccc, T-617/10). De esa forma, frente a comunidades con alto grado de conservación de sus costumbres, el juez debe ser más cauteloso y valerse de conceptos de expertos para aproximarse al derecho propio, mientras que este procedimiento puede efectuarse de manera menos exigente frente a comunidades que hayan adaptado categorías y formas del derecho mayoritario (ccc, T-617/10). ${ }^{43}$

\footnotetext{
${ }^{42}$ Acción de tutela contra la directiva del cabildo de la comunidad indígena de El Tambo, localizada en el municipio de Coyaima, departamento del Tolima, que decidió expulsar y desterrar al actor junto con su familia de la comunidad donde residía y laboraba, por la supuesta comisión del delito de hurto. La corte tutela el derecho fundamental al debido proceso de solicitante y del derecho a la integridad física a sus hijos y, en consecuencia, ordena a las miembros del cabildo acoger nuevamente en la comunidad, bajo responsabilidad de esta, al actor y a su familia, mientras se procede nuevamente a tomar la decisión a que haya lugar por los hechos, sin que esta pueda involucrar a su familia dentro de un juicio que respete las normas y procedimientos de la comunidad, pero con estricta sujeción a la constitución.

${ }^{43}$ Acción de tutela contra la Sala Disciplinaria del Consejo Superior de la Judicatura interpuesta por el gobernador y representante legal del cabildo indígena de Túquerres con el fin de obtener protección a los derechos fundamentales a la autonomía y diversidad cultural de la comunidad y a los derechos cons-
} 
Sin embargo, asegura este alto tribunal que ese grado de conservación cultural no puede llevar al juez, ni a ningún otro operador judicial, a desconocer las decisiones autónomas de cada comunidad, incluidas aquellas dirigidas a iniciar un proceso de recuperación de tradiciones, o a separarse de algunas de sus tradiciones:

La decisión de una comunidad indígena con un grado escaso de conservación de sus tradiciones, en el sentido de iniciar un proceso de recuperación cultural debe ser respetada, de la misma forma y en el mismo grado, que la decisión de otra comunidad, con alta conservación de sus tradiciones, de incorporar formas sociales propias de la cultura mayoritaria [...] En ningún caso [...] está permitido al intérprete desconocer la autonomía de las comunidades; lo que sucede, por así decirlo, es que la necesidad de traducción de las instituciones indígenas al derecho mayoritario - o viceversa- es de mayor entidad en el segundo caso. (ccc, T- 514/0944 y T-617/10)

Con respecto a la proporcionalidad, dice que en caso de que deba optarse por una limitación a la autonomía de las comunidades indígenas sobre la base de los presupuestos constitucionales permisibles, la medida que se tome debe ser la menos gravosa para la autonomía de dichas comunidades étnicas. En consecuencia, se deberán revisar las características específicas de la comunidad de la que se trata, puesto que no todas le otorgarán la misma importancia a las posibilidades de determinar cada uno de sus asuntos.

Finalmente, en relación con las reglas de interpretación, la Corte Constitucional afirma que pueden concebirse posibles restricciones del derecho a la propiedad colectiva de las comunidades indígenas. Reconoce que en situaciones concretas y específicas, es posible llegar a consolidar límites por

titucionales al debido proceso y la diversidad étnica de uno de sus miembros en un caso presuntamente relacionado con el abuso sexual de una menor de edad (14 años). La Corte Constitucional solicita a las autoridades tradicionales del resguardo que evalúen, en el marco del derecho propio, la posibilidad de contar con la colaboración de taitas y médicos tradicionales, que brinden pautas de solución al conflicto.

${ }^{44}$ Acción de tutela contra gobernador y representante legal del resguardo índígena Chenche Buenos Aires Tradicional (Coyaima, Tolima), con el fin de obtener protección constitucional a sus derechos fundamentales al debido proceso, la igualdad, la integridad étnica y cultural, la identidad indígena, el derecho adquirido a participar de los beneficios del Sistema General de Participaciones y la Jurisdicción Especial Indígena. 
razones de orden público y de seguridad nacional al derecho a la propiedad colectiva de las comunidades indígenas (ccc, T-973/09).

\subsubsection{Derecho a la autodeterminación y a la autonomía ${ }^{45}$}

Anaya $(2005,136-137)$ señala que ninguna consideración acerca de los derechos de los pueblos indígenas en el derecho internacional sería completa sin una consideración del principio de autodeterminación — recogida en varios instrumentos internacionales como la libre determinación-, un principio fundamental del ordenamiento jurídico internacional contemporáneo. La autodeterminación se basa en la idea de que todos los sectores de la humanidad tienen el mismo derecho a controlar su propio destino.

En esa línea, los pueblos indígenas tienen derecho a la libre determinación, en virtud del cual establecen libremente su condición política y su desarrollo económico, social y cultural. Sin embargo, el Convenio 169 de la oIT no menciona explícitamente el tema de libre determinación, aunque sí la participación,la consulta, autogestión y el derecho de los pueblos indígenas a decidir sus prioridades como mecanismos importantes para la concreción de este derecho (оIт 2009, 37), tal cual está reflejado en la DNUDPI que se refiere explícitamente al tema. ${ }^{46}$

Los Estados reconocen que los pueblos indígenas tienen derecho a determinar libremente su estatus político y a promover su desarrollo económico, social y cultural. Consecuentemente, tienen derecho a la autonomía o autogobierno en lo relativo a cultura, religión, educación, información, medios de comunicación, salud, habitación, empleo, bienestar social, actividades económicas, administración de tierras y recursos, ambiente e ingreso de no miembros, entre otros, así como en sus asuntos internos, locales y en los medios usados para financiar estas funciones autónomas (onIC 2007a, 43).

\footnotetext{
45 En relación con el derecho a la autodeterminación y a la autonomía se sugiere ver la siguiente jurisprudencia de la Corte Constitucional: T-254 de 1994, C-139 de 1996, T-349 de 1996, su-510 de 1998, C-795 de 2000,T-606 de 2001, T-1127 de 2001, C-370 de 2002, T-048 de 2002, C-063 de 2003, T-379 de 2003,T-552 de 2003,T-1294 de 2005,T-704 de 2006, T-979 de 2006, C-921 de 2007,T-009 de 2007, T-123 de 2007, T-703 de 2008, T-1026 de 2008, T-1253 de 2008, T-113 de 2009, T-514 de 2009, T-903 de 2009, T-973 de 2009, T-617 de 2010 y T-693 de 2011.

46 Artículo 3: "Los pueblos indígenas tienen derecho a la libre determinación. En virtud de ese derecho determinan libremente su condición política y persiguen libremente su desarrollo económico, social y cultural". Artículo 4: "Los pueblos indígenas, en ejercicio de su derecho de libre determinación, tienen derecho a la autonomía o el autogobierno en las cuestiones relacionadas con sus asuntos internos y locales, así como a disponer de los medios para financiar sus funciones autónomas".
} 
En este mismo sentido, Ibarra $(2007,38)$ considera que tanto por la naturaleza de sus demandas como por razones normativas la mejor forma de acomodar a los pueblos indígenas dentro del Estado, en términos de justicia, es a través del reconocimiento de diversos grados de autonomía según las necesidades particulares de los pueblos. Para este autor, dicho régimen autonómico debe contener los siguientes elementos:

a) Un conjunto de derechos que garanticen la igualdad de los miembros de los pueblos indígenas frente a la sociedad predominante para el ejercicio de los derechos y las libertades básicas, pues no hay que perder de vista que tradicionalmente esos pueblos se han enfrentado en condiciones de franca desventaja a la cultura predominante del Estado nacional, lo que les ha impedido disfrutar, en igualdad de condiciones, de aquellos derechos y libertades básicas de que disponen los Estados liberales.

b) Asimismo, se deberán pactar con los pueblos indígenas ciertas competencias autonómicas que estén dirigidas a permitir que éstos reproduzcan su cultura societal [...]

c) [...] Un régimen autonómico deberá considerar siempre una base territorial suficiente, sin la cual no estaríamos en condiciones de permitir que los pueblos indígenas reproduzcan su cultura, pero sobre todo no estaremos en posibilidades de que cuenten con la mínima base económica para su sustento y desarrollo [...].

d) Finalmente, un régimen autonómico debe proveer el autogobierno, que es indispensable para garantizar no sólo el ejercicio de las facultades autonómicas necesarias para que los pueblos indígenas reproduzcan su cultura $[\ldots]$

En esta delimitación de derechos, el autor explica que la autonomía debe concebirse como una forma de ejercicio de la autodeterminación y argumenta que

están en un error quienes consideran que cuando los pueblos indígenas exigen autodeterminación, lo que están exigiendo es la secesión o la independencia del Estado en el cual se encuentran ubicados. En efecto, la autodeterminación no tiene como única posibilidad 
la secesión, pues la autonomía puede ser una de sus modalidades, y en este sentido, lo que los pueblos indígenas están demandando es el reconocimiento y la creación de las instituciones propias de la autonomía. (Ibarra 2007, 44)

Se entiende entonces que el reconocimiento de la autonomía es necesario para decidir el presente y el futuro de los pueblos indígenas, pues esta se basa en lo territorial, lo identitario y lo propio. La exigencia del respeto a la autonomía, además, conlleva el reconocimiento de los sistemas de autoridad y gobierno de esos pueblos y de los procesos mediante los cuales toman decisiones; así lo plantea el Convenio 169 al consagrar que deben reconocerse las aspiraciones de los pueblos indígenas por asumir el control de sus propias instituciones, formas de vida y desarrollo económico, al igual que por mantener y fortalecer sus identidades, lenguas y religiones. Esta también significa que las comunidades deben tener mayor control sobre su vida y futuro y que el Estado debe proporcionar los medios y recursos necesarios para tales efectos, a fin de que ellos logren participar en los procesos de toma de decisiones y tengan la posibilidad de autoidentificarse como parte de los pueblos indígenas, tal como lo señala la guía de aplicación del Convenio 169 de la OIT.

Para estas comunidades, el derecho a la autonomía significa el ejercicio de sus formas de gobierno, justicia, educación, salud, reproducción social y económica, entre otros, para regular su reproducción étnica y sus cambios culturales. Implica además el manejo, el control y administración de los recursos naturales, territoriales, de los derechos consuetudinarios y otros elementos que permiten pervivir al hombre en su estado natural y con su cultura ancestral. Así las cosas, los pueblos indígenas claman adicionalmente por la autonomía administrativa, fiscal y financiera en el manejo de sus territorios, para poder además controlar, vigilar y organizar su vida social y política al interior de los resguardos y tener la posibilidad de rechazar las políticas impuestas desde afuera (Resguardo de Vitoncó, sin publicar). Lo anterior tiene que ver con la pervivencia, la unidad y la solidaridad al interior de estas comunidades, pretendiendo un desarrollo integral que se encamine hacia la autonomía económica, política y cultural y el pleno ejercicio del derecho propio. 
Para Grueso Castelblanco (2008, 22),

\begin{abstract}
el derecho a la autonomía de los pueblos implica el resolver las contradicciones y asuntos básicos que limitan sus libertades fundamentales, entre ellas, la falta de movilidad dentro del territorio por la presencia de actores armados ilegales, la falta de seguridad y soberanía alimentaria por la expansión de monocultivos, la vulneración de la gobernabilidad de las autoridades tradicionales y representativas de los pueblos. Si a esta discusión se agrega la variable ambiental por la función de conservación de los territorios colectivos de los grupos étnicos, el debate se amplía a los derechos de todos los ciudadanos a un ambiente sano [...] De estos debates, se derivan desafíos que es necesario resolver [...] los que implican en sí mismos la revisión de métodos, roles y responsabilidades en cabeza de las instituciones del Estado frente a contextos de conflicto y condiciones de exclusión, discriminación y pobreza.
\end{abstract}

\title{
2.1.2.2.1.Jurisprudencia sobre el derecho a la autonomía
}

Así, para el tribunal constitucional la autonomía indígena se garantiza en tres ámbitos de protección diversos, los cuales se encuentran ligados a distintos factores de interacción según se trate de asuntos internos o externos a la comunidad (ccc, T-973/09):

a) En el ámbito externo, el respeto por la autonomía de las comunidades y pueblos indígenas exige reconocer el derecho de tales grupos a participar en las decisiones que los afectan. Ese reconocimiento supone que en las relaciones entre estos pueblos y el Estado, la consulta previa juega un rol necesario para asegurar que las aspiraciones culturales, espirituales y políticas de los pueblos indígenas sean consideradas en el ejercicio de las demás atribuciones y competencias de la Administración. Por lo tanto, estos pueblos tienen el derecho a ser consultados previamente con relación a las decisiones que los afecten, en los términos que determine la Constitución y la ley.

Un segundo ámbito de protección, también externo, tiene que ver con la participación política de estas comunidades en la esfera de 
representación nacional, es decir, en el Congreso. Así, los pueblos indígenas tienen el derecho de participar en la circunscripción especial electoral prevista para ellas, de acuerdo con la Constitución Política.

b) Con respecto al reconocimiento de la autonomía en el orden interno, la Corte Constitucional ha señalado que este supone el derecho de las comunidades y pueblos indígenas a:

(i) Decidir su forma de gobierno (cP, art. 330).

(ii) Ejercer funciones jurisdiccionales en su ámbito territorial (CP, art. 246).

(iii) Ejercer el derecho de propiedad de sus resguardos y territorios, con los límites que señalen la Constitución y la ley. En este sentido, la autonomía política y jurídica, relacionada con la autogestión territorial, actúa como un instrumento de reafirmación de la identidad de las comunidades y pueblos indígenas, las que, mediante el ejercicio de sus prácticas tradicionales, avanzan en el fortalecimiento de sus autoridades internas y en el auto-reconocimiento de sus espacios de expresión colectiva.

Es importante señalar que la Corte Constitucional ha mencionado que el derecho de una comunidad a la autonomía política es de carácter permanente e imprescriptible (ccc, T-979/06, T-254/94, T-811/04 y T-973/09), resaltando que las facultades de las comunidades y pueblos indígenas en materia de política interna involucran entonces dentro de su ámbito territorial, entre otros, los siguientes derechos:

a) El de escoger la modalidad de gobierno que las debe regir.

b) El derecho a consolidar y determinar sus instituciones políticas y sus autoridades tradicionales.

c) La posibilidad de establecer de manera propia, y conforme a sus usos y costumbres y a lo que señale la ley, las funciones que les corresponde asumir a tales autoridades y

d) La determinación de los procedimientos y requisitos de elección de sus autoridades, así como la modificación y actualización de tales normas. $\mathrm{Al}$ respecto, si bien a las autoridades indígenas les 
corresponde actuar conforme lo han hecho en el pasado, dado que sus usos y costumbres son el eje de su autoridad y de la cohesión social de sus pueblos, las comunidades indígenas en su conjunto pueden determinar, modificar y actualizar las disposiciones y procedimientos de elección, en virtud a sus potestades legislativas internas que poseen.

e) También pueden definir las instancias internas de resolución de sus conflictos electorales. Todo lo anterior, sin desconocer los límites que señalen la Carta Política y el legislador.

Por último, sobre los alcances de la autonomía, la jurisprudencia constitucional señala que la pérdida de ciertos aspectos de la cultura tradicional, usos y costumbres, modos de producción, formas de relacionarse con el ambiente y visiones religiosas no puede servir de fundamento para disminuir la capacidad de la comunidad o pueblo indígena de decidir autónomamente sobre sus asuntos (ccc, T-903/0947). Esa posibilidad sería incompatible con los principios constitucionales de no discriminación e igualdad y respeto por la dignidad de todas las culturas. Así, la decisión de una comunidad o pueblo indígena con un grado escaso de conservación de sus tradiciones, en el sentido de iniciar un proceso de recuperación cultural, debe ser respetada de la misma forma y en el mismo grado que la decisión de otra comunidad, con alta conservación de sus tradiciones, de incorporar formas sociales propias de la cultura mayoritaria.

\footnotetext{
${ }^{47}$ Acción de tutela presentada por una mujer indígena, contra el cabildo gobernador de la comunidad y el Consejo de Mayores de la Organización Indígena Kankuama, con el fin de obtener protección constitucional a los derechos fundamentales al debido proceso, a elevar peticiones respetuosas y a la estabilidad laboral reforzada. La Corte Constitucional protege el derecho fundamental al debido proceso de la peticionaria, que considera vulnerado por las autoridades del resguardo al decidir desvincular a la actora del cargo de coordinadora del grupo de mujeres de la comunidad por no cumplir la decisión del consejo de mayores y, además, ordena a las autoridades que se proceda a discutir sobre su permanencia como coordinadora, garantizando la participación de la afectada y del grupo de mujeres o grupo de artesanas de la comunidad.
} 


\subsection{Limites a la autonomía}

Para la Corte Constitucional (T-349/9648), el intérprete de la maximización de la autonomía de las comunidades y pueblos indígenas y, por tanto, la de la minimización de las restricciones a las indispensables para salvaguardar intereses de superior jerarquía supone que al ponderar los intereses que puedan enfrentarse en un caso concreto al interés de la preservación de la diversidad étnica de la nación sólo serán admisibles las restricciones a la autonomía de las comunidades cuando se cumplan las siguientes condiciones:

a) Que se trate de una medida necesaria para salvaguardar un interés de superior jerarquía (verbigracia: la seguridad interna).

b) Que se trate de la medida menos gravosa para la autonomía que se les reconoce a las comunidades étnicas.

Específicamente, como límite a la autonomía, la Corte Constitucional (T-903/09) hace referencia al 'núcleo duro' de los derechos, el cual se constituye en un límite absoluto que trasciende cualquier ámbito autonómico de las comunidades o pueblos indígenas. Cualquier decisión que desconozca el derecho a la vida, lesione la integridad de una persona o transgreda las prohibiciones de tortura y servidumbre está constitucionalmente prohibida, aunque la evaluación de una eventual vulneración, especialmente en cuanto a la integridad personal y el debido proceso, debe realizarse a la luz de la cultura específica en que se presenten los hechos.

Por otro lado, la Corte Constitucional ha aceptado que se generen limitaciones a la autonomía de las autoridades indígenas, cuando estas se dirigen a evitar la realización o consumación de actos arbitrarios que lesionen gravemente la dignidad humana, que afecten el núcleo esencial de los derechos fundamentales de los miembros de la comunidad o de terceros, o que se encuentren en contraposición con otros principios o derechos avalados por la Constitución, las normas internacionales que forman parte del bloque de constitucionalidad y la ley (ccc, su-510/98 y T- 973/09).

${ }^{48}$ Acción de tutela interpuesta por un indígena embera-chamí en contra la Asamblea General de Cabildos en Pleno de la comunidad y del cabildo mayor único de Risaralda, por vulneración de sus derechos al debido proceso, a la defensa, a la vida y a la integridad física. Intenta que se le permita regresar. La Corte Constitucional decide consultar a la comunidad reunida en pleno sobre su disponibilidad para juzgar nuevamente al sindicado, conforme a sus prácticas tradicionales. 
La autonomía indígena que se desprende del principio de diversidad étnica y cultural encuentra límites en otros principios constitucionales de igual categoría y en todo aquello que resulte intolerable por atentar contra los bienes más preciados del hombre y su dignidad, es decir, aquellos derechos que han sido reconocidos como intangibles por los tratados internacionales de derechos humanos y frente a los que existe un consenso intercultural, como es el caso de:

(a) El respeto al derecho a la vida.

(b) La prohibición de la tortura y de la esclavitud.

(c) La responsabilidad individual por los actos propios.

(d) La legalidad del procedimiento, de los delitos y de las penas. ${ }^{49}$

Así, si bien debe reconocerse que en determinadas circunstancias los derechos fundamentales individuales pueden imponer límites a los derechos de las comunidades, también debe tenerse presente que existen ámbitos de la autonomía en los que la intervención externa es especialmente nociva. En consecuencia, lo más indicado para el juez constitucional es promover el diálogo interno de la comunidad, a fin de que los conflictos se resuelvan en el marco de su cosmovisión, normas, usos y costumbres (ccc, T-903-09).

\subsubsection{Derecho al territorio ${ }^{50}$}

Rodolfo Stavenhagen, en su informe presentado ante la Comisión de Derechos Humanos - ONU- (Stavenhagen 2002), ${ }^{51}$ resalta que desde tiempos inmemoriales los indígenas han mantenido una relación especial con la tierra, que es su medio de vida y de sustento y la base de su existencia misma como comunidades territoriales identificables. Señala que el derecho a poseer, ocupar

${ }^{49}$ Sobre este particular se sugiere ver ccc, T-973/09, T-349/96, T-349/06, su-510/98 y T-778/05.

${ }^{50}$ En relación con el derecho al territorio se sugiere ver la siguiente jurisprudencia de la Corte Constitucional: T-188 de 1993, T-257 de 1993, T-380 de 1993, C-104 de 1995, C-138 de 1996, su039 de 1997, T-525 de 1998, T-652 de 1998, su-510 de 1998, T-634 de 1999, C-418 de 2002, C-891 de 2002, T-955 de 2003, su-383 de 2003, C-180 de 2005, T-703 de 2008, T-1105 de 2008, T-013 de 2009, T-514 de 2009, T-617 de 2010,T-235 de 2011 y T-282 de 2011.

${ }^{51}$ Informe presentado por el relator especial sobre la situación de los derechos humanos y las libertades fundamentales de los indígenas, sr. Rodolfo Stavenhagen, ante la Comisión de Derechos Humanos en su $50^{\circ}$ período de sesiones (2002). 
y utilizar la tierra es inherente a la idea que tienen los pueblos indígenas de sí mismos y, en general, es a la comunidad local, la tribu, la nación o el grupo indígena a quien se confiere ese derecho. Para el ex relator especial, estas comunidades mantienen vínculos históricos y espirituales con sus tierras de origen, espacios geográficos en los que florece la sociedad y donde la cultura puede transmitirse de generación en generación.

En lo que tiene que ver con el conjunto de derechos que se han diseñado en las actuales democracias en función de la pertenencia a un grupo específico, que puede ser una minoría nacional o un grupo étnico, según las categorías que utiliza Kymlicka, ${ }^{52}$ se pueden diferenciar los derechos de autogobierno que reivindican la autonomía política o jurisdicción territorial, que busca asegurar la integridad y el libre desarrollo cultural de un conglomerado humano concreto.

Sin embargo, en muchas partes del mundo, la esperanza de llegar a tener poderes políticos es prácticamente una utopía y el objetivo más inmediato es simplemente asegurar la base territorial existente para que no sufra mayores deterioros a manos de los colonos o de los explotadores de sus recursos. De hecho, un reciente estudio demostró que, en la actualidad, la principal causa de los conflictos étnicos en el mundo es la lucha de los pueblos indígenas para proteger sus derechos territoriales. (Kymlicka 1996, 51)

Por su parte, territorio es la extensión de tierra perteneciente a una nación, región, provincia, etc. El conglomerado social política y jurídicamente constituido, que es la población, está asentado sobre un determinado territorio, dentro del cual se ejerce el poder del Estado. El territorio indígena se constituye en el lugar donde los pueblos indígenas desarrollan su vida, su cultura, su economía y sus propias formas desarrollo, independientemente de que tengan o no título de propiedad estatal. Estos comprenden no sólo los espacios habitados y explotados, sino también aquellos que constituyen

\footnotetext{
${ }^{52}$ Este filósofo canadiense plantea en términos generales que el multiculturalismo liberal pretende realzar la importancia de la identidad cultural protegiendo las diversas minorías nacionales y étnicas, pero garantizando la vigencia de ciertos principios liberales básicos. Luego, el Estado debe adoptar políticas públicas destinadas a que los miembros de los diversos grupos étnicos y nacionales puedan expresar y promover su propia cultura e identidad, pero rechazando aquellos que busquen imponerla (Villavicencio Miranda 2012,33).
} 
el ámbito tradicional de sus actividades económicas, sociales y culturales. Es diferente el concepto de territorio al de tierra. Este último es un derecho de todo ser humano, en forma individual o colectiva, mientras que el territorio es un concepto más amplio que además se refiere a una figura sociopolítica junto con las formas de relación y apropiación de la tierra y los recursos naturales, que responden a las cosmovisiones concretas y particulares, para nuestro estudio, de los pueblos y comunidades indígenas.

El ejercicio del derecho territorial le permite a una comunidad o pueblo indígena acceder colectivamente a sus recursos naturales, controlar los procesos sociales, culturales, políticos y económicos que ocurran dentro de ese espacio, puesto que tienen derecho a poseer, desarrollar, controlar y utilizar sus tierras y territorios, que es lo más importante para ellos. Sin territorio, todo se desvanece, pierde fuerza y no hay donde expresar la cultura.

En este contexto, Colombia, como nación multiétnica y pluricultural, ha establecido que los pueblos indígenas tienen derecho a decidir sobre sus territorios. Para ello, es fundamental su reconocimiento, pues, tal y como lo señala la Corte Constitucional, sin este los derechos a la identidad cultural y a la autonomía son sólo reconocimientos formales (ccc, T-188/9353). Es deber del Estado respetar la importante relación existente entre las culturas y sus valores espirituales con las tierras y territorios, en especial los aspectos colectivos que en dicha relación representa la totalidad del hábitat de las regiones que los pueblos ocupan o utilizan de alguna manera.

Es así como el derecho de propiedad y posesión sobre las tierras y territorios que tradicionalmente ocupan estos pueblos implica además el deber de tomar medidas para salvaguardar el derecho a utilizar las que no estén exclusivamente ocupadas por ellos, pero a las que hayan tenido ancestralmente acceso para sus actividades tradicionales y de subsistencia; adicionalmente, se deben respetar las modalidades de transmisión de los derechos de propiedad que han sido establecidas por dichos pueblos (Convenio 169 de la OIT).

En este sentido, el Estado debe tomar las medidas necesarias para determinar las tierras ocupadas y garantizar la protección efectiva de sus derechos

\footnotetext{
${ }^{53}$ Acción de tutela presentada por los miembros de la comunidad indígena Paso Ancho, asentada en la vereda de Chicuambe, municipio de Ortega, departamento del Tolima, como mecanismo transitorio para evitar un perjuicio irremediable contra el Instituto Colombiano de Reforma Agraria, Incora. La Corte Constitucional concede la tutela y, en consecuencia, ordena al Incora, seccional Tolima, la realización de los estudios socioeconómicos y jurídicos tendientes a la constitución de uno o varios resguardos.
} 
de propiedad y posesión; debe establecer procedimientos adecuados para solucionar las reivindicaciones formuladas por estos pueblos y, al mismo tiempo, mediante los programas agrarios, debe garantizar las condiciones para la asignación de tierras tradicionales, cuando las que dispongan sean insuficientes para asegurar los elementos de su existencia normal o para hacer frente a su posible crecimiento numérico. Adicionalmente, el Convenio 169 consagra que a pesar de estar establecido que los pueblos no deberán ser traslados de las tierras y territorios que ocupan, cuando excepcionalmente el traslado y la reubicación se consideren necesarios sólo deberán efectuarse con su consentimiento, ${ }^{54}$ dado libremente y con pleno conocimiento de causa. En todo caso, estos pueblos tienen el derecho de regresar cuando dejen de existir las causas que motivaron su traslado y reubicación. Si esto no fuere posible, tienen derecho a recibir indemnización por cualquier pérdida o daño sufrido como consecuencia de su desplazamiento.

Según la guía de aplicación del mencionado Convenio 169 (огт 2013), el reconocimiento de derechos especiales para los pueblos indígenas sobre las tierras tiene por objeto asegurarles una base estable para sus iniciativas económicas, sociales y culturales, y su sobrevivencia futura. No se trata de crear un Estado paralelo, porque el convenio está explícitamente orientado a acciones en el marco del Estado en el que los pueblos indígenas viven.

Por su parte, la DNUDPI establece que los pueblos indígenas tienen derecho a las tierras, territorios y recursos que tradicionalmente han poseído, ocupado o de otra forma utilizado o adquirido, los cuales pueden poseer, utilizar, desarrollar y controlar. Dicho reconocimiento implica que se debe respetar debidamente las costumbres, las tradiciones y los sistemas de tenencia de la tierra de los pueblos indígenas.

\subsection{Jurisprudencia sobre el derecho al territorio}

El tribunal constitucional define el territorio indígena como el conjunto de áreas poseídas por una parcialidad y que comprende, además de las habitadas y explotadas, aquellas que constituyen el ámbito tradicional de sus actividades económicas y culturales. Asegura la Corte Constitucional que la constitución de resguardos se justifica en la medida en que el usufructo por la explotación

\footnotetext{
${ }^{54}$ Para poder ordenar el traslado y la reubicación, además de la consulta previa, se debe obtener el consentimiento como requisito indispensable (artículo 16 del Convenio 169 de la ОIт).
} 
de la tierra revierta en las comunidades indígenas que son sus propietarias. Si por cualquier vía se priva a la comunidad de tales beneficios y se permite que otros agentes sociales los obtengan, puede afirmarse que se está perdiendo una de las razones para mantener la presunta propiedad colectiva del resguardo (ccc, su-510/98).

En la sentencia T-188 de 1993, la Corte Constitucional resalta la especial relación de las comunidades y pueblos indígenas con los territorios que ocupan, no sólo por ser estos su principal medio de subsistencia, sino porque constituyen un elemento integrante de la cosmovisión y la religiosidad de los pueblos aborígenes. En consecuencia, presupone el reconocimiento del derecho de propiedad sobre los territorios tradicionales ocupados y los que configuran su hábitat. Se debe resaltar que, además, la Corte Constitucional ha enfatizado que el concepto de territorio no se restringe a la ubicación geográfica de una comunidad o un resguardo indígena, sino que se asocia al concepto de ámbito cultural de la comunidad (ccc, T-1105/0855 y T-235/1156).

Según esta corporación (ccc, T-188/93), el constituyente de 1991, con el fin de proteger la integridad territorial y cultural de los pueblos indígenas como colectividad sujeta a tratamiento especial, estableció la propiedad colectiva de los resguardos y de las tierras comunales de las etnias. El derecho de

55 Una joven indígena instaura acción de tutela contra la Universidad del Cauca porque considera que desconoció sus derechos constitucionales fundamentales a la educación, y a la igualdad por cuanto todas las personas tienen derecho a estar situadas en posiciones que [les] permitan participar y competir en igualdad de condiciones, siendo ese el caso de concursar por el cupo indígena. La Corte Constitucional ordena a la universidad que, dadas las circunstancias del caso en concreto, en un término de 48 horas adopte las medidas indispensables con el fin de adicionar un cupo especial para bachiller indígena destinado a beneficiar a la peticionaria, de modo que ella pueda adelantar estudios de Contaduría Pública en ese establecimiento de educación superior. Advierte que lo resuelto no significa de manera alguna que la universidad pueda retirarle la beca a otro constantes nstituyen en nflictosis.onstitucionales y legales. cides, lver conflictos. los derechos de participaci recursos natu bachiller indígena que ya fue beneficiado con ella.

${ }^{56} \mathrm{La}$ gobernadora y representante legal de la comunidad indígena radicada en el cañón del río Pepitas, municipio de Dagua (Valle del Cauca), interpuso acción de tutela en nombre de la comunidad, con el fin de obtener amparo constitucional a los derechos fundamentales a la vida, la integridad física y la vivienda digna de los miembros de la comunidad, que considera amenazados por la actitud omisiva de la alcaldía municipal de Dagua y el Clopad del municipio frente a la grave afectación que produjo la ola invernal de 2008 en los caminos aledaños al resguardo, y en algunas edificaciones de la comunidad. La Corte Constitucional concede el amparo a los derechos fundamentales al territorio colectivo del resguardo Pepitas; a la vivienda digna de miembros del resguardo (identificables); a la educación de los menores del resguardo del río Pepitas; y a la prevención y atención de desastres de la comunidad indígena del río Pepitas, en relación con la seguridad e integridad personal de los miembros del resguardo. 
propiedad sobre los territorios indígenas reviste la mayor importancia dentro del esquema constitucional, pues resulta ser esencial para la preservación de las culturas y valores espirituales de los pueblos que dentro de ellos se han asentado durante siglos. El dominio comunitario sobre tales territorios debe ser objeto de especial protección por parte de la ley y de las autoridades. Considera también que el desconocimiento de este derecho y de sus consecuencias jurídicas quebrantaría de manera grave la identidad misma de las comunidades, implicaría ruptura del principio constitucional que las reconoce y, en el fondo, llevaría a destruir la independencia que las caracteriza, con notorio daño para la conservación y adecuado desarrollo de sus culturas y creencias. En este sentido, si la propiedad colectiva sobre el territorio indígena es un derecho del pueblo correspondiente, la regla correlativa es el respeto del mismo por parte del Estado y de los particulares (ccc, T-525/9857).

El Alto Tribunal constitucional resalta que la posesión ancestral de las tierras que habitan las comunidades o pueblos indígenas es un elemento importante para la titularidad del derecho al territorio colectivo. Advierte que cuando pierde esa posesión por motivos ajenos a su voluntad (como por definición sucede en los desplazamientos forzados), el Estado mantiene la obligación de propender por la recuperación de su territorio, de velar por que se haga efectivo el derecho al retorno y, si no es posible, de iniciar los trámites y adoptar las medidas necesarias para que esos pueblos obtengan tierras aptas para mantener sus tradiciones y desarrollar su proyecto de vida (ccc, T-282/11).

De manera permanente, la jurisprudencia constitucional plantea que el derecho al territorio es de primer orden. Así, reitera el carácter fundamental del derecho a la propiedad colectiva de los grupos étnicos sobre sus territorios, no sólo por lo que significa para su supervivencia, sino porque él hace parte de las cosmogonías amerindias y es substrato material necesario para el desarrollo de sus formas culturales características.

\footnotetext{
${ }^{57}$ Por conducto de su gobernador, la parcialidad indígena de Ricaurte — municipio de Páez, departamento del Cauca - instauró acción de tutela contra el Ministerio del Interior -Dirección General de Asuntos Indígenas-, con el objeto de reclamar la que, según dijo, constituía violación del derecho indígena a la propiedad de la tierra del resguardo. Según los accionantes, a partir de 1994 se han dirigido en numerosas ocasiones, verbalmente y por escrito, al Incora, regional Cauca, y al Ministerio del Interior, para que se certifique si Ricaurte es un resguardo legalmente constituido, tal como lo acreditan las pruebas aportadas por los diferentes gobernadores. La corte no considera violados los derechos de esta comunidad.
} 
Dada la protección constitucional del principio de diversidad étnica y cultural, el derecho fundamental a la propiedad colectiva de los grupos étnicos lleva implícito un derecho a la constitución de resguardos en cabeza de las comunidades indígenas. Ahora bien, para la corte, las actuaciones administrativas orientadas a constituir los resguardos deben partir del respeto por el derecho a la personalidad de cada uno de los pueblos (ccc, T-652/9858).

\subsection{Limites al derecho al territorio}

La ley define como territorios indígenas las áreas poseídas en forma regular y permanente por una comunidad, parcialidad o grupo indígena de conformidad con lo dispuesto en la Ley 21 de 1991 y las demás leyes que la modifiquen, amplíen o sustituyan (ccc, T-405/9359 y C-418/0260). Como límite a este derecho, la Corte Constitucional sólo ha hecho prevalecer otro tipo de interés sobre el derecho fundamental de propiedad colectiva de las comunidades y pueblos indígenas sobre sus resguardos, cuando se trataba del interés de la

${ }^{58}$ Acciones de tutela contra el presidente de la república, los ministros del Interior, Agricultura, Medio Ambiente, y Minas y Energía, la Alcaldía Municipal de Tierralta (Córdoba) y la empresa Multipropósito Urrá S.A. - E. S. P., por la presunta violación de los derechos fundamentales del pueblo embera-katío del Alto Sinú. La Corte Constitucional tutela los derechos fundamentales a la supervivencia, a la integridad étnica, cultural, social y económica, a la participación y al debido proceso del pueblo embera-katío del Alto Sinú y efectúa diversas órdenes a varias instituciones, con el fin de hacer efectivos sus derechos.

${ }^{59}$ Las comunidades indígenas del Medio Amazonas instauran acción de tutela contra el Ministerio de Defensa Nacional y la Misión Aérea de los Estados Unidos, por cuanto a su juicio se les están vulnerando y amenazando los derechos a la comunidad indígena "por las labores de instalación de las bases militares norteamericanas y colombianas al interior de los predios del resguardo de Monochoa, propiedad colectiva de los grupos étnicos huitoto y muinane". Señalan que existe una violación directa por la actual ocupación del resguardo por parte de tropas norteamericanas para instalar un radar de la DEA y manifiestan que existe una amenaza a sus derechos fundamentales por los planes de construir una base de la Fuerza Aérea en la zona. Consideran que se les están violando sus derechos fundamentales a la existencia como pueblos indígenas y el derecho a la igualdad y dignidad con las otras culturas; el derecho a la integridad cultural, social y económica de las comunidades indígenas; el derecho a la autonomía y a las autoridades tradicionales; el derecho a los resguardos y a los territorios tradicionales y comunales. Igualmente, estiman vulnerada la Ley 21 de 1991. La Corte Constitucional concede la tutela impetrada por la comunidad indígena del Medio Amazonas en cuanto a la protección de su derecho al ambiente sano.

${ }^{60}$ Correspondiente a la acción pública de inconstitucionalidad mediante la cual se demandó el artículo 122 de la Ley 685 de 2001, "por la cual se expide el Código de Minas y se dictan otras disposiciones". Dicho artículo hace referencia a la participación en la delimitación de las zonas mineras indígenas en las cuales la exploración y explotación del suelo y subsuelo mineros y fue declarado exequible por la Corte Constitucional. 
nación en preservar la seguridad nacional, de la soberanía del Estado y de la conservación del orden público.

\subsubsection{Derecho a los recursos naturales ${ }^{61}$}

Unido al derecho territorial, está el derecho a los recursos naturales. Para el Convenio 169 de la oIT, los pueblos indígenas tienen derecho a los recursos naturales existentes en sus tierras, lo que implica que participan en su utilización, administración y conservación.

E1 artículo 15 del mencionado convenio consagra que en caso de que pertenezcan al Estado los minerales o los recursos del subsuelo, o de que el mismo tenga derechos sobre otros recursos existentes en las tierras de los pueblos indígenas, los gobiernos deberán establecer o mantener procedimientos con miras a consultar a estas colectividades, a fin de determinar si se perjudicarían sus intereses y en qué medida, antes de emprender o autorizar cualquier programa de prospección o explotación de los recursos existentes en sus tierras.

Igualmente, los pueblos indígenas deberán participar, siempre que sea posible, de los beneficios que reporten tales actividades y percibir una indemnización equitativa por cualquier daño que puedan sufrir como resultado de su ejecución. Sobre este particular, según la guía de aplicación del Convenio 169 de la oit, la frase "siempre que sea posible" quiere decir que los gobiernos mantienen el derecho a decidir si los pueblos indígenas se benefician o no de la explotación de los recursos naturales ubicados en sus tierras. Sin embargo, se exige que haya consultas y participación y que se adopten medidas efectivas que permitan a los pueblos tomar parte activa en las decisiones que los afectan. Además, se exige que se efectúe una evaluación del impacto social, espiritual, cultural y ambiental de cualquier actividad desarrollada, de manera que se garantice que las comunidades indígenas tengan la oportunidad de participar en las decisiones con respecto a la disyuntiva de si deben hacerse o no las obras.

Sobre este particular, la Constitución Política de Colombia señala que los bienes de uso público, las tierras comunales de grupos étnicos, las tierras de resguardo y el patrimonio arqueológico de la nación son inalienables, im-

\footnotetext{
${ }^{61}$ En relación con el derecho a los recursos naturales se sugiere ver la siguiente jurisprudencia de la Corte Constitucional: su-039 de 1997, T-652 de 1998, C-169 de 2001, C-892 de 2001, C-418 de 2002, C-891 de 2002, C-620 de 2003, T-955 de 2003, T-880 de 2006, T-769 de 2009, T-1045A de 2010 y C-366 de 2011.
} 
prescriptibles e inembargables. De igual forma, el parágrafo del artículo 330 dispone que la explotación de los recursos naturales en los territorios indígenas debe hacerse sin desmedro de la integridad cultural, social y económica de las comunidades y que en las decisiones que se adopten en relación con dicha explotación el gobierno propiciará la participación de los representantes de las respectivas comunidades y pueblos indígenas.

Es importante resaltar que el reconocimiento del derecho a la propiedad colectiva de los resguardos (CP, art. 329), en favor de las comunidades y pueblos indígenas, comprende la propiedad colectiva de estas sobre los recursos naturales no renovables existentes en su territorio. Lejos de usurpar recursos de la nación, el acto de disposición de bienes baldíos para la constitución de resguardos indígenas es compatible con el papel fundamental que estos grupos humanos desempeñan en la preservación del medio ambiente. Además, la prevalencia de la integridad cultural, social y económica de estas comunidades, sobre la explotación de los recursos naturales en sus territorios - la que sólo es posible si media la autorización previa del Estado (CP, art. 80) y de la comunidad indígena ( $\mathrm{CP}$, art. 330)—, se erige en límite constitucional explícito a la actividad económica de la explotación forestal (ccc, T-652/98).

\subsection{Jurisprudencia sobre el derecho a los recursos naturales}

El derecho a los recursos naturales ha sido abordado por la Corte Constitucional en jurisprudencia diversa. Para esta corporación (T-769/0962), la explotación de los recursos naturales en los territorios indígenas hace necesario armonizar dos intereses contrapuestos: por una parte, la necesidad de planificar el manejo y aprovechamiento de los recursos naturales en los referidos

62 Acción de tutela presentada por los miembros de la comunidad Bachidubi, resguardo río $\mathrm{Mu}$ rindó, contra los ministerios del Interior y de Justicia; de Ambiente, Vivienda y Desarrollo Territorial; de Defensa; de Protección Social; y de Minas y Energía, por considerar que un proyecto vulneraba sus derechos "a la vida, a la seguridad personal, a la consulta previa, a la existencia, a la integridad cultural y social, a la identidad cultural, a la autonomía de las comunidades culturales, a la protección de la riqueza de la Nación y al debido proceso", por los hechos que a continuación son resumidos. La Corte Constitucional concede la protección de los derechos al debido proceso; a la consulta previa con las comunidades autóctonas y a la existencia, autonomía, integridad e identidad cultural y social de tales comunidades, al igual que a las riquezas naturales de la nación. Además ordena a todas las autoridades accionadas que en el ámbito de sus respectivas funciones, y de inmediato, hagan suspender las actividades de exploración y explotación que se estén adelantando o se vayan a adelantar, en desarrollo del contrato de concesión denominado Mandé Norte, para la exploración y explotación de cobre, oro, molibdeno y otros minerales, en los departamentos de Antioquia y Chocó. Efectúa otras órdenes específicas a diversas instituciones. 
territorios, para garantizar su desarrollo sostenible, su conservación, restauración o sustitución (cP, art. 80) y, por otra, la de asegurar la protección de la integridad étnica, cultural, social y económica de las comunidades y pueblos indígenas que ocupan dichos territorios, es decir, de los elementos básicos que constituyen su cohesión como grupo social y que, por tanto, son el sustrato para su subsistencia. Lo anterior significa que debe buscarse un equilibrio o balance entre el desarrollo económico del país que exige la explotación de dichos recursos y la preservación de la integridad cultural, que es condición para la subsistencia del grupo humano indígena.

A juicio de la Corte Constitucional, la participación de las comunidades y pueblos indígenas en las decisiones que pueden afectarlas en relación con la explotación de los recursos naturales, ofrece como particularidad el hecho de que, a través del mecanismo de la consulta previa, esta adquiere la connotación de derecho fundamental (ccc, su-039/9763 y C-891/0264). Para el alto tribunal, la explotación de recursos naturales en territorios indígenas plantea un problema constitucional que involucra la integridad étnica, cultural, social y económica de las comunidades que sobre ellos se asientan.

Sobre este tema en particular, la jurisprudencia constitucional ha señalado que la participación indígena encuentra un sustento que desborda la esfera netamente política del concepto, en la medida en que hace parte de una cosmogonía según la cual dicho valor está relacionado con el respeto a los seres vivos, con no tomar nunca más de lo que se necesita y devolver siempre a la tierra cuando se toma algo de ella. En síntesis, de la concepción holística de territorio que ostentan los pueblos indígenas se puede concluir que la explotación de recursos naturales yacentes en territorios ancestrales hace parte de su esfera vital y de su forma de relacionarse directamente con la naturaleza, así como de su legado cultural y socio-económico. De esta manera, el principio participativo consagrado en el artículo $2^{\circ}$ de la Constitución Política adquiere matices más intensos en relación con estas comunidades (ccc, C-891/02).

${ }^{63}$ Acción de tutela presentada por el defensor del pueblo, en representación de varias personas integrantes del grupo étnico indígena U'wa en el caso del desarrollo del proyecto conocido como "Exploración Sísmica Bloque Samoré". La Corte Constitucional tutela los derechos a la participación, a la integridad étnica, cultural, social y económica y al debido proceso de la comunidad U'wa.

${ }^{64}$ Demanda de inconstitucionalidad contra varios artículos de la Ley 685 de 2001 - Código de Minas -. La Corte Constitucional declaró la exequibilidad de la mayoría de ellos. 
Como se ha venido señalando, la Corte Constitucional resalta (ccc, C-891/02 y C-620/0365) el derecho a la participación de las comunidades y pueblos indígenas en la adopción de las decisiones que les conciernen, especialmente las relativas a la explotación de los recursos naturales ubicados en sus territorios, como expresamente lo prescribe el parágrafo del artículo 330 de la Constitución. Este derecho, por la particular influencia que el ambiente tiene en la definición de los rasgos de las culturas indígenas, ha sido estimado además por la jurisprudencia constitucional, como un derecho fundamental. Ahora bien, en el caso de explotación de recursos naturales, el alto tribunal ha identificado que la participación de las comunidades tradicionales en los proyectos que los afectan se explica, del mismo modo, por los potenciales efectos nocivos que tienen los proyectos a gran escala para los intereses de los pueblos. Estos efectos, a su vez, deben mirarse no sólo desde la perspectiva del compromiso específico con territorios "propios" de los pueblos étnicos, sino respecto a toda actividad de desarrollo que llegase a afectar directamente sus intereses ${ }^{66}$.

En este mismo sentido, en la actividad de exploración y explotación minera en Colombia, convergen diversos factores de riesgo para la vigencia de los derechos constitucionales de las comunidades étnicas. Aunque se trata de una actividad legal que se encuentra sometida a fuertes regulaciones, la experiencia histórica ha demostrado que los proyectos mineros son especialmente sensibles a acciones como la incursión de grupos armados ilegales, el desplazamiento forzado de las comunidades que habitan las zonas afectadas y la contaminación del ambiente. Estos riesgos, que lastimosamente son connaturales a la actividad minera, exigen un especial deber estatal de garantía de la consulta previa a las comunidades y pueblos indígenas. La participación en estos casos, respecto a las medidas relacionadas con el aprovechamiento

${ }^{65}$ Demanda de inconstitucionalidad contra la Ley 773 de 2002 y contra su artículo primero (parcial). Norma por la cual se dictan normas relativas a la administración, fabricación, transformación, explotación y comercialización de las sales que se producen en las salinas marítimas ubicadas en el municipio de Manaure, Guajira y Salinas de Zipaquirá y se dictan otras disposiciones. La Corte Constitucional encontró la norma demandada ajustada a la constitución política.

${ }^{66}$ Con el fin de profundizar sobre este tema se sugiere ver Muñoz Onofre (2014). 
de recursos mineros ubicados en sus territorios, debe ser compatible con las condiciones propias de su identidad diferenciada (ccc, C-366/1167).

\subsubsection{Derecho propio o consuetudinario ${ }^{68}$}

El Convenio 169 de la oit señala que los pueblos indígenas tienen el derecho de conservar sus costumbres e instituciones propias y a gozar de los derechos que en general han sido reconocidos a toda la población, lo cual significa que al aplicar la legislación interna deberán tomarse en consideración sus costumbres o su derecho consuetudinario. Ellos poseen sus propias formas de justicia y para poder aplicar sus prácticas y costumbres tradicionales cuentan con estructuras institucionales como los órganos o consejos judiciales y administrativos, los cuales poseen normas y reglamentos que aseguran el cumplimiento de las leyes consuetudinarias (огт 2009, 81). En este sentido, el Convenio 169 establece que al aplicar la legislación nacional a estas comunidades indígenas deberán tenerse debidamente en consideración sus costumbres o su derecho consuetudinario.

En Colombia, las autoridades de los pueblos indígenas (según el artículo 246 de la Constitución Política) pueden ejercer funciones jurisdiccionales en su ámbito territorial de conformidad con sus propias normas y procedimientos, siempre que estas no sean contrarias a la Carta Política y a las leyes de la república. Lo anterior quiere decir que los pueblos indígenas y sus comunidades cuentan con la facultad de administrar justicia en sus territorios.

Sobre ese tema, la DNUDPI, en su artículo 34, establece que esos pueblos y comunidades tienen derecho a promover, desarrollar y mantener sus estructuras institucionales y sus propias costumbres, espiritualidad, tradiciones,

\footnotetext{
${ }^{67}$ En ejercicio de la acción pública consagrada en el artículo 241 de la constitución, instauran demanda de inconstitucionalidad en contra de la Ley 1382 de 2010, "Por la cual se modifica la Ley 685 de 2001 Código de Minas”, en su integridad. La Corte Constitucional declara la inexequibilidad diferida de dicha norma por carecer del proceso de consulta previa.

${ }^{68}$ En relación con el derecho propio se sugiere ver entre otras, la siguiente jurisprudencia de la Corte Constitucional: T-254 de 1994, C-037 de 1996, C-139 de 1996, T-349 de 1996, T-344 de 1998, T-667A de 1998, su-510 de 1998, T-266 de 1999, T-934 de 1999, T-606 de 2001, T-1127 de 2001, T-048 de 2002, C-370 de 2002,T-239 de 2002,T-728 de 2002, C-127 de 2003, T-552 de 2003,T-811 de 2004, T-1238 de 2004, T-1070 de 2005, T-1294 de 2005, T-009 de 2007, T-549 de 2007, T-945 de 2007, T-996 de 2007, C-713 de 2008, T-1026 de 2008, T-1253 de 2008, T-617 de 2010, T-454 de 2013, T-659/13,T-921/13, C-463/14.
} 
procedimientos, prácticas y, cuando existan, costumbres o sistemas jurídicos, de conformidad con las normas internacionales de derechos humanos.

Para la experta Sánchez Botero, la jurisdicción indígena es desarrollada de acuerdo con las concepciones culturales de lo que es el ser humano y el tipo de relaciones que debe tener con sus semejantes y con el medio que lo rodea. Los diferentes sistemas de justicia indígena reflejan la organización social y regulan las conductas mediante las normas consuetudinarias y otros mecanismos de control. Los distintos pueblos conjuran las desviaciones conductuales y ponen al día sus conflictos, a través de principios y reglas prácticas que son puestas en vigor por medio de sanciones, las cuales son concebidas en comunión con las fuerzas de la naturaleza y trasmitidas esencialmente de manera oral (Sánchez Botero 2001, 62, 159, 199).

En este sentido, se deben respetar los métodos tradicionales a los que recurren los pueblos indígenas para la represión de las infracciones cometidas por sus miembros. Sin embargo, es importante tener en cuenta que las sanciones que se impongan a los miembros de estos pueblos deberán tener en cuenta sus características económicas, sociales y culturales; dar preferencia a tipos de sanción distintos del encarcelamiento y tomar medidas para garantizar que los mismos puedan comprender y hacerse comprender en procedimientos legales, facilitándoles, si fuere necesario, intérpretes u otros medios eficaces para tal fin. ${ }^{69}$

En su análisis sobre los elementos centrales de la jurisdicción indígena, la Corte Constitucional (C-139/96 70 ) estableció que cualquier tipo de decisión en los pueblos indígenas se toma y debe fundamentarse en sus autoridades, es decir, con las instituciones tradicionales de cada pueblo y por medio de sus propias autoridades o las organizaciones que las representan, las cuales son las competentes de acuerdo con las leyes de origen, el derecho mayor o el de-

\footnotetext{
${ }^{69}$ Para profundizar, véase también: Sánchez Botero y Jaramillo Sierra (2000) C.S.J. y onic (2006) y Ariza Santamaría (2010a).

70 Demanda de inconstitucionalidad contra los artículos 1,5 y 40 de la Ley 89 de 1890. La Corte Constitucional considera inexequible la norma demandada que señala a los indígenas como salvajes y por tratarlos como incapaces relativos, tratamiento que deriva, sin duda, de considerar que quienes no son partícipes del mundo de valores prevaleciente en el país y que pudiera comprenderse bajo el rubro genérico de "cultura occidental" son personas menguadas urgidas de tutela paternalista. Tal actitud, ciega para la comprensión de otras formas de vida y otras cosmovisiones, es incompatible con la filosofia pluralista que informa la normatividad básica de 1991, armónica a la vez con el reconocimiento de la dignidad humana como supuesto incontrovertible.
} 
recho propio, para administrar justicia al interior de los pueblos indígenas de Colombia. Ellas pueden establecer las normas y procedimientos propios de acuerdo con sus usos y costumbres, para de esta forma ejercer la jurisdicción especial indígena de manera autónoma. La posibilidad que existan autoridades judiciales propias y su potestad para establecer las normas y procedimientos conforman lo que se conoce como el núcleo de autonomía otorgada a estas comunidades que se extiende no sólo al ámbito jurisdiccional, sino también al legislativo.

\subsection{Fuero indígena}

El fuero indígena es el derecho de los miembros de una comunidad indígena a ser juzgados por sus propias autoridades, de acuerdo con sus normas y procedimientos. Implica que el juicio lo hace un juez diferente al que ordinariamente tiene la competencia para el efecto. Gozan de ese derecho por el hecho de pertenecer a la comunidad o al pueblo indígena.

Dicho reconocimiento se impone dada la imposibilidad de traducción fiel de las normas de los sistemas indígenas al sistema jurídico nacional y viceversa. Esa circunstancia obedece en buena medida a la diversidad de sistemas de resolución de conflictos, derivada del alto número de comunidades y pueblos indígenas. También, a que los parámetros de convivencia de dichas comunidades tienen concepciones sui generis, que por lo general se refieren al "ser" más que al "deber ser", apoyadas en una visión que integra el ser humano y la naturaleza y en un sistema de creencias mágico-religiosas (ccc, T-728/0271).

De acuerdo con lo anterior, la Corte Constitucional ha establecido que los elementos que comprende el fuero indígena son:

a) El personal, con el que se pretende señalar que el individuo debe juzgarse de acuerdo con las normas y las autoridades de su propia comunidad.

\footnotetext{
${ }^{71}$ Acciones de tutela instauradas contra la Corte Suprema de Justicia —Sala de Casación Penal, y por Omaira Pancho Sancha contra la Fiscalía 23 Seccional y el Juzgado Único Penal del Circuito de La Plata, Huila, solicitando que se protejan los derechos de un indígena al debido proceso, igualdad, acceso a la administración de justicia, juez natural y autonomía e integridad cultural, los cuales estima vulnerados por la jurisdicción penal ordinaria. La Corte Constitucional estudia el caso y decide tutelar los derechos fundamentales al debido proceso y a la autonomía e integridad cultural del solicitante y de su comunidad.
} 
b) El territorio, que permite que cada comunidad pueda juzgar las conductas que tengan ocurrencia en su territorio, de acuerdo con sus propias normas.

c) El objeto, referido a la calidad del sujeto o del objeto sobre los que recae la conducta delictiva.

Las autoridades indígenas son el juez natural para conocer los delitos cometidos por miembros de su comunidad, siempre y cuando se atiendan los requisitos establecidos para el reconocimiento del fuero indígena (ccc, T-811/0472).

Recientemente, la Corte Constitucional (Sentencia T-454/1373) hizo referencia al tema y estableció que el derecho de los miembros de los pueblos indígenas a gozar de un fuero es correlativo al derecho colectivo de la comunidad a juzgar a sus miembros. Así, la noción de fuero indígena comporta dos elementos: (i) uno personal, el cual implica que los miembros de la comunidad sean juzgados de acuerdo a sus usos y costumbres; y (ii) otro geográfico, que justifica el juzgamiento de la respectiva comunidad por los hechos que sucedan en su territorio, de acuerdo a sus propias normas. Reitera el tribunal constitucional que estos criterios son los que determinan el ámbito de la jurisdicción indígena. Sin embargo, para que proceda la aplicación de tal jurisdicción no es suficiente la constatación de estos dos criterios, puesto que también se requiere que existan unas autoridades tradicionales que puedan ejercer las funciones jurisdiccionales, y la definición de un ámbito territorial en el cual ejerzan su autoridad, además de la existencia de usos y prácticas

${ }^{72}$ Acción de tutela instaurada por un indígena contra la asamblea general de cabildo y el cabildo indígena de Quizgó, acusado de causar heridas con arma cortopunzante a un comunero, que le ocasionaron la muerte de manera casi inmediata. Analiza la Corte Constitucional el caso, haciendo precisiones sobre el tema de jurisdicción especial indígena y protegiendo los derechos correspondientes.

${ }^{73}$ Acción de tutela instaurada por una mujer indígena, quien solicita la protección de sus derechos a la vida, a la salud e integridad personal, al debido proceso y a la igualdad ante una sanción que le había sido impuesta por la autoridad indígena. En este caso, la Corte Constitucional insta al gobernador del cabildo indígena de Ipiales, para que mediante los usos y costumbre propios de esa comunidad invite a la señora y a los miembros de su familia a solucionar pacíficamente los conflictos que se vienen suscitando, guardando el respeto debido que debe existir entre ellos y cumpliendo los compromisos de no agresión física o verbal adquiridos. De igual forma, ordena a la señora acatar las recomendaciones y los compromisos asumidos ante el cabildo, abstenerse de agredir física y verbalmente a los integrantes de su familia, y procurar una sana convivencia. 
tradicionales sobre la materia, y la condición de que tales usos y prácticas no contraríen la Constitución ni la ley.

\subsection{Jurisprudencia sobre el derecho propio}

Para la Corte Constitucional (T-606/0174), en la jurisdicción especial indígena se reconoce a las autoridades indígenas la facultad de administrar justicia según las normas consuetudinarias de competencia y las especiales que regulen la vida y actividad de los indígenas. Para que proceda la jurisdicción indígena sería necesario acreditar que: nos encontramos frente a una comunidad o pueblo indígena; esta cuenta con autoridades tradicionales; las mismas ejercen su autoridad en un ámbito territorial determinado; existen una serie de usos y prácticas tradicionales, tanto en lo sustantivo como en lo procedimental: y, la condición de que tales usos y prácticas no resultan contrarias a la Constitución o a la ley.

Considera la Corte Constitucional (T-552/0375) que la jurisdicción indígena comporta: a) un elemento humano, que consiste en la existencia de un grupo diferenciable por su origen étnico y por la persistencia diferenciada de su identidad cultural; b) un elemento orgánico, esto es, la existencia de autoridades tradicionales que ejerzan una función de control social en sus comunidades; c) un elemento normativo, es decir, que la respectiva comunidad se rija por un sistema jurídico propio conformado a partir de las prácticas y usos tradicionales, tanto en materia sustantiva como procedimental; d) un ámbito geográfico, en cuanto la norma que establece la jurisdicción indígena remite al territorio, el cual, según el artículo 329 de la Constitución, deberá conformarse con sujeción

\footnotetext{
${ }^{74}$ Acción de tutela instaurada por el gobernador del resguardo indígena de Cañamomo y Lomaprieta situado en Riosucio y Supía (Caldas), contra el Juzgado Primero Promiscuo Municipal de Supía por haber incurrido en vía de hecho al usurpar jurisdicción y decidir un asunto que le correspondía al cabildo de dicho resguardo. Alega que en virtud de la autonomía concedida por la Constitución a los pueblos indígenas, tratándose de controversias jurídicas referentes a las tierras que hacen parte de los resguardos, la jurisdicción ordinaria no es la llamada a definir. La Corte Constitucional concede la tutela, declara la nulidad de todo lo actuado por el juzgado y ordena que se envíe el expediente a la jurisdicción indígena representada en el cabildo del resguardo indígena de Cañamomo y Lomaprieta.

75 Acción de tutela instaurada por un indígena contra el Consejo Superior de la Judicatura en un caso de jurisdicción especial. La Corte Constitucional tutela los derechos fundamentales a la diversidad, la autonomía y el debido proceso de la comunidad indígena de Caquiona y del integrante de la misma y ordena al Consejo Superior de la Judicatura, Sala Jurisdiccional Disciplinaria que se resuelva el conflicto de competencias que plantea este caso, conforme a los criterios étnicos y de respeto de los derechos de estos pueblos.
} 
a la ley y delimitarse por el gobierno con la participación de las comunidades; e) un factor de congruencia, en la medida en que el orden jurídico tradicional de estas comunidades no puede resultar contrario a la Constitución ni a la ley.

Así, las autoridades indígenas pueden reclamar el ejercicio de la jurisdicción, en la medida en que cuentan con la necesaria organización, con el reconocimiento comunitario y con la facultad de control social. Sin embargo, la progresiva asunción de responsabilidad o de opciones de autonomía implican también la adquisición de deberes y responsabilidades conforme a los cuales el carácter potestativo de la jurisdicción deja de ser una opción abierta a la comunidad para convertirse en un elemento objetivo vinculado a la existencia de la organización.

Por ejemplo, una vez asumida esa función jurisdiccional, no pueden las autoridades tradicionales ejercerla de manera selectiva (en unos casos sí y en otros, no) y surge de manera plena el fuero para los integrantes de la comunidad. De conformidad con eso, estas personas tienen el derecho a ser juzgadas por su propias autoridades, las que, a su vez, tienen el deber de hacerlo (cCC, T-552/03).

Finalmente, es importante mencionar que la implementación eficaz de los derechos de los pueblos indígenas reconocidos internacionalmente -incluso los derechos sobre las tierras y los recursos, y los derechos culturales, sociales y económicos- exige el reconocimiento y la aceptación de las costumbres, el derecho consuetudinario y los sistemas jurídicos de los pueblos indígenas, en especial en lo que respecta a los derechos colectivos, que son de fundamental importancia para estos (отт 2009, 81).

\subsection{Limites al derecho propio}

Para la Corte Constitucional (T-523/9776), tanto las autoridades indígenas como las normas que constituyen el derecho propio cuentan con unos límites

\footnotetext{
${ }^{76}$ Un indígena páez interpuso acción de tutela contra el gobernador del cabildo indígena de Jambaló y contra el presidente de la Asociación de Cabildos de la Zona Norte del Departamento del Cauca, por violación de sus derechos a la vida, a la igualdad y al debido proceso. Solicitó a través de este mecanismo judicial que el informe final de la investigación realizada por las autoridades indígenas del norte del Cauca, en relación con una muerte, no fuera presentado a la comunidad páez. La Corte Constitucional considera que no asiste razón a los jueces de tutela por no presentarse violación al debido proceso, pues estas autoridades tuvieron extremo cuidado en cumplir el procedimiento que tradicionalmente se utiliza en la comunidad. Además, se le permitió ejercer su defensa personalmente durante las asambleas realizadas y se le brindó la posibilidad de ser defendido por un miembro de la comunidad, siempre y cuando
} 
mínimos, que deben cumplirse en materia de derechos humanos. En primer lugar, está el derecho a la vida, considerado como el bien más preciado del ser humano. En segundo lugar, la prohibición de la esclavitud y la tortura y, en tercer lugar, por expresa exigencia constitucional, la legalidad en el procedimiento, en los delitos y en las penas. Esto quiere decir que las normas y los procedimientos deben atender a la especificidad de la organización social y política de la comunidad o pueblo indígena, así como a los caracteres de su ordenamiento jurídico. Cuando se plantea que las funciones jurisdiccionales reconocidas a las autoridades indígenas deben ejercerse de acuerdo con sus propias normas y procedimientos, es importante señalar que estas no deben ser contrarias a la Constitución ni a la ley. La corte ha interpretado dicha restricción en el sentido de que no cualquier norma legal o constitucional puede oponerse al ejercicio de la autonomía de las comunidades indígenas, so pena de vaciar de competencia la cláusula autonómica (Botero Marino 2003, 53).

Por otro lado, es necesario prever que cualquier situación en la cual se requiera de la intervención de dichas autoridades indígenas debe tener en cuenta las normas y el derecho propio, además de la perspectiva de los derechos humanos y del derecho constitucional. En este punto, según el tribunal constitucional (T-349/96), el principio de maximización de la autonomía adquiere gran relevancia por tratarse de relaciones puramente internas, de cuya regulación depende en gran parte la subsistencia de la identidad cultural y la cohesión del grupo. Los límites a las formas en las que se ejerce este control interno deben ser, entonces, los mínimos aceptables, por lo que sólo pueden estar referidos a lo que verdaderamente resulta intolerable por atentar contra los bienes más preciados del hombre.

Por último, es importante resaltar el cuestionamiento a la regla que señala que a mayor conservación de los usos y las costumbres, mayor autonomía, en razón a las dinámicas culturales y a los procesos de re-etnicidad y re-indigenización. Sobre el particular, Lopera Mesa y Hoyos Ceballos $(2008,158)$ aseguran que "este modo de identificar las normas que integran el derecho

conociera la lengua y las costumbres, como así lo contempla el procedimiento utilizado tradicionalmente en Jambaló. Para este alto tribunal, las sanciones, por su parte, tampoco sobrepasaron los límites impuestos al ejercicio de funciones jurisdiccionales por parte de las autoridades indígenas, en primer lugar, porque de acuerdo con las faltas cometidas, es decir,la calumnia y el desconocimiento de la autoridad del cabildo, tanto la pena del fuete como la de destierro era previsible para el actor. En segundo lugar, porque ninguna de ellas desconoció el derecho a la vida, la prohibición de esclavitud o la prohibición de la tortura. 
propio de una comunidad tiene un sentido claramente conservador, al hacer depender la autonomía reconocida a las comunidades del grado en que sus normas perpetúen la tradición". Igualmente, al postular esta regla, la corte parece entender que, cuando en una comunidad desaparece la normatividad ancestral, sólo queda el vacío, y que en tales circunstancias es legítimo colmarlo con el derecho estatal. Tal comprensión es criticable por cuanto, admitido el carácter dinámico de las culturas, queda sin sustento la pretensión de fijar el derecho indígena y el cierre a la creación normativa actual que resulta de entender como derecho propio sólo al derecho ancestral de una comunidad. Por otra parte, ella limita considerablemente el espacio para la autonomía jurisdiccional de las comunidades que, en el marco de procesos de re-indigenización, se han dado a la tarea de reconstruir su juridicidad perdida.

\subsection{Reivindicación de la autonomía jurisdiccional}

Para finalizar esta parte de la autonomía y el derecho propio, es importante resaltar que recientemente la Corte Constitucional (Sentencia C-463/1477) reivindicó la autonomía jurisdiccional de los pueblos indígenas para resolver sus conflictos a través de sus autoridades propias y según sus procedimientos. En este caso concreto, el alto tribunal consideró inexequible el artículo 11 de la Ley 89 de 1890, que establecía que las controversias entre indígenas de una misma comunidad, o de estos contra los cabildos, por razón de uso de los resguardos o de los límites de las porciones que gocen, serán resueltas por el alcalde del distrito municipal a que pertenezcan, quien los oirá en juicio de policía en la forma que lo indiquen las disposiciones de la materia. Sus resoluciones serán apelables ante los prefectos de las provincias, y las de estos ante los gobernadores de departamento.

En su análisis la Corte Constitucional se enmarcó en el desarrollo normativo y jurisprudencial de la diversidad étnica y cultural. Señaló que la consagración en el artículo 246 de la Constitución Política de la autonomía jurisdiccional que comporta la potestad de crear normas y procedimientos para resolver los conflictos de las comunidades indígenas, siempre que no se

\footnotetext{
${ }_{77}$ Demanda de inconstitucionalidad contra el artículo 11 de la Ley 89 de 1890, sobre las controversias entre indígenas de una misma comunidad, o de estos contra los cabildos, por razón de uso de los resguardos o de los límites de las porciones de que gocen, las cuales serán resueltas por el alcalde del distrito municipal a que pertenezcan. Dicha norma fue declarada inexequible por la Corte Constitucional.
} 
opongan a la Constitución y la ley, ha originado conflictos normativos y colisiones de principios, algunos dilucidados por la corte por la vía de revisión de fallos de tutela y otros, en sede de control abstracto de constitucionalidad.

En este caso concreto, el estudio del tribunal constitucional se concentró en el punto de los límites a la autonomía de los pueblos indígenas, los cuales, según lo ha precisado la jurisprudencia constitucional, sólo son admisibles cuando (i) sean necesarios para salvaguardar un interés de mayor jerarquía, en la circunstancias del caso concreto; y (ii) sean los menos gravosos, frente a cualquier medida alternativa, para el ejercicio de esa autonomía. La corte ha señalado que la evaluación de estos elementos debe llevarse a cabo teniendo en cuenta las particularidades de cada comunidad. Así mismo, la jurisprudencia constitucional ha determinado que la autonomía de los pueblos indígenas es más amplia cuando se trata de conflictos que involucran únicamente a miembros de una comunidad que cuando afectan a miembros de culturas diferentes, por cuanto deben armonizarse principios esenciales de cada una de las culturas en tensión.

En una primera aproximación al sentido y alcance del artículo 246 de la Carta Política, el tribunal constitucional consideró que la autonomía jurisdiccional resultaba prevalente frente a normas legales dispositivas, pero debía ceder en caso de incompatibilidad con cualquier norma constitucional o legal imperativa. Posteriormente, estimó que limitar la autonomía indígena frente a cualquier norma legal o constitucional resultaría inconsistente con la decisión del constituyente de elevar la autonomía jurisdiccional indígena a derecho fundamental, toda vez que (i) no puede defenderse la jerarquía y fuerza normativa de la Constitución, si sus normas son desplazadas por todo mandato legal imperativo; y (ii) no existe un orden jerárquico prestablecido entre las cláusulas superiores de la Carta Política; tampoco puede preverse, en abstracto, que el artículo 246 superior pueda ser desplazado por cualquier otra cláusula superior.

En la mencionada sentencia, se decidió unificar algunas de las subreglas establecidas sobre la materia por las salas de revisión, según las cuales la efectividad de los derechos de los pueblos indígenas determina que los límites susceptibles de ser impuestos a la autonomía normativa y jurisdiccional de tales comunidades sólo sean aquellos que se encuentren referidos a "lo que verdaderamente resulta intolerable por atentar contra los bienes más preciados del hombre", esto es, el derecho a la vida, la prohibición de la tortura, la 
esclavitud, la legalidad del procedimiento, de los delitos y las penas, derechos sobre los cuales existe verdadero consenso intercultural; además, pertenecen al grupo de derechos intangibles reconocidos por todos los tratados internacionales de derechos humanos y no pueden ser suspendidos ni siquiera en situaciones de conflicto armado. Específicamente, en relación con el derecho a la legalidad del procedimiento y de los delitos y las penas, la jurisprudencia ha precisado que el artículo 246 de la Constitución hace expresa referencia a que el juzgamiento se hará conforme a las "normas y procedimientos" de la comunidad indígena, lo cual supone la preexistencia de los mismos respecto al juzgamiento de las conductas.

Por otra parte, la corte señaló como elementos estructurales de la jurisdicción especial indígena: (i) la facultad de las comunidades de establecer autoridades judiciales propias; (ii) la potestad de conservar o proferir normas y procedimientos propios; (iii) la sujeción de los elementos anteriores a la Constitución y a la ley; (iv) la competencia del legislador para establecer la forma de coordinación interjurisdiccional, sin que, en todo caso, (v) el ejercicio de la jurisdicción indígena esté condicionado a la expedición de la ley mencionada. De igual modo, resaltó la doble dimensión del fuero indígena, en tanto derecho de las personas que reclaman una identidad étnica indígena a ser juzgadas de acuerdo con los sistemas de regulación de las propias comunidades y garantía institucional de la autonomía indígena. Como factores constitutivos del fuero indígena deben tenerse en cuenta tanto el personal como el territorial, de modo que si la conducta objeto de investigación (o el conflicto, en términos más amplios) tuvo lugar dentro del territorio de una comunidad indígena, debe ser conocida por las autoridades de esa comunidad.

\subsubsection{Derecho a la consulta previa}

Colombia, como un país democrático y participativo, encuentra en la consulta previa su máxima expresión como un espacio de articulación étnica e intercultural. Según el artículo 6 del Convenio 169 de la oIT, el Estado colombiano tiene la obligación de consultar a los pueblos indígenas y tribales mediante procedimientos apropiados y, en particular, a través de sus instituciones representativas, cada vez que se prevean medidas legislativas o administrativas susceptibles de afectarles directamente. Dichas consultas deberán efectuarse de buena fe y de una manera apropiada a las circunstancias, con la finalidad de llegar a un acuerdo o lograr el consentimiento 
La consulta previa se fundamenta, según el artículo 7 del Convenio 169 de la oit, en el derecho que tienen los pueblos de decidir sus propias prioridades en lo que concierne al proceso de desarrollo, en la medida que este afecte sus vidas, creencias, instituciones, bienestar espiritual y las tierras que ocupan o utilizan de alguna manera. Adicionalmente, tiene que ver con la posibilidad de controlar, en la medida de lo posible, su propio desarrollo económico, social y cultural y el derecho de dichos pueblos de participar en la formulación, aplicación y evaluación de los planes y programas de desarrollo tanto nacionales como regionales que puedan afectarles directamente.

Así las cosas, los pueblos indígenas tienen derecho a la participación y a la consulta. La consulta, además de un derecho, es un proceso de carácter público, especial y obligatorio, intercultural e interinstitucional que debe realizarse previamente siempre que se vaya a decidir sobre asuntos de carácter administrativo, legislativo o en proyectos públicos o privados que incidan en sus formas de vida o su integridad étnica, cultural, espiritual, social y económica. Este derecho fundamental es además un mecanismo que le permite a los Estados cumplir con su responsabilidad y deber de proteger la diversidad étnica y cultural, respetar el territorio, la autonomía, la participación y el desarrollo propio, entre, otros derechos (Rodríguez 2014,34).

La Corte Constitucional ha considerado que el derecho a la consulta previa de los pueblos indígenas tiene el carácter de derecho fundamental y, asimismo, que este se fundamenta en el artículo 1 de la Constitución que señala que Colombia es un Estado social de derecho democrático y participativo; en el artículo 2 que establece que uno de los fines del Estado es facilitar la participación de todos en las decisiones que los afectan y en la vida económica, política y administrativa de la nación; en el artículo 7, mediante el cual se reconoce y protege la diversidad étnica y cultural de la nación; y en el artículo 40, según el cual todo ciudadano tiene derecho a participar en la conformación y control del poder político (ccc, T-657/1378).

\footnotetext{
${ }^{78}$ Los miembros directivos del Consejo Comunitario de Mulaló, ubicado en el corregimiento de Mulaló del municipio de Yumbo, Valle, interpusieron acción de tutela contra el Ministerio del Medio Ambiente y Desarrollo Sostenible, Ministerio del Interior, Instituto Nacional de Vías (Invías) y el Consorcio D.I.s. S.A- EDL LTDA, por violación de los derechos al debido proceso administrativo, a la libre determinación, a la consulta previa, a la participación y a la integridad cultural. La Corte Constitucional concede el amparo por el derecho a la consulta previa del Consejo Comunitario de Mulaló y al Ministerio del Interior - Oficina de Consulta Previa, que dentro de los veinte (20) días siguientes inicie la consulta
} 
Es importante resaltar que, según la Corte Constitucional (su-383/03), el Convenio 169 de la oIt y concretamente el derecho de los pueblos indígenas y tribales a la consulta previa conforman junto con la Carta Política el bloque de constitucionalidad. Así las cosas, puede considerarse que este es un derecho de gran trascendencia, el cual no puede suspenderse ni aún en situaciones excepcionales por las siguientes razones:

i) por estar ligados a la existencia de Colombia como Estado social de derecho, en cuanto representa la protección misma de la nacionalidad colombiana - artículos $1^{\circ}$ y $7^{\circ}$ c.P.—,

ii) en razón de que el derecho a la integridad física y moral integra el "núcleo duro" de los derechos humanos, y

iii) dado que la protección contra el etnocidio constituye un mandato imperativo del derecho internacional de los derechos humanos. ${ }^{79}$

Para la Corte Constitucional (su-383/03), el Convenio 169 conforma, junto con la Carta Política, el bloque de constitucionalidad, ${ }^{80}$ no sólo porque el instrumento que la contiene proviene de la Organización Internacional

previa ante el consejo comunitario, en el que se convoque a todas las partes involucradas en el proceso de planeación y ejecución de la carretera Mulaló-Loboguerrero, en lo que respecta a la alternativa 3 ajustada o mejorada. También solicita a la Defensoría del Pueblo y a la Procuraduría General de la Nación apoyar, acompañar y vigilar el pleno cumplimiento de lo determinado en el presente fallo, con el fin de garantizar la efectividad de los derechos aquí protegidos.

${ }^{79}$ Com. DH., observación general número 29, 24 de julio de 2001.

${ }^{80}$ Por bloque de constitucionalidad se puede entender el conjunto de normas que configuran una unidad constitucional que es empleada como parámetro de constitucionalidad de las restantes normas del ordenamiento. Existen dos criterios de identificación de esas normas jurídicas de naturaleza constitucional. El primero, que podríamos denominar formal, según el cual una norma es constitucional por estar en el texto de la Constitución o por existir otra norma que expresamente lo indica. El segundo, denominado criterio material, busca la conformación del bloque de constitucionalidad, no por la autorización de una norma constitucional, sino por el contenido mismo de la norma pretendida como constitucional, partiendo del reconocimiento de que las normas constitucionales no son todas las que figuran en el texto, sino que existen otras que, por su vinculante contexto axiológico (concreción racional de un sentimiento de justicia existente en una comunidad) y su importante función política (legitimación del poder del Estado y medio de expresión de la soberanía jurídica del poder constituyente) demarcan el camino que debe seguir la interpretación y aplicación de las restantes normas del ordenamiento jurídico (Estrada Vélez 2007, 97-98). 
del Trabajo y estipula los derechos laborales de dichos pueblos (CP, artículo 53), sino:

i) en virtud de que la participación de las comunidades indígenas en las decisiones que se adopten respecto de la explotación de recursos naturales en sus territorios, prevista en el artículo 330 de la Carta, no puede ser entendida como la negación del derecho de estos pueblos a ser consultados en otros aspectos inherentes a su subsistencia como comunidades reconocibles - artículo $94 \mathrm{cP}$ -

ii) dado que el convenio en cita es el instrumento de mayor reconocimiento contra las discriminaciones que sufren los pueblos indígenas y tribales,

iii) debido a que el derecho de los pueblos indígenas a ser consultados previamente sobre las decisiones administrativas y legislativas que los afecten directamente, es la medida de acción positiva que la comunidad internacional prohíja y recomienda para combatir los orígenes, las causas, las formas y las manifestaciones contemporáneas del racismo, la discriminación racial, la xenofobia y las formas de intolerancia conexa que afectan a los pueblos indígenas y tribales - Declaración y Programa de Acción de Durban ${ }^{81}$ - y,

iv) debido a que el artículo 27 del Pacto Internacional de Derechos Civiles y Políticos dispone que no se negará a las minorías étnicas el derecho a su identidad.

${ }^{81}$ La Declaración y el Programa de Acción de Durban son el resultado de los estudios y debates presentados antes y durante la Conferencia Mundial contra el Racismo, la Discriminación Racial, la Xenofobia y las Formas Conexas de Intolerancia, llevada a cabo en la ciudad de Durban, Sudáfrica, entre el 31 de agosto y el 8 de septiembre de 2001. El objetivo primordial de estos documentos es dar una serie de lineamientos y recomendaciones a los Estados, a las organizaciones no gubernamentales y al sector privado para emprender una verdadera y frontal lucha contra estos flagelos. 


\subsection{Principio de buenafe}

Para la Corte Constitucional (C-175/0982), el principio de la buena fe que debe primar en la consulta previa significa que: (a) corresponde al Estado colombiano definir las condiciones en las que se desarrollará la consulta, lo cual debe darse con la participación de los pueblos indígenas y, (b) para que la consulta resulte satisfactoria a la luz del ordenamiento constitucional, debe realizarse de manera que sea efectiva y conducente.

En este contexto, otro elemento esencial de la consulta efectiva tiene que ver con el procedimiento culturalmente adecuado, lo cual implica respetar las costumbres y tradiciones de los pueblos indígenas y que la misma sea efectuada mediante relaciones de comunicación, basadas precisamente, en el principio de buena fe. Por ende, para la Corte Constitucional (C-175/09) dicho procedimiento deberá estar dirigido a proteger los derechos fundamentales de las comunidades étnicas, mediante instrumentos de participación que, amén de su disposición y diseño, puedan incidir en la definición del contenido y alcance de la medida legislativa o administrativa que pretenda adoptarse.

Lo anterior implica que la consulta previa no puede concebirse como un mero requisito formal, sino que es un proceso sustantivo de raigambre constitucional, dirigido a que: (i) las comunidades afectadas estén provistas de la información completa, precisa y significativa sobre los proyectos que se pretenden desarrollar en sus territorios o de las medidas legislativas o administrativas del caso; $y$ (ii) se tenga como objetivo principal el logro de un acuerdo con los pueblos indígenas y tribales, quienes podrán discutir el contenido de la política y proponer alternativas a ella.

Además de lo anterior, es importante mencionar que, de conformidad con el principio de la buena fe que informa el proceso consultivo, el tribunal constitucional (C-196/12) ha establecido que la consulta previa debe ser oportuna, es decir que debe hacerse con anterioridad a la adopción de la medida,

\footnotetext{
${ }^{82}$ Demanda de inconstitucionalidad contra la Ley 1152 de 2007, "por la cual se dicta al Estatuto de Desarrollo Rural, se reforma el Instituto Colombiano de Desarrollo Rural, Incoder, y se dictan otras disposiciones". Consideran los actores que esta norma viola los artículos 2, 7, 40 y 330 de la Constitución, al igual que el artículo 6 del Convenio 169 de la oit, que en criterio de los actores hace parte del bloque de constitucionalidad. Ello debido a que la disposición no fue consultada a las comunidades indígenas y afrodescendientes, antes de la radicación del proyecto de ley correspondiente, ni durante el trámite del mismo en el congreso. Dicha norma fue declarada inexequible por la Corte Constitucional.
} 
pues, una vez tomada la misma, la participación de la comunidades étnicas no tendría utilidad alguna, puesto que no podrían influir en el proceso decisorio.

Por otro lado, es indispensable precisar que la consulta previa se efectúa con los pueblos indígenas y demás grupos étnicos. Como se planteó anteriormente, el Convenio 169 habla del término pueblos, que significa no tanto un reconocimiento de independencia frente al Estado, sino el reconocimiento y el respeto de sus especiales características étnicas, culturales y sociales. En este contexto, el ámbito de aplicación y por ende de la realización de la consulta previa tiene que ver en Colombia con cuatro grupos étnicos reconocidos: los pueblos indígenas, la población raizal del archipiélago de San Andrés, Providencia y Santa Catalina; la población negra o afrocolombiana, de la que también hacen parte los palenqueros de San Basilio del municipio de Mahates (Bolívar); y la población Rom o gitana. A continuación se presenta cómo están conformadas estas colectividades en nuestro país:

Tabla 6. Población comunidades étnicas en Colombia

\begin{tabular}{|l|c|}
\hline \multicolumn{1}{|c|}{ Pueblo } & $\begin{array}{c}\text { Población } \\
\text { (número de integrantes) }\end{array}$ \\
\hline Indígenas & 1392623 \\
\hline Negra, mulata y afrocolombiana & 4273722 \\
\hline $\begin{array}{l}\text { Raizales del archipiélago de San Andrés, Providencia y Santa } \\
\text { Catalina }\end{array}$ & 30565 \\
\hline Palenqueros & 7470 \\
\hline Rom & 4858 \\
\hline Total & $\mathbf{5 7 0 9 2 3 8}$ \\
\hline
\end{tabular}

Fuente: Colombia, DNP (2011).

Igualmente es pertinente tener presente que el mencionado Convenio 169 no hace ninguna diferencia en el tratamiento de los pueblos, los cuales tienen los mismos derechos. En consecuencia, los pueblos indígenas y tribales deben ser consultados siempre que se vaya a tomar cualquier decisión que pueda afectarles directamente, es decir, cuando la decisión que se pretenda tomar altere el estatus de la persona o de la comunidad, bien sea porque le impone restricciones o gravámenes, o, por el contrario, les confiere beneficios. Para la Corte Constitucional, "la idea de afectación directa se relaciona con 
la intromisión intolerable en las dinámicas económicas, sociales y culturales abrazadas por las comunidades como propias"(ccc, C-030/08 y T-745/1083).

\subsection{La consulta previa es un derecho fundamental ${ }^{84}$}

Mediante Sentencia su-039/97, el alto tribunal constitucional mencionó los parámetros para la realización de las consultas previas y estableció importantes aportes para la protección y garantía de los derechos de las comunidades. En este fallo el tribunal constitucional deja claro que la consulta previa se constituye en un derecho fundamental cuando manifiesta que:

El derecho fundamental de la comunidad a preservar la integridad se garantiza y efectiviza a través del ejercicio de otro derecho que también tiene el carácter de fundamental, como es el derecho de participación de la comunidad en la adopción de las referidas decisiones. La participación de las comunidades indígenas en las decisiones que pueden afectarlas en relación con la explotación de los recursos naturales ofrece como particularidad el hecho de que la referida participación, a través del mecanismo de la consulta, adquiere la connotación de derecho fundamental, pues se erige en un instrumento que es básico para preservar la integridad étnica, social, económica y cultural de las comunidades de indígenas y para asegurar, por ende, su subsistencia como grupo social.

${ }^{83}$ Acción de tutela instaurada por el representante legal de la Empresa Asociativa de Agricultores del Corregimiento de Pasacaballos y como representante legal del Comité de Veeduría Ciudadana de Pasacaballos 'Ojo Pelao' en contra de la Alcaldía de Cartagena y el Consorcio Vial Isla de Barú. Los accionantes alegan el desconocimiento del derecho a la consulta de las comunidades negras. La Corte Constitucional amparó el derecho a la consulta previa reconocido a favor de las comunidades afrocolombianas y ordena al consorcio vial suspender las actividades iniciadas en desarrollo del proyecto "para la construcción y mejoramiento de la vía transversal de Barú” hasta tanto se lleve a cabo la consulta. Ordena a la Dirección de Asuntos para Comunidades Negras, Afrocolombianas, Raizales y Palenqueras del Ministerio del Interior y de Justicia efectuar la consulta.

${ }^{84}$ En relación con el derecho a la consulta previa se sugiere ver, entre otras, la siguiente jurisprudencia de la Corte Constitucional: su-039 de 1997,T-652 de 1998,T-955 de 2003, su-383 de 2003,T-880 de 2006, T-659 de 2009,T-547 de 2010,T-1045A de 2010,T-129 de 2011,T-693 de 2011. 
Se destaca que, en relación con el carácter fundamental de la consulta previa, han sido reiterados los pronunciamientos y en consecuencia el máximo tribunal de la jurisdicción constitucional (su-383/0385) ha establecido que:

\begin{abstract}
No existe en el ordenamiento un mecanismos distinto a la acción de tutela para que los pueblos indígenas y tribales reclamen ante los jueces la protección inmediata de su derecho a ser consultados, a fin de asegurar su derecho a subsistir en la diferencia, por consiguiente compete al Juez de Tutela emitir las ordenes tendientes a asegurar su supervivencia, en los términos del artículo 86 de la Carta. (ccc, su-383/03)
\end{abstract}

Sobre el tema de la reparación por violación al derecho fundamental de la consulta previa, en su estudio y decisión, la Corte Constitucional (T-693/11) estima que esta se da cuando hay presencia de un daño consumado en lo que se refiere específicamente a la falta de consulta previa. En consecuencia considera necesaria la adopción de medidas para proteger ahora y en lo sucesivo los derechos de las comunidades indígenas.

\title{
2.1.2.6.3. Desarrollo normativo de la consulta previa
}

A nivel del ordenamiento jurídico interno y como complemento al Convenio 169 de la OIT, con relación a la consulta previa encontramos las normas constitucionales colombianas que protegen a los pueblos indígenas y sus derechos,

${ }^{85}$ La Organización de los Pueblos Indígenas de la Amazonía Colombiana —opiac— demanda, mediante esta acción, la protección transitoria de sus derechos fundamentales a la vida, existencia comunitaria, medio ambiente sano, libre desarrollo de la personalidad, debido proceso y derecho a la participación de los pueblos indígenas en las decisiones que los afectan, que estarían siendo quebrantados por los accionados al ordenar y autorizar la fumigación de cultivos ilegales en sus territorios. La Corte Constitucional tutela los derechos fundamentales a la diversidad e integridad étnica y cultural, a la participación y al libre desarrollo de la personalidad de los pueblos indígenas y tribales de la Amazonía colombiana. Además ordena a la Presidencia de la República, a los ministerios del Interior y la Justicia, y de Ambiente, Vivienda y Desarrollo Territorial, al Consejo Nacional de Estupefacientes y a cada uno de sus integrantes, a la Dirección Nacional de Estupefacientes y a la Policía Nacional consultar de manera efectiva y eficiente a los pueblos sobre las decisiones atinentes al Programa de Erradicación de Cultivos Ilícitos que las entidades mencionadas adelantan en sus territorios, en los aspectos que a cada una de dichas entidades compete, "con la finalidad de llegar a un acuerdo o lograr el consentimiento acerca de las medidas propuestas", con plena observancia de los principios y reglas contenidos en el Convenio 169 de la ort, aprobado por la Ley 21 de 1991. 
entre las cuales está el de participar en la toma de decisiones. En este sentido, la Carta Magna considera que uno de los fines del Estado es facilitar la participación de todos en las decisiones que los afecten y en la vida económica, política, administrativa y cultural de la nación. La Constitución Política sobre este tema en el parágrafo del artículo 330 menciona que "La explotación de los recursos naturales en los territorios indígenas se hará sin desmedro de la integridad cultural, social y económica de las comunidades indígenas. En las decisiones que se adopten respecto de dicha explotación, el Gobierno propiciará la participación de los representantes de las respectivas comunidades”.

Por otro lado, el artículo 76 de la Ley 99 de 1993, mediante la cual se crea el Ministerio del Medio Ambiente (hoy Ministerio de Ambiente y Desarrollo Sostenible) y se organiza el Sistema Nacional Ambiental, señala que "La explotación de los recursos naturales deberá hacerse sin desmedro de la integridad cultural, social y económica de las comunidades indígenas y de las negras tradicionales, de acuerdo con la ley 70 de 1993 y el artículo 330 de la Constitución Nacional, y las decisiones sobre la materia se tomarán, previa consulta a los representantes de tales comunidades".

De igual forma, el derecho a la consulta previa cuenta con otras normas que hacen referencia a dicho derecho y que pueden encontrarse en la tabla 7.

Tabla 7. Principales normas sobre consulta previa a pueblos indígenas de Colombia

\begin{tabular}{|l|l|}
\hline \multicolumn{1}{|c|}{ Norma } & \multicolumn{1}{c|}{ Contenido } \\
\hline $\begin{array}{l}\text { Convenio } 169 \text { de la oIT } \\
\text { Ley 21 de } 1991\end{array}$ & $\begin{array}{l}\text { Artículo 6.1. Al aplicar las disposiciones del presente Convenio, los } \\
\text { gobiernos deberán: (a) consultar a los pueblos interesados, mediante } \\
\text { procedimientos apropiados y en particular a través de sus instituciones } \\
\text { representativas, cada vez que se prevean medidas legislativas o adminis- } \\
\text { trativas susceptibles de afectarles directamente. }\end{array}$ \\
\hline Constitución Política de & $\begin{array}{l}\text { Todas las personas tienen derecho a gozar de un ambiente sano. La ley } \\
\text { garantizará la participación de las comunidades en las decisiones que } \\
\text { pueden afectarlo (artículo 79). } \\
\text { La explotación de los recursos naturales en los territorios indígenas se } \\
\text { debe efectuar sin desmedro de la integridad cultural, social y económica } \\
\text { de las comunidades indígenas. En las decisiones que se adopten respecto } \\
\text { de dicha explotación, el gobierno propiciará la participación de los repre- } \\
\text { sentantes de las respectivas comunidades (parágrafo del artículo 330 de } \\
\text { la Constitución Política de Colombia). }\end{array}$ \\
\hline
\end{tabular}

Continúa 


\begin{tabular}{|c|c|}
\hline Norma & Contenido \\
\hline $\begin{array}{l}\text { Ley General Ambiental } \\
\text { Ley } 99 \text { de } 1993\end{array}$ & $\begin{array}{l}\text { Art. } 76 \text {. La explotación de los recursos naturales deberá hacerse sin des- } \\
\text { medro de la integridad cultural, social y económica de las comunidades } \\
\text { indígenas, de acuerdo con el artículo } 330 \text { de la Constitución Nacional, y } \\
\text { las decisiones sobre la materia se tomarán, previa consulta a los represen- } \\
\text { tantes de tales comunidades. }\end{array}$ \\
\hline Decreto 1320 de 1998 & $\begin{array}{l}\text { Por el cual se reglamenta la consulta previa a comunidades indígenas y } \\
\text { negras, para la explotación de recursos naturales dentro de su territorio. }\end{array}$ \\
\hline $\begin{array}{l}\text { Directiva Presidencial } \\
\text { No. } 01 \text { de } 2010\end{array}$ & $\begin{array}{l}\text { Reseña los mecanismos para la aplicación de la Ley } 21 \text { de } 1991 \text {, señala } \\
\text { las acciones que requieren la garantía del derecho a la consulta previa } \\
\text { y establece los mecanismos mediante los cuales procede el proceso de } \\
\text { consulta previa. }\end{array}$ \\
\hline $\begin{array}{l}\text { Código de Procedi- } \\
\text { miento Administrativo } \\
\text { y de lo Contencioso } \\
\text { Administrativo. Artí- } \\
\text { culo } 46 .\end{array}$ & $\begin{array}{l}\text { Cuando la Constitución o la ley ordenen la realización de una consul- } \\
\text { ta previa a la adopción de una decisión administrativa, dicha consulta } \\
\text { deberá realizarse dentro de los términos señalados en las normas respec- } \\
\text { tivas, so pena de nulidad de la decisión que se llegare a adoptar. }\end{array}$ \\
\hline $\begin{array}{l}\text { Ley } 1444 \text { de } 2011 \text { y } \\
\text { Decreto } 2893 \text { de } 2011\end{array}$ & $\begin{array}{l}\text { Sobre las competencias del Ministerio del Interior y de las direcciones } \\
\text { con competencias en materia de consulta previa. }\end{array}$ \\
\hline $\begin{array}{l}\text { Decreto ley } 4633 \text { de } \\
2011\end{array}$ & $\begin{array}{l}\text { Por medio del cual se dictan medidas de asistencia, atención, reparación } \\
\text { integral y de restitución de derechos territoriales a las víctimas pertene- } \\
\text { cientes a los pueblos y comunidades indígenas. }\end{array}$ \\
\hline $\begin{array}{l}\text { Directiva Presidencial } \\
\text { No. } 10 \text { de } 2013\end{array}$ & $\begin{array}{l}\text { Por medio de la cual se expide un protocolo que busca regular la coor- } \\
\text { dinación interna de las entidades involucradas, a efectos de garantizar la } \\
\text { integración de las competencias correspondientes y la distribución eficaz } \\
\text { de los recursos, así como a la eficiente circulación de la información } \\
\text { relevante, la transparencia de los procesos y permitir el seguimiento al } \\
\text { cumplimiento de los deberes de las entidades responsables en materia de } \\
\text { consulta previa. }\end{array}$ \\
\hline Decreto 2613 de 2013 & $\begin{array}{l}\text { Por medio del cual se adopta el Protocolo de Coordinación Interinstitu- } \\
\text { cional para la consulta previa }{ }^{86} \text {. }\end{array}$ \\
\hline
\end{tabular}

Fuente: Elaboración de la autora.

\subsection{Asuntos objeto de consulta previa}

En este punto es necesario precisar que se deben consultar todas las medidas administrativas y legislativas susceptibles de afectar directamente estas colectividades. El tribunal constitucional también se ha pronunciado en este sentido y en el caso concreto de proyectos que afectan directamente a los

${ }^{86}$ Es importante señalar que consideramos que es necesario establecer la legalidad de esta norma, toda vez que los mecanismos de participación como la consulta previa deben ser reglamentados mediante una ley estatutaria. 
pueblos indígenas ha aclarado que la realización de la consulta previa en la explotación de recursos naturales en territorios indígenas busca: ${ }^{87}$

Que la comunidad tenga un conocimiento pleno sobre los proyectos destinados a explorar o explotar los recursos naturales en los territorios que ocupan o les pertenecen, los mecanismos, procedimientos y actividades requeridos para ponerlos en ejecución.

Que igualmente la comunidad sea enterada e ilustrada sobre la manera como la ejecución de los referidos proyectos puede conllevar una afectación o menoscabo a los elementos que constituyen la base de su cohesión social, cultural, económica y política y, por ende, el sustrato para su subsistencia como grupo humano con características singulares. Que se le dé la oportunidad para que libremente y sin interferencias extrañas pueda, mediante la convocación de sus integrantes o representantes, valorar conscientemente las ventajas y desventajas del proyecto sobre la comunidad y sus miembros, ser oída en relación con las inquietudes y pretensiones que presente, en lo que concierna a la defensa de sus intereses $y$, pronunciarse sobre la viabilidad del mismo. Se busca con lo anterior, que la comunidad tenga una participación activa y efectiva en la toma de la decisión que deba adoptar la autoridad, la cual en la medida de lo posible debe ser acordada o concertada. (ccc, su-039/97)

De igual forma ha reiterado el máximo tribunal de la jurisdicción constitucional los parámetros para la realización de las consultas previas y ha establecido importantes aportes para la protección y garantía de los derechos de las comunidades étnicas. En este sentido ha dejado claro que la explotación de los recursos naturales en los territorios indígenas debe hacerse compatible con la protección que el Estado debe dispensar a la integridad social, cultural y económica de las comunidades indígenas. La integridad configura un derecho fundamental para los pueblos indígenas por estar ligada a su subsistencia como grupo humano y como cultura. Para asegurar la subsistencia se ha previsto,

\footnotetext{
${ }^{87}$ En relación con el derecho a la consulta previa se sugiere ver, entre otras, la siguiente jurisprudencia de la Corte Constitucional: C-030 de 2008, C-461 de 2008, C-175 de 2009, C-615 de 2009, C-702 de 2010, C-366 de 2011, C-490 de 2011,C-882 de 2011, C-317 de 2012, C-068 de 2013, C-253 de 2013.
} 
cuando se trate de realizar la explotación de recursos naturales en territorios indígenas, la participación de la comunidad en las decisiones que se adopten para autorizar dicha explotación. ${ }^{88}$

Por otro lado, también deben consultarse las medidas legislativas que afecten directamente a los pueblos indígenas, según el máximo tribunal de la jurisdicción constitucional, cuando se desee expedir una medida del orden constitucional, internacional, nacional, departamental o local susceptible de afectar directamente a los pueblos indígenas.

Ahora bien, para el caso particular de las medidas legislativas, la consulta se predica cuando esa normatividad general tenga previsiones expresas que se encuentren comprendidas en el ámbito de aplicación del Convenio 169 de la OIт y que sí interfieran en los intereses de dichas comunidades (ccc, C-175/09).

Sobre las medidas legislativas ${ }^{89}$ que tienen que consultarse, la Corte Constitucional ha señalado que están, por ejemplo, la Ley General de Educación, el Plan Nacional de Desarrollo, una reforma del sistema de seguridad social, el Código Laboral o el Código Penal. Por esta razón, además del proceso deliberativo, público y participativo que se surte en el Congreso de la República, dichas medidas deberán someterse a un proceso específico de consulta con las comunidades indígenas y tribales. En este sentido, para el tribunal constitucional es claro que lo que debe ser objeto de consulta son aquellas medidas susceptibles de afectar específicamente a las comunidades indígenas en su calidad de tales y no aquellas disposiciones que se han previsto de manera uniforme para la generalidad de los colombianos (ccc, C-030/08).

Con el fin de aclarar el alcance, a juicio de la Corte Constitucional, de igual forma el concepto de medida legislativa cobija los actos legislativos, pues considera que la expresión "medidas legislativas" no puede ser entendida en un sentido restringido, alusivo en forma estricta a la ley en sentido formal,

88 Para el tribunal constitucional, el derecho fundamental de la comunidad a preservar la integridad se garantiza y efectiviza a través del ejercicio de otro derecho que también tiene el carácter de fundamental, como es el derecho a la participación de la comunidad en la adopción de las referidas decisiones. La participación de las comunidades indígenas en las decisiones que pueden afectarlas en relación con la explotación de los recursos naturales ofrece como particularidad el hecho que la referida participación, a través del mecanismo de la consulta, adquiere la connotación de derecho fundamental, pues se erige en un instrumento que es básico para preservar la integridad étnica, social, económica y cultural de las comunidades de indígenas y para asegurar, por ende, su subsistencia como grupo social (ccc, su 039/97).

89 Para profundizar en el tema se sugiere ver, entre otras, las siguientes providencias de la Corte Constitucional colombiana: C-030/08, C- 461/08, C-175/09, C-615/09 y C-941/10. 
sino en uno amplio que cobije todo tipo de medidas normativas susceptibles de afectar directamente a dichas comunidades. Adicionalmente, señala el tribunal constitucional que de acuerdo con una interpretación pro homine, ${ }^{90}$ la exégesis de la expresión "medidas legislativas" que debe ser escogida es aquella que permita ampliar el espectro de ejercicio del derecho fundamental de las comunidades étnicas. Por último, asegura que en el derecho constitucional colombiano, la palabra ley no tiene un sentido unívoco y, por tanto, el adjetivo legislativo tampoco lo tiene (ccc, C-702/1091).

Así las cosas, el alto tribunal constitucional ha planteado unos requisitos para la consulta previa en materia legislativa, la cual considera que tiene unas características especiales y que debe sustituirse con un proceso participativo en el que de manera general se cumpla con los siguientes requisitos: (a) poner en conocimiento el proyecto de ley a las comunidades, por intermedio de instancias suficientemente representativas; (b) ilustrarlas sobre su alcance y sobre la manera como podría afectarlas y, (c) darles oportunidades efectivas para que se pronunciaran sobre el mismo (ccc, C-175/09). De manera reiterada esta corporación ha señalado estos requisitos y que además se deben haber propiciado espacios y escenarios de discusión que sean apropiados para el conocimiento de la norma y para la realización de la consulta previa (cCC, $\mathrm{C}-030 / 08)$.

De otro lado, en relación con los tratados internacionales, la Corte Constitucional (ccc, C-615/0992) ha señalado que con el propósito de que se pueda adelantar un verdadero diálogo intercultural, en estos casos, la consulta previa debe llevarse a cabo antes que el presidente de la república someta el instrumento internacional al Congreso de la República, o bien durante la negociación, por ejemplo, mediante la creación de mesas de trabajo, caso en el cual las comunidades indígenas podrán aportar insumos a la discusión del

${ }^{90}$ Este principio significa la necesidad de imponer la aplicación de las normas jurídicas más favorables al ser humano y sus derechos.

${ }^{91}$ Demanda de inconstitucionalidad en contra del inciso 8 del artículo 2 del Acto Legislativo 01 de 2009, "Por el cual se modifican y adicionan unos artículos de la Constitución Política de Colombia". Dicha norma fue declarada inexequible por falta de consulta previa.

${ }_{92}$ Correspondiente a la revisión automática del "Acuerdo para el Desarrollo Integral y Asistencia Básica de las Poblaciones Indígenas Wayúu de la República de Colombia y de la República de Venezuela”, firmado en Caracas el tres (3) de mayo de 1990, así como de la Ley 1214 de 2008, mediante la cual fue aprobado. Fue declarado inexequible por falta de consulta previa. 
articulado del instrumento internacional o manifestar sus preocupaciones frente a determinados temas que los afectan; o ya cuando se cuente con un texto aprobado por las partes, es decir, luego de la firma del tratado, caso en el cual la consulta podría llevar a la necesidad de renegociar el mismo. Lo anterior no significa, por supuesto, que las comunidades indígenas no puedan servirse de los espacios que suelen abrirse durante los debates parlamentarios con el propósito de ilustrar a los congresistas acerca de la conveniencia del instrumento internacional, o que igualmente intervengan ante la corte al momento de analizar la constitucionalidad de aquél.

En este marco, de igual forma también se deben consultar las leyes tanto de iniciativa parlamentaria como de iniciativa del gobierno. El gobierno tiene el deber de promover la consulta y, además, debe brindarle a las comunidades, en un momento previo a la radicación del proyecto en el Congreso de la República, las debidas oportunidades para que ellas no sólo conozcan a fondo el proyecto, sino que puedan participar activamente e intervenir en su modificación, si es preciso (ccc, C-891/02).

Cuando en desarrollo de la iniciativa que les confiere la Constitución otros sujetos distintos del gobierno ${ }^{93}$ deciden presentar a consideración de las cámaras legislativas proyectos de ley cuyo contenido sea susceptible de afectar de manera directa a las comunidades indígenas, según la Corte Constitucional (C-030/08), parecería necesario que el gobierno, tan pronto advierta que cursa un proyecto de ley en relación con el cual debe darse el proceso de consulta, acuda a las instancias que para ese efecto se hayan previsto en la legislación, como la Mesa Permanente de Concertación ${ }^{94}$ con los Pueblos y Organizaciones Indígenas. En todo caso, cuando se realizan consultas nacionales amplias, existe la necesidad de adoptar un enfoque incluyente, que permita la participación de diversas expresiones organizacionales (огт 2013,15).

\footnotetext{
${ }^{93}$ Constitución Política, art. 155: "Podrán presentar proyectos de ley un número de ciudadanos igual o superior al cinco por ciento del censo electoral existente en la fecha respectiva o el treinta por ciento de los concejales o diputados del país. La iniciativa popular será tramitada por el Congreso, de conformidad con lo establecido en el artículo 163, para los proyectos que hayan sido objeto de manifestación de urgencia”.

${ }^{94}$ Mediante el Decreto 1397 de 1996 se crea la Mesa Permanente de Concertación con los pueblos y organizaciones indígenas (MPC), adscrita al Ministerio del Interior, que tiene por objeto concertar entre estos y el Estado todas las decisiones administrativas y legislativas susceptibles de afectarlos, evaluar la ejecución de la política indígena del Estado y hacerle seguimiento al cumplimiento de los acuerdos a que allí se lleguen (este tema será abordado más adelante).
} 
Así las cosas, la consulta debe efectuarse en un momento previo a la radicación del proyecto en el Congreso de la República, para que los resultados del proceso de participación incidan en el contenido de la iniciativa que se somete a consideración. No obstante, durante el trámite legislativo en el Congreso de la República dicho proceso participativo no se interrumpe (ccc, C-293/12).

Algo muy importante a tener en cuenta es que la consulta previa se debe hacer con el pueblo indígena en general, no solamente con sus instancias de representación o solamente con la Mesa Permanente de Concertación (ccc, C-702/10).

Con el fin de avanzar y prevenir futuras confrontaciones en los temas procedimentales, la Corte Constitucional (T-382/06) ha planteado la posibilidad de usar talleres preparatorios en los cuales se informe debidamente a los pueblos indígenas cuáles son las medidas normativas a presentar y qué tipo de consecuencias pueden tener estas sobre cada pueblo, para después efectuar la Mesa de Concertación respectiva.

También la Corte Constitucional ha dado luces sobre las consultas previas en cuanto a los planes de desarrollo que pueden contener programas, proyectos y presupuestos que inciden de manera directa y específica en los pueblos indígenas y las comunidades afrodescendientes que residen en las zonas de aplicación de los mismos. En este caso, dicha consulta previa debe ser realizada con pleno cumplimiento de todos sus requisitos, porque de lo contrario se presentaría un vicio de inconstitucionalidad, es decir, se estaría violando la Constitución Política de Colombia (ccc, C-461/0895).

En este mismo sentido, sobre la consulta de la Ley del Plan Nacional de Desarrollo el tribunal constitucional (C-461/08) también señala que en estos casos se deben determinar previamente cuáles son los proyectos o programas incluidos en el mismo que deben agotar el requisito de consulta. Esta es una responsabilidad del gobierno nacional, por ser el respectivo proyecto de ley de su iniciativa. El derecho a la consulta previa es un mecanismo necesario

\footnotetext{
95 Demanda de inconstitucionalidad contra la Ley 1151 de 2007, "por la cual se expide el Plan Nacional de Desarrollo 2006-2010". La Corte Constitucional declara inexequible esta norma, en el entendido de que suspende la ejecución de cada uno de los proyectos, programas o presupuestos plurianuales incluidos en la misma que tengan la potencialidad de incidir directa y específicamente sobre pueblos indígenas o comunidades étnicas afrodescendientes, hasta tanto se realice en forma integral y completa la consulta previa específica exigida por el bloque de constitucionalidad, de conformidad con las pautas trazadas para ello por la jurisprudencia constitucional.
} 
e indispensable para asegurar que la realización de estos proyectos no afecte en forma irreversible las formas tradicionales de subsistencia de los indígenas dentro de sus territorios, las cuales forman parte integrante de su estructura cultural propia y proveen la base para la preservación y el desarrollo en el tiempo de sus cosmogonías, saberes ancestrales y formas culturales.

En este orden de ideas, afirma la corte que, en efecto, el derecho fundamental a la subsistencia de los indígenas se puede ver drásticamente afectado por los cambios abruptos, de índole social, cultural y medioambiental inducidos por la realización de proyectos en territorios indígenas que no han sido debidamente consultados, cuyas condiciones no se han acordado con las comunidades directa y específicamente afectadas.

A lo anterior debemos agregar que la Corte IDH (2007) señala que, al garantizar la participación efectiva de una comunidad en los planes de desarrollo o inversión que se darán en su territorio, el Estado tiene el deber de consultar, activamente, con dicha comunidad, según sus costumbres y tradiciones. Este deber requiere que el Estado acepte y brinde información, lo cual implica una comunicación constante entre las partes.

\subsection{Resultado de la consulta previa}

Consideramos pertinente mencionar en esta parte que lo que se pretende con la consulta previa es llegar a un acuerdo o lograr el consentimiento. La Corte Constitucional (su-039/97) estableció que cuando no sea posible el acuerdo o la concertación, la decisión de la autoridad debe estar desprovista de arbitrariedad y de autoritarismo; en consecuencia, esta debe ser objetiva, razonable y proporcionada a la finalidad constitucional que le exige al Estado a la protección de la identidad social, cultural y económica de la comunidad indígena. Para este tribunal (C-175/09), el ejercicio de esa potestad carece de naturaleza omnímoda y en cambio debe estar desprovista de arbitrariedad y autoritarismo; fundarse como se ha mencionado en parámetros de objetividad, razonabilidad y proporcionalidad en cuanto al grado de afectación de los intereses de las comunidades tradicionales; contemplar instrumentos idóneos para mitigar el impacto de la medida en dichos intereses, tanto en el plano individual como colectivo, todo ello con miras a salvaguardar las prácticas que conforman la diversidad étnica y cultural. 


\subsection{Sobre el consentimiento libre, previo e informado (CLPI)}

$\mathrm{El}$ antecedente más relevante del CLPI lo encontramos en la Corte Interamericana de Derechos Humanos, que en el caso del pueblo Saramaka versus Surinam (Sentencia del 28 de noviembre de 2007) señaló que cuando se trate de planes de desarrollo o de inversión a gran escala que tendrían un mayor impacto dentro del territorio, el Estado tiene la obligación, no sólo de consultar, sino también debe obtener el consentimiento libre, previo e informado de estos, según sus costumbres y tradiciones.

La Declaración de Naciones Unidas sobre los Derechos de los Pueblos Indígenas, en su artículo 19, señala que "Los Estados celebrarán consultas y cooperarán de buena fe con los pueblos indígenas interesados por medio de sus instituciones representativas antes de adoptar y aplicar medidas legislativas y administrativas que los afecten, para obtener su consentimiento libre, previo e informado".

Se ha considerado que también se requiere el CLPI en situaciones como: almacenamiento de desechos tóxicos, traslado de grupos indígenas y proyectos de inversión de gran escala en territorios indígenas donde se genera un impacto significativo sobre el ejercicio de una serie de derechos de los pueblos indígenas. Esto generalmente hace difícil que en los referidos eventos pueda demostrarse una necesidad y proporcionalidad sin el consentimiento de la parte indígena, aun asumiendo que existe un propósito estatal válido (Anaya 2013).

En este mismo sentido, el ex relator especial de la onu determinó que es esencial el consentimiento libre, previo e informado para la protección de los derechos humanos de los pueblos indígenas en relación con grandes proyectos de desarrollo. Asegura que mientras el Convenio 169 y la declaración se refieren a la consulta como una obligación o deber de los Estados, entre actores institucionales y los que abogan por los pueblos indígenas se ha venido hablando cada vez más del derecho de estos pueblos a ser consultados. Es importante recordar, sin embargo, que este derecho es corolario de la consulta, tal como se plantea en los instrumentos y jurisprudencia internacionales, no es un derecho aislado o independiente. Más bien la norma de consulta, con su principio conexo de consentimiento libre, previo e informado, se presenta en el derecho internacional como una salvaguarda para el conjunto de derechos sustantivos de los pueblos indígenas que pueden ser afectados por las decisiones administrativas o legislativas de los Estados (Anaya 2013). 
Precisando lo anterior, en el caso colombiano la Corte Constitucional (T-129/1196) encuentra necesario que la consulta previa y el consentimiento informado de las comunidades étnicas en general pueda determinar la alternativa menos lesiva, cuando existan proyectos que tengan el potencial de poner en peligro sus formas de vida y específicamente en aquellos eventos que: (a) impliquen el traslado o desplazamiento de las comunidades por la obra o el proyecto; (b) estén relacionados con el almacenamiento o vertimiento de desechos tóxicos en las tierras étnicas; (c) representen un alto impacto social, cultural y ambiental en una comunidad étnica, que conlleve a poner en riesgo la existencia de la misma, entre otros.

Cabe destacar que no sólo se debe obtener el cLPI de las comunidades cuando existen planes para llevar a cabo grandes actividades de explotación en territorios indígenas, sino que obtenida su aprobación debe garantizarse que se compartan los beneficios derivados de dicha explotación en forma equitativa (ccc, T-129/11). En consecuencia, el CLPI opera en los siguientes casos, según la Corte Constitucional (T-769/09 y T-129/11):

Cuando se trate de planes de desarrollo o de inversión a gran escala, que tengan mayor impacto dentro del territorio de los pueblos indígenas, es deber del Estado no sólo consultar a dichas comunidades, sino también obtener su CLPI, según sus costumbres y tradiciones. Para este tribunal, al ejecutarse planes e inversiones de exploración y explotación en su hábitat, estos pueden conllevar a: (a) cambios sociales y económicos profundos; (b) la pérdida de sus tierras

${ }^{96}$ Los integrantes del resguardo Chidima-Tolo y Pescadito, ubicado en el municipio de Acandí (Chocó), y pertenecientes a la etnia embera katío, interpusieron acción de tutela en contra de los ministerios de Transporte, Ambiente, Vivienda y Desarrollo Territorial, Interior y de Justicia, de Minas y Energía, de Agricultura, de Defensa, el Consejo Asesor de Regalías adscrito al Departamento Nacional de Planeación, las alcaldías de Unguía y Acandí, la Corporación Autónoma Regional del Chocó (Codechocó), el Ejército Nacional, la Brigada xvi y la Agencia Logística de las Fuerzas Militares, por considerar vulnerados sus derechos a la consulta previa, a la participación, a la propiedad colectiva, a no ser desplazados, al debido proceso, al reconocimiento de la diversidad étnica y cultural de la Nación, a la vida y subsistencia como pueblo indígena. Los problemas generales por las que interponen la acción y por la que solicitan que se protejan sus derechos pueden ser resumidos en los siguientes términos: (i) los trabajos correspondientes a una carretera que atravesaría los resguardos; (ii) el proyecto de interconexión eléctrica entre Colombia y Panamá; (iii) los trámites de concesión minera para explotación de oro; y (iv) la invasión ilegal del territorio, así como el peligro de desplazamiento por la expectativa económica de las obras y proyectos. La Corte Constitucional concede la protección de los derechos fundamentales a la consulta previa con las comunidades étnicas y a la existencia, autonomía, integridad e identidad cultural y social de tales pueblos, al igual que a la protección de las riquezas naturales y culturales de la nación. Además da diferentes órdenes a las instituciones mencionadas. 
tradicionales, el desalojo, la migración, el agotamiento de recursos necesarios para la subsistencia física y cultural y (c) la destrucción y contaminación del ambiente tradicional, entre otras consecuencias. Así, en estos casos, las decisiones de las comunidades indígenas se consideran vinculantes, debido al alto grado de afectación que les acarrea y el cLPI implica la aplicación del principio pro bomine.

La Corte Constitucional (T-129/11) también encuentra necesario que la consulta previa y el consentimiento informado de las comunidades étnicas en general pueda determinar la alternativa menos lesiva o exigir, como se ha mencionado, la aplicación del principio pro homine en aquellos eventos anteriormente señalados. Dicho principio significa que, en todo caso, siempre se da aplicación a las normas jurídicas que son más favorables al ser humano y sus derechos. En otras palabras, prima la imposición de aquella interpretación que propenda por el respeto de la dignidad humana y consecuentemente por la protección, garantía y promoción de los derechos humanos y de los derechos fundamentales contemplados en la Constitución Política.

En ese sentido, toda medida sobre de infraestructura, de proyecto u obra que intervenga o tenga la potencialidad de afectar territorios indígenas o étnicos deberá agotar no sólo el trámite de la consulta previa desde el inicio, sino que se orientará bajo el principio de participación y reconocimiento en un proceso de diálogo entre iguales que tendrá como fin el cLPI de las comunidades étnicas implicadas. En este contexto, aclara el máximo tribunal constitucional, que la intervención del Estado o concesionarios del proyecto en estos territorios debe estar irradiada desde la etapa de planificación o proyección no sólo del derecho fundamental a la consulta previa, sino que existe la obligación de estar enfocada en conseguir el consentimiento libre, previo e informado de las comunidades y pueblos étnicos. Sumado a ello, insiste en el derecho de compartir los beneficios derivados de los proyectos y obras que se realicen en los territorios de estas comunidades.

Sobre el particular, la misma Corte Constitucional (T-129/11) ha señalado que conforme al desarrollo normativo y jurisprudencial actual no es fácil este tema, puesto que está ante un problema de dos extremos difíciles. Por un lado, está la consulta previa veto (que estaría dentro de los términos del Convenio 169, pero que genera todo tipo de resistencia) y la consulta previa mera información (que no estaría conforme con la convención y que con frecuencia es empleada para aparentar un cumplimiento de dicho 
instrumento). Conforme a lo expuesto, para la corte el criterio que permite conciliar estos extremos depende del grado de afectación de la comunidad, de los eventos específicos en que la consulta y el consentimiento pueden incluso llegar a determinar la medida menos lesiva, como medida de protección de las comunidades y pueblos indígenas. Por ello, según este tribunal, todo proceso deberá cualificarse conforme a las características propias de cada caso concreto, pues lo que está de por medio no es sólo la expectativa de recibir ciertos beneficios económicos por un proyecto económico, sino entender y reconocer que lo que se discute es el presente y futuro de un pueblo, de un grupo de seres humanos que tiene derecho a autodeterminarse y defender su existencia física y cultural, por "absurdas o exóticas" que para algunos puedan parecer sus costumbres y modos de vida.

En síntesis, para el tribunal constitucional es fundamental lograr el cLPI porque en los casos mencionados se generan cambios sociales y económicos profundos; se presenta la pérdida de sus tierras tradicionales, el desalojo y la migración. Adicionalmente, se puede dar el agotamiento de recursos necesarios para la subsistencia física y cultural, la destrucción y contaminación del ambiente tradicional, entre otras consecuencias.

Termina asegurando la Corte Constitucional (T-129/11) que si se tienen en cuenta los presupuestos, al igual que los factores señalados anteriormente, se espera que el proceso de consulta previa y participación respete de forma integral los derechos en juego en estos tipos de casos, como la subsistencia e integridad cultural de los pueblos étnicos. No obstante, es necesario tener en cuenta que efectuar la consulta previa y buscar el consentimiento informado no justifica la violación material futura de los derechos fundamentales de los grupos afectados por una actuación o autorización administrativa de entidades del Estado o particulares. En esta circunstancia habrá lugar a la responsabilidad del Estado o de los concesionarios conforme a la normativa interna e internacional.

\subsubsection{Derecho a la participación ${ }^{97}$}

Colombia se considera un Estado democrático y participativo, que con la Constitución Política consagrada en 1991 puede garantizar el derecho fundamental

\footnotetext{
${ }^{97}$ En relación con el derecho a la participación se sugiere ver la siguiente jurisprudencia de la Corte Constitucional: su-039 de 1997,T-652 de 1998,T-634 de 1999,T-116 de 2001, C-418 de 2002, C-891
} 
a la participación. Los pueblos indígenas cuentan además con mecanismos como la consulta previa, que les proporciona la capacidad de participar en las decisiones que puedan interesarles. Tan es así, que el Estado colombiano debe consultar a estos pueblos cada vez que se prevean medidas que puedan afectarlos y debe establecer mecanismos con los que puedan participar libremente y en todos los espacios e instancias, cuando se trata de la adopción de decisiones relacionadas con políticas y programas que los involucren.

Los pueblos indígenas también tienen el derecho de participar en la formulación, aplicación y evaluación de planes y programas de desarrollo nacional y regional que los involucren, los cuales deben propender por el mejoramiento de sus condiciones de vida, de trabajo, de salud y de educación. Asimismo, en el caso de la educación, con el fin de responder a sus necesidades, los programas y servicios deberán desarrollarse y aplicarse con su cooperación.

La Corte Constitucional establece (C-187/1198), acogiéndose a la legislación y a los derechos de los pueblos indígenas, los siguientes espacios y mecanismos de participación:

a) La elección de dos senadores en circunscripción nacional especial por comunidades indígenas.

b) La posibilidad de establecer una circunscripción especial en la Cámara de Representantes, para asegurar la participación de los grupos étnicos.

c) La obligación de que participen los representantes de las comunidades y pueblos indígenas en la conformación y delimitación de las entidades territoriales indígenas, previo concepto de la comisión de ordenamiento territorial (artículo 329).

de 2002, C-620 de 2003, T-955 de 2003, su-383 de 2003, C-245 de 2004, C-382 de 2006, T-880 de 2006, C-030 de 2008, C-461 de 2008, C-750 de 2008, C-175 de 2009, C-615 de 2009, T-154 de 2009, T-769 de 2009, C-063 de 2010, C-608 de 2010, C-702 de 2010, C-915 de 2010, C-941 de 2010,T-547 de 2010, T-745 de 2010, T-1045A de 2010, C-027 de 2011, C-187 de 2011, C-367 de 2011, C-366 de 2011 y T-129 de 2011.

${ }^{98}$ Revisión de constitucionalidad del "Acuerdo en materia de informes anuales sobre derechos humanos y libre comercio entre la República de Colombia y Canadá hecho en Bogotá el día 27 de mayo de 2010" y la Ley 1411 de 2010 que lo aprueba. 
d) El mandato de propiciar la participación de los representantes de las comunidades y pueblos indígenas en las decisiones con respecto a la explotación de los recursos naturales en sus territorios (artículo 330).

e) La consulta previa sobre las medidas legislativas y administrativas que los afectan directamente, espacio de participación relevante.

Es necesario tener presente que, para el alto tribunal constitucional, el reconocimiento simultáneo de la participación democrática como base del Estado constitucional y de la necesidad de preservación de la identidad de las comunidades tradicionales contrae deberes concretos para el Estado. En efecto, la concurrencia de ambas obligaciones implica que los pueblos indígenas deben contar con los espacios suficientes y adecuados de participación en las decisiones que incidan en sus intereses. Ello con el fin de evitar que, a través del ejercicio del poder político en los que son titulares los órganos representativos, sean implementadas políticas públicas que terminen por erosionar su identidad como grupo diferenciado.

A partir de esta consideración, la Carta consagra diversos instrumentos, como: (a) la necesidad que la conformación de las entidades territoriales se lleve a cabo con participación de los representantes de las comunidades indígenas, previo concepto de la comisión de ordenamiento territorial (CP, art. 329); (b) el carácter colectivo y no enajenable de la propiedad de los resguardos; y (c) el deber consistente en que la explotación de los recursos naturales en los territorios indígenas se lleve a cabo sin desmedro de la integridad cultural, social y económica de las comunidades. Para ello, el gobierno deberá propiciar la participación de los representantes de las respectivas comunidades (CP, art. 330, parágrafo; ccc, C-175/09).

De igual forma, este derecho se encuentra consagrado en el art. 18 de la DNUDPI, al establecer que los pueblos indígenas tienen derecho a participar en la adopción de decisiones en las cuestiones que afecten sus derechos, por conducto de representantes elegidos por ellos de conformidad con sus propios procedimientos, así como a mantener y desarrollar sus propias instituciones de adopción de decisiones.

\subsection{Jurisprudencia sobre el derecho a la participación}

Para la Corte Constitucional, este derecho de los indígenas a participar en aspectos que tienen que ver con su población y su territorio se liga al derecho 
a la identidad como etnia porque tiene relación con la supervivencia cultural, y encuentra su fundamento en las normas de la Constitución y en el derecho a la libre autodeterminación de los pueblos. Ahora bien, corresponde a cada Estado señalar, ya sea en la Constitución o en la ley, los mecanismos idóneos para hacer efectiva la participación de las comunidades como un instrumento de protección de los intereses de estas que, como ya se expresó, configuran proyección de los intereses de la propia sociedad y del Estado (ccc, T-634/9999 y C-418/02).

Resalta este alto tribunal que la jurisprudencia constitucional ha coincidido en apreciar que el proceso de participación de los grupos étnicos en la toma de las decisiones estatales, cuando estas proyectan sus efectos sobre los intereses de tales grupos, están llamadas a desarrollarse dentro de un marco de derecho internacional y constitucional fuertemente garantista, que no se caracteriza por ser un simple ejercicio jurídico de respeto del derecho de defensa de quienes pueden verse afectados con una actuación del Estado, sino porque se busca asegurar por medio de esta consulta previa la efectiva protección de los intereses colectivos y derechos fundamentales de las referidas comunidades (ccc, C-208/07, T-737/05, T-380/93, su-039/97 y su-383/03).

En este marco, afirma la Corte Constitucional (C-030/08) que, en lo referente al derecho general de participación, el Convenio 169 está orientado a garantizar a los pueblos interesados unas oportunidades de participación que sean, al menos, equivalentes a las que están a disposición de otros sectores de la población, en la adopción de decisiones en instituciones electivas y organismos administrativos y de otra índole responsables de políticas y programas que les conciernan.

El principio general de participación para la Corte Constitucional comprende a todos los habitantes del territorio colombiano; es reforzado en el caso de las comunidades étnicas - indígenas y afrodescendientes - en virtud de la definición del Estado colombiano como república pluralista — por el artículo 1 de la Constitución Política- y del reconocimiento y protección

\footnotetext{
${ }^{99}$ Acción de la tutela interpuesta por la procuradora delegada para asuntos étnicos, en la cual pide que se respeten los derechos fundamentales del pueblo arhuaco, pues este no fue tenido en cuenta en la creación del municipio de Pueblo Bello (Cesar). La acción estuvo dirigida contra el gobernador del departamento del Cesar, el registrador nacional del estado civil y el registrador departamental del Cesar. La Corte Constitucional no concede la tutela impetrada como mecanismo transitorio, porque considera que existen otras vías judiciales: la acción popular y la contencioso-administrativa.
} 
de la diversidad étnica y cultural de la nación colombiana — artículos 7 y 70, también de la Constitución-. En este sentido, la jurisprudencia de la corte ha indicado que las normas constitucionales derivan en que la Carta Política propugna por un modelo de Estado que se reconoce como culturalmente heterogéneo y que, por ende, está interesado en la preservación de esas comunidades diferenciadas, a través de la implementación de herramientas jurídicas que garanticen su identidad como minoría étnica y cultural, organizadas y reguladas mediante sus prácticas tradicionales. Una de estas herramientas es, precisamente, la participación en las decisiones que las afectan, pues así se asegura que en la implementación de las políticas públicas se tome en cuenta su punto de vista. Es por ello que existen previsiones constitucionales expresas, que imponen deberes particulares a cargo del Estado, dirigidos a la preservación de las mismas y la garantía de espacios suficientes y adecuados de participación. En este sentido, el ordenamiento constitucional abre a las comunidades y pueblos indígenas espacios concretos de participación, además de los establecidos para todos los colombianos dentro de los cuales también están incluidos (ccc, C-187/11 y C-175/09).

Igualmente, la corte (C-418/02, T-188/93, T-342/94, su-039/97 y C-825/01) ha estudiado en forma detenida lo relativo a las características, alcance y efectos de la proyección del derecho de participación, como garantía de efectividad y realización del derecho fundamental a la integridad cultural, social y económica de las comunidades y pueblos indígenas cuando de la explotación de los recursos naturales se trata. Ha establecido como rasgos especiales del mismo los siguientes: 1) Constituye un instrumento básico para preservar la integridad étnica, social, económica y cultural de las comunidades indígenas y para asegurar, por ende, su subsistencia como grupo social; y 2) No se reduce a una intervención en la actuación administrativa dirigida a asegurar el derecho de defensa de quienes van a resultar afectados con la autorización de la licencia ambiental, sino que tiene una significación mayor por los altos intereses que ella busca tutelar, como son los atinentes a la definición del destino y la seguridad de la subsistencia de las referidas comunidades.

\subsection{Laparticipación es un derecho fundamental}

Participar significa tomar parte de algo, ser parte de algo, incidir en algo. Es un derecho fundamental y también es un deber que representa la posibilidad de los ciudadanos y de las comunidades para tomar parte en las decisiones y 
ejecutar sus derechos. La participación es el cimiento del Estado y de la democracia; un deber y un derecho que se sustenta en el principio de solidaridad y en la unión de las comunidades en pos de un objetivo o de la integración de todas las personas en la construcción de un mejor país. La Corte Constitucional (su-039/97) ha resaltado la importancia de la participación de los pueblos indígenas, señalando que su carácter de derecho fundamental (CP, art. 40-2) tiene un reforzamiento en el Convenio 169.

Es necesario precisar que el debate sobre los derechos de los pueblos indígenas ha centrado su atención más recientemente en los derechos que, además de permitirles participar en la adopción de decisiones que les afecten, los habilitan para controlar el resultado de esos procesos (Ariza Santamaría 2012, 286).

\subsection{Incidencia y participación de los pueblos indígenas}

Participar es la posibilidad que tienen los individuos y las colectividades para sentirse parte de una comunidad política mediante el libre ejercicio de derechos y deberes. La participación concreta en la realidad, lo que de manera formal se establece en la norma (la igualdad ante la ley) y abre la posibilidad para que sectores tradicionalmente marginados de la política, puedan intervenir en la escena pública y contribuir a la definición de metas colectivas (González y Velásquez 2003, 56).

La participación implica ir más allá de las normas o de las urnas porque representa, además, el poder de las decisiones. Mediante el ejercicio legítimo de la participación es posible contribuir en el devenir de la comunidad y de los pueblos. Este proceso puede ser individual o colectivo y no necesariamente se agota con la mera asistencia a reuniones en las cuales no hay la posibilidad de proponer, sugerir o incidir de manera real y efectiva, sino que este debe llevarse a cabo a través de actividades concretas que permitan la incidencia, el diálogo y la cogestión en las decisiones finales.

El derecho y el deber de las comunidades y de los ciudadanos de participar lo encontramos fundamentado en el artículo $1^{\circ}$ de la Constitución Política, que establece que Colombia es un Estado social de derecho, organizado en forma de república unitaria, descentralizada, con autonomía de sus entidades territoriales, democrática, participativa y pluralista, basada en el respeto de la dignidad humana, en el trabajo y la solidaridad de las personas que la integran y en la prevalencia del interés general. Los pueblos indígenas tienen derecho a 
participar plenamente — si lo desean — en la vida política, económica, social y cultural del Estado.

De acuerdo con el artículo 2o del Convenio 169 de la oit, el Estado colombiano debe asumir la responsabilidad de desarrollar, con la participación de los pueblos indígenas, mecanismos para proteger los derechos de esos pueblos y garantizar el respeto de su integridad. En este sentido, particularmente en el caso de los pueblos indígenas existentes en nuestro país, la Carta Política estableció diversos mecanismos referidos al derecho de participación:

a) Participar en el ejercicio y control del poder político para lograr la efectividad de los derechos (art. 40);

b) Participar en la dirección, financiación y administración de los servicios educativos estatales (art. 67);

c) Derecho a la participación en las decisiones ambientales tanto administrativas como legislativas que puedan afectar sus territorios (art. 79);

d) El derecho de participación política representativa y a su elección mediante circunscripción especial. Los representantes de las comunidades y pueblos indígenas que aspiren a integrar el Congreso de la República deben haber ejercido un cargo de autoridad tradicional en su respectiva comunidad o haber sido líderes de una organización indígena (arts. 171 y 176);

e) Para la explotación de los recursos naturales en los territorios indígenas, que debe realizarse sin desmedro de la integridad cultural, social y económica de las comunidades y pueblos indígenas, y en las decisiones que se adopten en este caso, se debe contar con la participación de los representantes de las respectivas comunidades (art. 330, parágrafo);

f) Los representantes de los pueblos indígenas tienen derecho a participar en la conformación y delimitación de las entidades territoriales que sean previstas en la Ley Orgánica de Ordenamiento Territorial (art. 329);

g) Derecho a participar y concertar con el gobierno nacional los planes de desarrollo (art. 339). 
Los pueblos indígenas pueden ejercer la participación de diferentes formas y con diversos mecanismos. Estos pueblos se caracterizan porque los procesos de decisión en sus comunidades se llevan a cabo con actividades en las que todos sus miembros juegan un papel activo. No obstante, aseguran ellos mismos, la participación debe ser voluntaria y nadie puede ser obligado a ejercerla (csj y onic 2006, 47).

En este contexto, le corresponde al Estado colombiano establecer los medios que permitan que estos pueblos participen en la toma de decisiones en todas las instancias de las instituciones legislativas y de organismos administrativos. Sobre el particular, la Observación de la Comisión de Expertos ${ }^{100}$ (2008) resaltó que debido a los grandes retos a los que actualmente tienen que hacer frente los pueblos indígenas, incluidas la regulación de la propiedad de la tierra, la salud, la educación y el aumento de la explotación de los recursos naturales, su participación en estos y otros ámbitos que les afecten directamente es un elemento fundamental para garantizar la equidad y la paz social, por medio de la inclusión y del diálogo (оіт 2009, 60).

En consecuencia, es responsabilidad del Estado colombiano contribuir a la organización, promoción y capacitación de los pueblos indígenas, sin detrimento de su autonomía, con el objeto de que constituyan y fortalezcan sus mecanismos democráticos de representación en las diversas instancias de participación, concertación, control y vigilancia de la gestión pública.

\subsubsection{Sistema de autoridad de los pueblos indígenas}

Los pueblos indígenas tienen derecho a conservar y reforzar sus propias instituciones políticas, jurídicas, económicas, sociales y culturales, manteniendo a la vez su derecho a participar plenamente, si lo desean, en la vida política, económica, social y cultural del Estado. ${ }^{101}$ Cualquier espacio de participación debe tener presentes las instituciones tradicionales de cada pueblo, sus autoridades y las organizaciones que las representan, que son las indicadas para manifestar las diferentes inquietudes y decisiones. Estas instituciones son

\footnotetext{
${ }^{100}$ La Comisión de Expertos en Aplicación del Convenios se creó con el fin de examinar el creciente número de memorias de los gobiernos sobre los convenios ratificados en la orT. La componen expertos procedentes de diversas regiones geográficas, culturas y sistemas jurídicos. Véase www.ilo.org.

${ }^{101}$ DNUDPI, arts. 5, 18, 20 y 34 .
} 
además las que deben señalar los impactos sociales y culturales que un proyecto o una decisión de cualquier orden pueda generar en sus colectividades.

En ese sentido, tanto la consulta previa como el ejercicio de cualquier mecanismo de participación deben adelantarse teniendo en cuenta la representación y la autoridad de los pueblos indígenas, la interculturalidad y la lengua que interviene en este tipo de procesos sociales.

Es el momento de destacar algunas de las autoridades con las que los pueblos indígenas de Colombia ejercen el control social y resuelven sus conflictos. ${ }^{102}$ Se trata de las instituciones propias encargadas del gobierno interno. En nuestro país pueden ser autoridades tradicionales $u$ otras apropiadas por las comunidades y pueblos.

Las autoridades tradicionales ${ }^{103}$ son los miembros de las comunidades, personas o instituciones de carácter público especial derivado de su condición religiosa, política o cultural propia de un pueblo indígena, localizado en un territorio determinado, reconocido por sus miembros, que ejerce la representación legal de su grupo y las funciones que le atribuyen la ley y su sistema normativo propio. Habitualmente, las autoridades tradicionales representan las personas o instituciones indígenas que ejercen poder en la comunidad de acuerdo con la cultura ancestral. Pueden ser guías espirituales, médicos tradicionales o representantes que dirigen, toman medidas, resuelven conflictos al interior de la comunidad o llevan su vocería fuera de la misma. Dicha autoridad recibe diferentes denominaciones dependiendo del pueblo al que pertenezca: mamo o mamu, werjayá, taita, palabrero, etc.

Es menester señalar que durante la época de la colonia los cabildos indígenas ${ }^{104}$ garantizaban los tributos reales y los pagaban al encomendero o al corregidor. Podría decirse que el cabildo es una autoridad política, reglamentada desde 1890 mediante la Ley 89. Es una entidad pública especial, cuyos

102 Sobre el particular se sugiere ver Arango Ochoa y Sánchez Gutiérrez (2004) y onic (2007a).

103 Según el artículo 2o del Decreto 2164/95, las autoridades tradicionales "son los miembros de la comunidad indígena que ejercen, dentro de la estructura propia de la respectiva cultura, un poder de organización, gobierno, gestión o control social". A efectos de esta norma, las autoridades tradicionales de las comunidades indígenas tienen, frente al Instituto Colombiano de Desarrollo Rural -Incoder-, la entidad encargada de la titulación de sus territorios, la misma representación y atribuciones que corresponde a los cabildos indígenas.

${ }^{104}$ Los cabildos fueron reglamentados más recientemente por el Decreto 2001 de 1988 y el Decreto 2164 de 1995. 
integrantes son miembros de un pueblo o comunidad indígena, elegidos y reconocidos por esta, con una organización sociopolítica tradicional, cuya función es representar legalmente a la comunidad, ejercer la autoridad y realizar las actividades que le atribuyen las leyes, los usos, costumbres y el reglamento interno de cada comunidad.

La autoridad mayor del cabildo es el gobernador, cacique, presidente o capitán, quien cuenta con el apoyo del secretario, el tesorero y los alguaciles, guardias o semaneros, que cumplen funciones policivas. "Eran comúnmente personas experimentadas en el trato con la sociedad nacional o que manejaban el castellano. En algunas comunidades el capitán coincidió con la autoridad tradicional y es quien representa la comunidad ante las autoridades y se encarga de la promoción de eventos y actividades comunales"(Arango Ochoa y Sánchez Gutiérrez, 2004).

Actualmente, aún algunos pueblos indígenas continúan recreando formas de autoridad y de organización de su autoridad indígena tradicional diferente a la del cabildo, lo que obligó al gobierno a reconocer, además de los cabildos y las asociaciones de cabildos, otras formas de autoridad tradicional como las asociaciones de autoridades tradicionales que son específicas para determinado pueblo indígena. Es más, la onu, en su reciente declaración, ha celebrado que los pueblos indígenas se estén organizando para promover su desarrollo político, económico, social y cultural para poner fin a todas las formas de discriminación y opresión dondequiera que ocurran.

Sobre este particular, la Corte Constitucional (T-973/09) resalta que en gran parte de las comunidades y pueblos indígenas el sistema social de mando que gobierna su vida colectiva se rige por normas propias y cargos que se administran según los "usos y costumbres" del grupo étnico y cultural. Las "autoridades tradicionales" resultan ser entonces quienes detentan el poder comunitario, y están conformadas generalmente por los gobernadores y por los cabildos indígenas, quienes llevan consigo símbolos de mando de acuerdo con la tradición. Los cabildos son entidades públicas especiales elegidas y reconocidas, encargadas de representar legalmente a los grupos étnicos y de ejercer las funciones que les atribuyen la ley y sus usos y costumbres. Los gobernadores, por su parte, presiden el cabildo. En tal sentido, asegura este tribunal, se recuerda que compete también a las comunidades indígenas, conforme a su autonomía política y jurídica, lograr que el ejercicio debido de los derechos políticos de sus integrantes se consolide en pro de un desarrollo 
colectivo y constante de sus pueblos. En búsqueda de estos objetivos, las autoridades tradicionales están obligadas a actuar procurando la cohesión social de sus comunidades, la legitimidad real de sus instituciones y siguiendo la tradición y sus usos y costumbres, sin desconocer que el diálogo y la reflexión colectiva pueden significar cambios consensuados en la tradición.

El tema de la representación es fundamental y, en este sentido, la guía para la aplicación del Convenio 169 de la oit señala que, al efectuar la consulta, el gobierno debe realizar estos procesos no con cualquiera que declare representar los pueblos indígenas, sino con organizaciones institucionales genuinamente representativas que estén habilitadas para tomar decisiones o hablar en nombre de las comunidades interesadas. Para ello, antes de iniciar el proceso, debe identificar y verificar que las organizaciones/instituciones con las que tiene previsto tratar cumplan estos requisitos y, además, debe proporcionales información apropiada y completa, la cual debe ser comprendida plenamente. Según las circunstancias, la institución apropiada puede ser de orden nacional, regional o comunitario; hacer parte de una red nacional o representar a una única comunidad. El criterio importante es que la representatividad debe determinarse mediante un proceso del que hagan parte los mismos pueblos indígenas (оіт 2013, 15).

\subsubsection{Los espacios de participación de los pueblos indígenas}

En nuestro contexto, actualmente encontramos diferentes espacios para que los pueblos indígenas puedan incidir en los asuntos que son de su interés (cuadro 1), los cuales corresponden al deber que tiene el Estado de facilitar la participación de todos en las decisiones que los afectan y en la vida económica, política, administrativa y cultural de la nación.

De manera especial queremos destacar tres de estos espacios, los cuales vienen jugado un papel importante en los procesos de participación y en las consultas previas, como se demostrará más adelante en este documento: a) la Mesa Permanente de Concertación de los Pueblos y Organizaciones Indígenas; b) la Comisión Nacional de Territorios Indígenas y, c) Comisión de Derechos Humanos de los Pueblos Indígenas, que tienen un origen común que nace frente a la problemática territorial y al desconocimiento de los pueblos indígenas debido a los incumplimientos del gobierno, principalmente, los derechos establecidos en la Constitución Política de 1991 (MPC 2013, 8). 
Cuadro 1. Algunos espacios de participación de los pueblos indígenas 2013

\begin{tabular}{|ll|}
\hline 1. & Mesa Permanente de Concertación de los Pueblos y Organizaciones Indígenas \\
2. & Consejo Directivo de Instituto Colombiano de Desarrollo Rural, Incoder \\
4. & Comisión Nacional de Territorios Indígenas \\
5. & Consejo Nacional de Planeación \\
6. & Consejo Directivo de la Unidad de Restitución de Tierras \\
7. & Comisión de Seguimiento al decreto 4633 de 2011 (sobre medidas de asistencia, atención,repa- \\
ración integral y restitución de derechos territoriales a las víctimas pertenecientes a los pueblos \\
8. \\
9. Comunidades indígenas) \\
10. Conso de Comunicaciones y Comisión Nacional de Televisión \\
11. Comisión de salud \\
12. Consejo Nacional de Paz \\
13. Mesa Regional Amazónica \\
14. Mesa Awa \\
15. Comité Territorial de Cabildos \\
16. Comité de Evaluación de Riesgo y Recomendación de Medidas (Cerrem) \\
17. Comisión para el Desarrollo Integral de la Política Indígena \\
18. Consejo Ambiental Regional de la Sierra Nevada de Santa Marta \\
19. Comisión Consultiva de las Mujeres Indígenas Rurales \\
20. Consejo Nacional Ambiental \\
21. Consejos directivos de las corporaciones autónomas regionales \\
22. Comisión Nacional de Trabajo y Concertación para la Educación de los Pueblos Indígenas, \\
23. Contas \\
25. Comisión del Departamento Administrativo Nacional de Estadística (DANe) \\
\hline
\end{tabular}

Fuente: Elaboración de la autora.

Fue así que estas instancias fueron fruto de intensos y permanentes procesos de lucha y surgen en especial de la toma que aproximadamente 50 organizaciones de todo el país hicieron en 1996 de la Conferencia Episcopal colombiana, la cual duró 43 días y que fue levantada luego de que el gobierno aceptara las peticiones de los pueblos indígenas que terminaron con la expedición de los decretos 1396 y 1397 (MPC 2013, 8). 
La importancia de estos espacios, radica en la posibilidad que tiene que enfocar las políticas públicas de los pueblos indígenas mediante un diálogo de saberes que le permite contribuir en el devenir de los pueblos en diversos escenarios donde se logra concertar con el gobierno nacional, como se puede establecer en la siguiente figura:
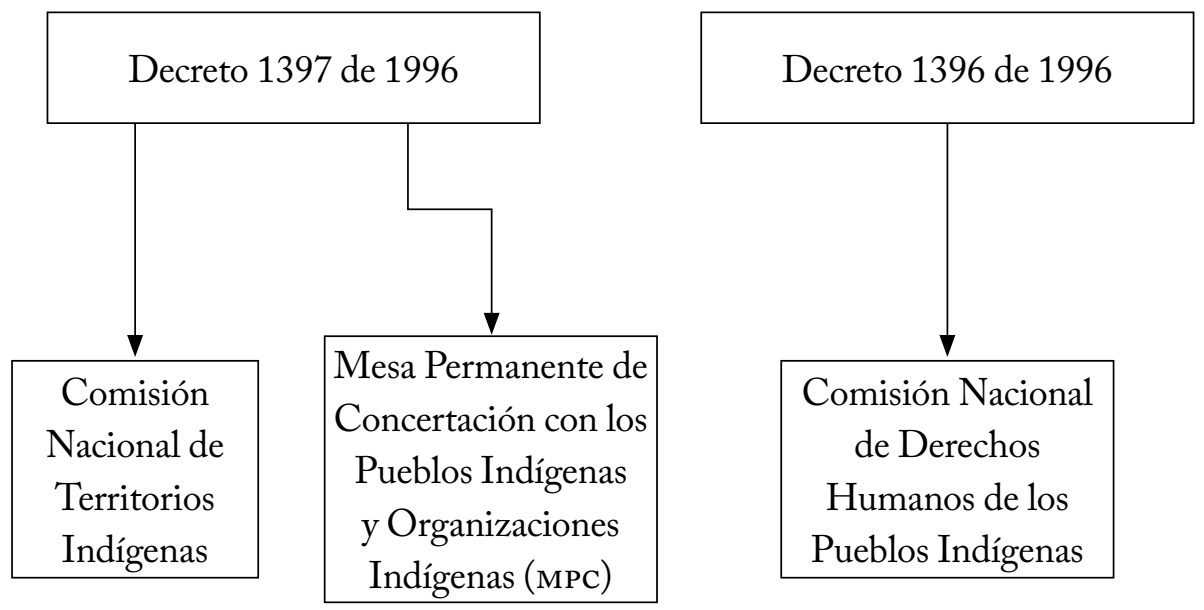

Figura 2. Escenarios de diálogo y concertación con el gobierno nacional, Decretos 1396 y 1397 de 1996

Fuente: MPC (2013,21).

\subsubsection{Mesa Permanente de Concertación (MPC)}

Mediante el Decreto 1397 de 1996 se crea la Mesa Permanente de Concertación con los pueblos y organizaciones indígenas (MPC), adscrita al Ministerio del Interior. Esta tiene por objeto concertar entre estos y el Estado todas las decisiones administrativas y legislativas susceptibles de afectarlos, evaluar la ejecución de la política indígena del Estado y hacerle seguimiento al cumplimiento de los acuerdos a que allí se lleguen. A continuación estableceremos quiénes hacen parte de la MPC: 
Tabla 8. Integrantes o actores principales de la Mesa Permanente de Concertación Nacional

\begin{tabular}{|c|c|}
\hline $\begin{array}{l}\text { Por los pueblos indígenas: } \\
\text { - La Organización Nacional Indígena de Co- } \\
\text { lombia (onic). } \\
\text { - La Organización de Pueblos Indígenas de la } \\
\text { Amazonía Colombiana (opiad). } \\
\text { - La Confederación Indígena Tayrona (cit). } \\
\text { - Cinco (5) delegados por cada macroregional. } \\
\text { - Los ex constituyentes indígenas: Alfonso } \\
\text { Peña Chepe, Lorenzo Muelas y Francisco } \\
\text { Rojas Birry. } \\
\text { - Los senadores indígenas. } \\
\text { Son invitados permanentes: } \\
\text { - Autoridades tradicionales indígenas de Co- } \\
\text { lombia - Gobierno Mayor y } \\
\text { Autoridades Indígenas de Colombia por la } \\
\text { Pacha Mama (aico). }\end{array}$ & $\begin{array}{l}\text { Por Gobierno Nacional: } \\
\text { - } \text { El Ministro del Interior o su delegado. } \\
\text { - } \text { E1 Ministro de Agricultura y Desarrollo } \\
\text { Rural o su delegado. } \\
\text { - E1 Ministro del Medio Ambiente o su } \\
\text { delegado. } \\
\text { - E1 Ministro de Hacienda y Crédito Público } \\
\text { o su delegado. } \\
\text { - E1 Ministro de Desarrollo Económico o su } \\
\text { delegado. } \\
\text { - E1 Ministro de Minas y Energía o su } \\
\text { delegado. } \\
\text { - E1 Ministro de Salud o su delegado. } \\
\text { - El Ministro de Educación Nacional o su } \\
\text { delegado. } \\
\text { Pl Director del Departamento Nacional de } \\
\text { El Consejero Presidencial de Fronteras o su } \\
\text { - El Consejero Presidencial de Política Social } \\
\text { o su delegado. }\end{array}$ \\
\hline
\end{tabular}

Fuente: MPC $(2013,22)$.

La Mesa Permanente de Concertación tiene entre sus funciones la de adoptar principios, criterios y procedimientos en relación con biodiversidad, recursos genéticos, propiedad intelectual colectiva y derechos culturales asociados a estos, en el marco de la legislación especial de los pueblos indígenas. También le corresponde concertar previamente con los pueblos y organizaciones indígenas las posiciones y propuestas oficiales para proteger los derechos indígenas en materia de acceso a recursos genéticos, biodiversidad y protección del conocimiento colectivo, innovaciones y prácticas tradicionales que presente el gobierno colombiano en instancias internacionales o en el marco de los acuerdos y convenios suscritos y ratificados por Colombia.

De igual forma, la Mesa Permanente de Concertación debe concertar el desarrollo de los derechos, la legislación ambiental y el proyecto de ley que modifica el Código de Minas, con el fin de garantizar los derechos de los pueblos indígenas; definir el cronograma, los procedimientos y los presupuestos necesarios para la delimitación de zonas mineras indígenas de acuerdo con las solicitudes de las comunidades, y hacerle seguimiento a su ejecución; revisar los permisos y licencias otorgados sobre territorios indígenas y solicitar 
su suspensión o revocatoria cuando sean violatorios de los derechos de los pueblos indígenas, de conformidad con la legislación especial; $\mathrm{y}$ concertar las partidas presupuestales que se requieran para capacitación, estudios técnicos, asesoría y financiación de proyectos con destino a las comunidades y pueblos indígenas. Este espacio de participación también debe preparar los procedimientos necesarios para acordar, entre los pueblos y organizaciones indígenas, la propuesta de reglamentación del derecho de participación y concertación de las decisiones susceptibles de afectarlos, de acuerdo con sus particularidades. En la MPC se acuerda el procedimiento transitorio y lo demás que se requiera para la participación, consulta y concertación con los pueblos o comunidades indígenas específicos, mientras se expide el decreto reglamentario, respetando los usos y costumbres de cada pueblo.

Otra de las funciones de la Mesa Permanente de Concertación es hacer seguimiento a la ejecución de la inversión social y ambiental para los pueblos indígenas dispuesta por la Ley del Plan Nacional de Desarrollo, concertar los proyectos de ley y decretos reglamentarios relativos a las transferencias de ingresos corrientes de la nación a los resguardos indígenas y hacer seguimiento al cumplimiento de los mismos. De igual forma, debe revisar las normas relativas a la educación propia, concertar sus modificaciones y reglamentación y vigilar su cumplimiento.

En la actualidad, la MPC cuenta con comisiones temáticas establecidas en el artículo 13 del Decreto 1397 de 1996 (figura 3) que tienen que ver con asuntos específicos. En ellas participan las entidades oficiales, de acuerdo con sus competencias constitucionales y legales, al igual que los delegados o delegadas de los pueblos y organizaciones indígenas directamente interesados o afectados, cuando se traten temas específicos de sus comunidades o regiones. Actualmente son siete comisiones temáticas que apoyan también el trabajo de la MPC (MPC 2013, 23). 
Mesa Permanente de Concertación Nacional con los pueblos y organizaciones indígenas

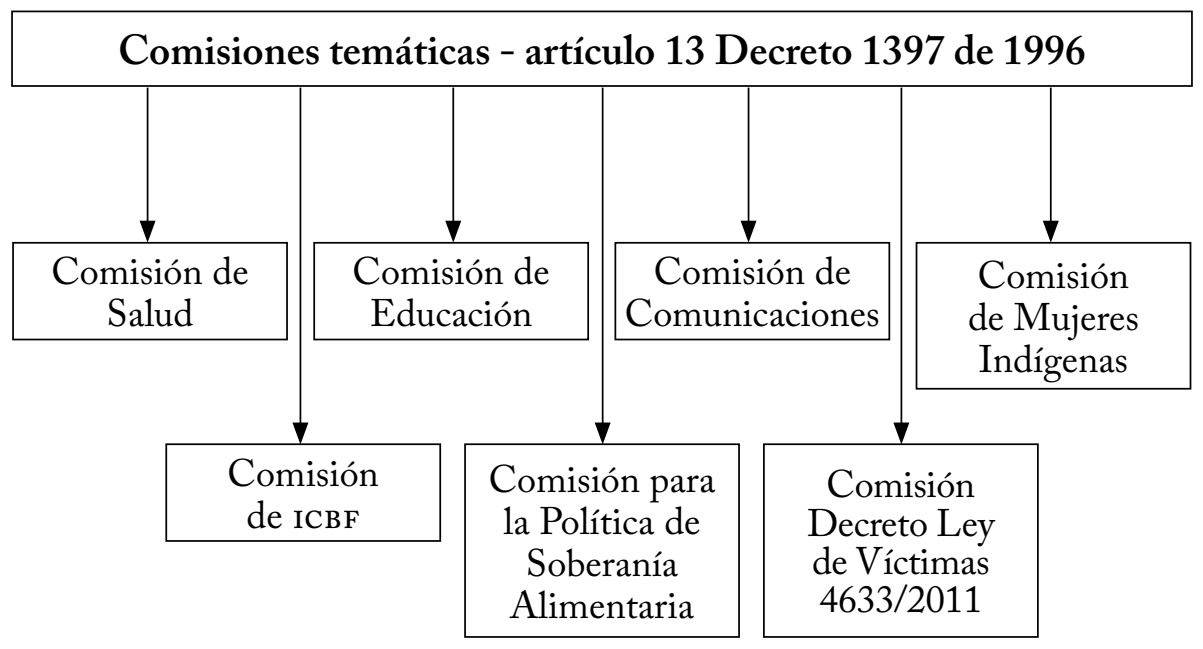

Figura 3. Comisiónes temáticas según artículo 13 del Decreto 1397 de 1996

Fuente: MPC (2013,23).

\subsubsection{Comisión Nacional de Territorios Indígenas}

Por otro lado, está la Comisión Nacional de Territorios Indígenas, también creada por el Decreto 1397 de 1996 y adscrita al Ministerio de Agricultura y Desarrollo Rural. Entre otras funciones, le corresponde acceder a la información consolidada sobre gestión del Incoder respecto a resguardos indígenas y actualizarla teniendo presentes las necesidades de las comunidades y pueblos indígenas para la constitución, ampliación, reestructuración y saneamiento de resguardos y reservas indígenas y la conversión de estas en resguardos.

Adicionalmente, debe concertar la programación para períodos anuales de las acciones de constitución, ampliación, reestructuración y saneamiento de resguardos, además de la conversión de reservas indígenas. Entre otras cosas, debe presentar al gobierno nacional la partida necesaria para la ejecución del cronograma durante el primer año para que este gestione en el Congreso de la República su inclusión en el proyecto de ley de presupuesto y bajo el criterio de la obligación del Estado de proteger la diversidad étnica y cultural de la nación y del ordenamiento de los territorios indígenas, analizar las normas de la legislación agraria atinentes a resguardos indígenas y recomendar las 
modificaciones que se requieran para superar los principales obstáculos que se presentan.

\subsubsection{Comisión de Derechos Humanos de los Pueblos Indígenas}

La Comisión de Derechos Humanos de los Pueblos Indígenas fue creada mediante el Decreto 1396 de 1996, al igual que el programa especial de atención a los indígenas. La comisión tiene entre sus funciones principales la de velar por la protección y promoción de los derechos humanos de los pueblos indígenas y de los miembros de dichos pueblos, y especialmente de sus derechos a la vida, a la integridad personal y a la libertad.

De igual forma, esta comisión debe definir medidas para prevenir las violaciones graves de los derechos humanos y propender por su aplicación y diseñar medidas tendientes a reducirlas y eliminarlas. Le corresponde también hacer seguimiento e impulsar las investigaciones penales y disciplinarias que se lleven a cabo en relación con las violaciones graves de los derechos humanos de los indígenas, con sujeción a las normas que regulan la reserva legal, y diseñar un programa especial de atención de indígenas víctimas de la violencia, sus familiares inmediatos, viudas y huérfanos, con cubrimiento nacional, y definir los mecanismos para su funcionamiento y ejecución.

\subsubsection{La participación política de los pueblos indígenas}

En Colombia se ha establecido una circunscripción especial para la elección de dos senadores por las comunidades y pueblos indígenas, la cual se rige por el sistema de cuociente electoral. Quien aspire a ser senador de la república por esta circunscripción deberá haber ejercido un cargo de autoridad tradicional en su respectiva comunidad o haber sido líder de una organización indígena. También se asegura la participación mediante circunscripción especial de representantes de los grupos étnicos en la Cámara de Representantes. ${ }^{105}$

La Corte Constitucional ha resaltado que, de manera específica, ese derecho general de participación se manifiesta, en el ámbito de las medidas legislativas que conciernan a los pueblos indígenas, y tribales, (1) en la posibilidad que sus integrantes tienen de concurrir, en igualdad de condiciones con todos los colombianos, en la elección de sus representantes en las corporaciones de elección popular; (2) en el hecho de que, en desarrollo del carácter público

${ }^{105}$ Participación política, arts. 171 y 176 de la Constitución Política. Ver: ccc, C-169/01 y C-490/11. 
del proceso legislativo, pueden conocer las iniciativas en trámite, promover discusiones, remitir conceptos y solicitar audiencias ${ }^{106}$ y (3) en las previsiones constitucionales sobre la circunscripción especial indígena, porque si bien quienes allí resulten elegidos no representan formalmente a las distintas comunidades y pueblos indígenas, sí son voceros, de manera amplia, de su particular cosmovisión y pueden constituir efectivos canales de comunicación entre las células legislativas y las autoridades representativas (C-030 de 2008).

Sobre el particular, la investigadora Laurent $(2005,455)$ asegura que a partir de la observación de los procesos electorales y de las formas de ejercicio del poder local, regional y nacional planteados por los representantes del movimiento indígena se definieron una serie de dinámicas tales como el crecimiento de su visibilidad en la sociedad, su presencia en el 'juego político' del país a pesar de su condición —-muchas veces— minoritaria y un potencial significativo de apertura hacia otros sectores de la población; pero también la insuficiencia de su preparación, la aparición de divisiones fuertes y numerosas, en algunos casos la falta de claridad entre elegidos, organizaciones y bases comunitarias y, por todas estas razones, el planteamiento de una reflexión permanente sobre los efectos de la participación electoral.

\subsection{La consulta y la participación, reiteradas demandas}

La participación señala la posibilidad de integrarse en la vida social como colectividad y como miembros de una comunidad. También como titulares de derechos y deberes que implican un ejercicio consciente y responsable, lo que abre la posibilidad de utilizar herramientas para tomar decisiones y hacer parte efectiva de las decisiones que se adopten (Rodríguez y Muñoz 2009, 22). Para la solución de las controversias, para la protección de la diversidad étnica y la defensa de los derechos ambientales, la Constitución Política de Colombia consagró la participación y abrió la posibilidad de instaurar una justicia por consenso, a través de diferentes mecanismos, garantizando los derechos de todas las personas. De esta manera, el constituyente de 1991 tuvo

${ }^{106}$ En el Capítulo ix de la Ley 5 de 1992 se regula la participación ciudadana en el estudio de los proyectos de ley, asunto en relación con el cual el artículo 230 dispone que "Para expresar sus opiniones toda persona, natural o jurídica, podrá presentar observaciones sobre cualquier proyecto de ley o de acto legislativo cuyo examen y estudio se esté adelantando en alguna de las Comisiones Constitucionales Permanentes". 
en cuenta la intervención de la colectividad, la cual termina por constituirse en un indicador de una verdadera democracia participativa. ${ }^{107}$

La consulta y la participación como derechos fundamentales buscan prevenir el abuso del poder político y económico. A través de su ejercicio, se legitiman las decisiones y se da la oportunidad para que las personas opinen y se apropien de los programas y proyectos ambientales, haciendo realidad el artículo 79 de la Carta Magna que estableció el derecho a gozar de un ambiente sano y el deber de garantizar la participación de la personas en las decisiones que puedan afectarlas.

En este mismo sentido, el legislador, mediante la Ley 99 de 1993, consagró nuevos mecanismos de participación en materia ambiental, 108 a través de los cuales se busca la prevención de los conflictos ambientales. Sobre estas premisas, consideramos que un elemento fundamental a tener en cuenta dentro de las políticas públicas de sostenibilidad es la participación, la cual se constituye en un instrumento que de manera reiterada solicitan las comunidades (esto fue evidente en los talleres efectuados) cuando se va a autorizar el uso y manejo de los recursos naturales y del ambiente o, también, cuando se van a otorgar licencias ambientales.

En los encuentros con comunidades y pueblos indígenas efectuados en el marco de este proyecto de investigación se reclamaba la real incidencia de los diferentes actores en la construcción de políticas y diferentes decisiones ambientales. Consideran, por ejemplo, que los problemas ambientales se pueden prevenir mediante la construcción participativa de una agenda ambiental que obedezca a las necesidades reales de la población colombiana y que, para ello, es necesario promover cambios políticos y sociales que abran el camino de la participación democrática de las personas y comunidades involucradas y posibiliten el fortalecimiento de su papel en la toma de decisiones.

\footnotetext{
107 A partir de 1991, la participación aparece como un principio, un derecho, un deber y un mecanismo para el ejercicio de la ciudadanía. Dicho principio está ligado al carácter pluralista del Estado, en la medida en que uno de sus fines esenciales es el de garantizar la efectividad de los mecanismos de participación de todos los asociados. En la Constitución Política, además del preámbulo, las disposiciones generales sobre participación se encuentran en los siguientes artículos: 3, 7, 20, 23, 37,38, 39, 40, 45, 49, $57,60,64,68,74,78,79.86,88,89,103,104,106,112,154,155,242,246,258,260,270,311,318,329$, $330,340,369,374,375,376,377$.

${ }^{108}$ Como la intervención en procesos administrativos, la consulta previa, las veedurías y las audiencias públicas ambientales, entre otros.
} 
Por otro lado, en los casos analizados sobre conflictos ambientales en territorios indígenas y en los talleres efectuados se planteaba como una estrategia importante para prevenir y resolver los conflictos no sólo la participación, también "la consulta previa, libre e informada".

La participación es considerada por los actores del conflicto como fundamental, porque a través de ella se puede lograr que la población conozca sus derechos y se empodere en su protección y defensa. Adicionalmente, posibilita que las colectividades se enteren de los proyectos, obras y actividades que se proponen realizar y les permite incidir de manera positiva y propositiva en los instrumentos para prevenir, mitigar o compensar los impactos que estos puedan generar cuando sean de su interés.

Los indígenas estiman que no obstante los avances jurídicos en el tema ambiental y la gran cantidad de mecanismos de participación existentes en nuestra legislación, se presentan muchas dificultades en asumir estrategias para identificar, manejar y solucionar los problemas que deben enfrentar. De esta forma, consideran que no podemos desconocer que aún en Colombia falta una cultura participativa, porque no son suficientemente conocidos y ejercidos los mecanismos de participación. A esto se debe sumar el hecho de que los dueños de los proyectos y las autoridades no han entendido aún que la deficiente información acerca de los mismos, y la intervención que implican en los territorios, vidas y culturas de las comunidades, genera dificultades y conflictos, pues estas vienen a enterarse cuando las decisiones ya han sido tomadas.

Por estas razones, los indígenas consideran que los modelos de gestión deben ser modificados para estimular el ejercicio de la participación, pues, al sentirse respaldados por la Constitución, pueden lograr la defensa de sus derechos y fortalecerse para enfrentar los problemas que se presenten en sus comunidades. Para ellos la participación es un componente que no pude faltar dentro de la construcción de la gobernabilidad y de la gestión, porque en el país se plantea la posibilidad de un accionar inclusivo y participativo.

En aras de lograr una cultura participativa, señalan que se debe promover entre las comunidades, las instituciones y el sector empresarial el reconocimiento de los espacios de participación y su ejercicio. Adicionalmente, tener en cuenta la utilización de los mecanismos propios de solución de conflictos, los cuales también deben constituirse en un sistema idóneo para resolver problemas, sobre todo, si tenemos en cuenta que en el país ha predominado la judicialización como la manera preponderante de dirimir controversias. Esta 
situación genera la necesidad de promover la aplicación de otras metodologías que se caractericen por brindar opciones nuevas sin necesidad de sentencias o fallos judiciales.

\subsection{La función simbólica de los derechos indígenas}

Más intenso es cada día el debate de los derechos de los pueblos indígenas. Eso obedece a las profundas transformaciones políticas, sociales y económicas que marcaron en mayor o menor grado a todos los países de la región latinoamericana en los años ochenta y noventa. En esas décadas se restablecieron o consolidaron, según el caso, los regímenes democráticos y cambió el paradigma de desarrollo: finalizó la estrategia de sustitución de importaciones y comenzó la apertura a la economía globalizada (Regalado Gutiérrez 2010, 61). Un recurso comunicativo básico para la democracia fue promover el diálogo intercultural junto al respeto de los derechos de los pueblos indígenas.

Conviene entonces mencionar que la Corte Constitucional colombiana, según el profesor Bonilla Maldonado (2006, 41-43), ha presentado de la manera más clara y meticulosa su interpretación de la tensión constitucional entre los valores políticos liberales y las diferencias culturales. Mediante las sentencias analizadas anteriormente, este tribunal intenta, sin conseguirlo desafortunadamente, solucionar dicha tensión. Tienden a complicarse las reglas que guían las relaciones entre los pueblos indígenas y la mayoría de la población del país, en especial, en los casos relacionados con los proyectos y la explotación de recursos naturales en los territorios indígenas en los que es obligatorio adelantar la consulta previa. En ellos es mucho más evidente esa tensión entre unidad y diversidad cultural que existe en la Carta Política.

\subsubsection{Entre la enunciación y el ejercicio de los derechos}

Los pueblos indígenas son titulares de derechos fundamentales como el derecho a la integridad étnica y cultural, que contiene otros: a la supervivencia cultural, a la preservación de su hábitat natural, a la propiedad colectiva sobre la tierra habitada por la comunidad, a determinar sus propias instituciones jurídicas, a administrar justicia en su territorio y a regirse por sus propias normas y procedimientos, a determinarse por su cosmovisión religiosa y a hacerla valer ante terceros, a participar en la toma de decisiones que puedan afectarlos $\mathrm{y}$ al derecho de acudir a la justicia como comunidad (ccc, T-778/05). Ese es 
el panorama que ayudan a develar nuestro estudio y el examen que hace del desarrollo jurisprudencial de la Corte Constitucional.

Sin embargo, también son notorias las dificultades en la aplicación de esos derechos. El 'constitucionalismo multicultural', del que se espera el reconocimiento de la presencia de los pueblos o comunidades indígenas, adolece de falta de rigor y aseguramiento normativo, por lo que no pueden hacer efectivos los derechos. Sus postulados dependen casi integralmente de una posterior creación normativa de instituciones estatales de orden monocultural, como lo asegura el profesor Aparicio Wilhelmi $(2011,10)$. Aparicio agrega que no existen, en consecuencia, auténticos derechos constitucionales colectivos, porque estos se ven supeditados al respeto de un determinado marco jurídico que, dada la estructura socio-política existente, responde a los principios de una única cultura, la cultura dominante.

Muchos de estos problemas radican en la contraposición de intereses y al hecho que algunos sectores de la sociedad le restan importancia y consideran que las expectativas de los pueblos indígenas son un obstáculo para el desarrollo del país. A esto debe sumarse que, en los casos objeto de nuestro estudio, su garantía requiere no sólo de una experticia en cuanto a las normas sobre los grupos étnicos, sino también en relación con los derechos sociales, culturales, ambientales y económicos, entre otros.

Sin desconocer los avances de la Constitución promulgada en 1991, los derechos son insuficientes en materia de protección de la diversidad étnica y cultural de la nación colombiana. ${ }^{109}$ Empero, creemos que se pueden lograr mejores resultados si se efectúan acciones que permitan el fortalecimiento organizativo y el respeto de dichos derechos. Eso va ligado también al seguimiento que deben hacer las entidades encargadas y los estudiosos del tema al curso que sigue la aplicación de las normas sobre los pueblos indígenas.

Por ejemplo, los tribunales encargados de dirimir disputas de tierras entre terratenientes o empresas, por una parte, y pueblos indígenas y campesinas

\footnotetext{
${ }^{109}$ Aunque se reconocen estos derechos e incluso se realizan avances legislativos y jurídicos significativos con relación a su protección, los pueblos indígenas no consiguen su ejercicio efectivo y sufren fuertemente, porque a pesar de tener reconocidos y titulados sus resguardos, estos se ven invadidos por los actores del conflicto armado, los terratenientes y colonos y por las empresas trasnacionales que llegan con suculentos contratos de explotación de recursos naturales. En este contexto, el caso colombiano nos sitúa frente a los mismos límites del derecho y nos obliga a reflexionar con urgencia sobre su aplicabilidad y utilidad (Berraondo López 2011, 298).
} 
pobres, por otra, tienden a proferir fallos basados únicamente en las normas jurídicas que protegen las inversiones y la propiedad privada. Del mismo modo, es frecuente que los tribunales no ponderen los derechos humanos y las normas que aseguran la propiedad en casos en los que se impugna la legalidad de las reglamentaciones de los programas de redistribución de tierras - especialmente las reglamentaciones relacionadas con expropiación de tierras, extinción de dominio y confiscación de terrenos apropiados de manera fraudulenta (Ariza Santamaría 2010b, 87).

Dicho de otra manera, es preciso reconocer que las reivindicaciones de esos pueblos tienen que ir más allá del reconocimiento y respeto de sus derechos legalmente establecidos: deben abarcar también lo económico y lo político. El problema étnico debe considerarse concretamente como un asunto de índole social, económica y política y concebirse como una solución social. Sus realizadores deben ser los propios pueblos indios, para que de esta forma sean ellos quienes decidan su rumbo histórico (Mariátegui 2007,24).

En este punto, es pertinente concluir dos asuntos: en el ejercicio de sus derechos, los pueblos indígenas deben estar libres de toda forma de discriminación (onu 2007a) y aunque la Corte Constitucional ha considerado fundamentales muchos de esos derechos, estos se refieren en especial a un sujeto de derecho de carácter colectivo que posee formas diferentes de vida social de la que llevan los sujetos individuales.

Con respecto a la segunda conclusión, los argumentos mencionados de la Corte Constitucional aluden a que los intereses dignos de tutela constitucional y amparables bajo la forma de derechos fundamentales no se reducen a los predicables de sus miembros individualmente considerados: también logran radicarse en la comunidad misma que, como tal, aparece dotada de singularidad propia, la que es justamente el presupuesto del reconocimiento expreso que la Constitución hace a la diversidad étnica y cultural de la nación colombiana.

La protección que la Carta Política extiende a la anotada diversidad cultural se deriva, adicionalmente, de la aceptación constitucional de formas diferentes de vida social, cuyas manifestaciones y permanente reproducción cultural son imputables a estas comunidades o pueblos como sujetos colectivos autónomos y no como simples agregados de sus miembros (precisamente, cada miembro se realiza en el grupo). A la vez, la Constitución asimila como suya la unidad de sentido que surge de las distintas vivencias comunitarias. 
En consecuencia, establece la Corte Constitucional (T-308/93) que el reconocimiento exclusivo de derechos fundamentales al individuo, con prescindencia de concepciones diferentes como aquella que no admite una perspectiva individualista de la persona humana, es contrario a los principios constitucionales de democracia, pluralismo, respeto a la diversidad étnica y cultural y protección de la riqueza cultural.

En este marco, es necesario reafirmar que los derechos de los pueblos indígenas hacen parte del bloque de constitucionalidad. No obstante, es preciso reflexionar sobre lo que ha acontecido con la efectivización de dichos derechos. Los pueblos indígenas hacen evidente sobre el particular que aunque existen unos reconocimientos constitucionales y legales a su cultura en el ordenamiento jurídico colombiano, se trata sólo de buenos propósitos retóricos por parte del Estado (onic 2007a, 9) y ponen de presente los problemas de violencia, desplazamiento, pobreza, usurpación de sus recursos naturales y violación al derecho a la autonomía.

En ese mismo sentido, el informe del ex relator Rodolfo Stavenhagen (2004) señala que la brecha existente entre la constitucionalidad, la efectiva aplicación de las normas y la funcionalidad institucional hace que los adelantos de la Constitución se vean limitados. Destaca que en el transcurso de los últimos años se han producido avances, pero que todavía existen grandes retos que debe enfrentar la nación en la protección y promoción efectiva de los derechos humanos y libertades fundamentales de los indígenas.

De igual forma, es necesario mencionar que los organismos de control de la OIT han enfatizado que la clave para superar la desigualdad de larga data y profundamente arraigada que afecta a los pueblos indígenas es la acción coordinada y sistemática orientada a garantizar estos derechos. Este es un mensaje crítico, pues los derechos de estas colectividades a menudo se interpretan mal en el sentido de que otorgan privilegios y ventajas a los pueblos indígenas que no otorgan a otros sectores de la sociedad. Por el contrario, el reconocimiento de los derechos es un prerrequisito para que estos puedan participar y beneficiarse en pie de igualdad con la sociedad nacional y constituye un instrumento para eliminar su discriminación (oit 2009,30).

En los casos en que los pueblos indígenas estén en una relación de desventaja, como la que se presenta en nuestro país debido a la falta de reconocimiento y protección de sus derechos, como también de las desigualdades generadas a través de los procesos históricos de discriminación y marginación, 
es posible que se necesiten medidas especiales para superar esta situación, en cuyo caso deben adoptarse disposiciones relacionadas con las tierras y territorios, el ambiente y los recursos naturales, el empleo, la salud, la educación, etc. En lugar de recurrir a derechos o privilegios adicionales, las medidas especiales buscan proteger las instituciones, los bienes, el trabajo, la cultura y el ambiente de los pueblos indígenas, puesto que su último objetivo es garantizar que estos pueblos disfruten de todos los derechos humanos, sin que en ningún momento puedan ser consideradas como discriminatorias en cuanto al resto de la población que no es indígena (oit 2009, 35).

Evidentemente se han presentado problemas con el ejercicio de los derechos mencionados. Incluso, la propia Corte Constitucional (Auto 004/09) señaló que algunos pueblos indígenas de Colombia están en peligro de exterminio - cultural y/o físico - por el conflicto armado interno y han sido víctimas de gravísimas violaciones de sus derechos fundamentales individuales y colectivos y del derecho internacional humanitario. Es más, en el reciente informe anual del alto comisionado de las Naciones Unidas para los derechos humanos en Colombia se asegura que queda mucho por hacer para lograr su reconocimiento en la práctica, aunque el respeto de la autonomía, la propiedad, el control territorial y el autogobierno, además de cuestiones relativas a la consulta previa, la salud, la educación y las comunicaciones, está reconocido por el derecho nacional e internacional y ha sido objeto de clarificaciones detalladas en la jurisprudencia de la Corte Constitucional. Por ello, alienta a todos los interesados a seguir esforzándose para mejorar el respeto de los derechos de los indígenas y de las personas más afectadas por el conflicto armado (onu 2013, 19).

\subsubsection{Examen de la institucionalidad}

Es imposible decir con certeza que el país cuenta con una política pública para las colectividades en mención, aunque la Constitución Política haya redefinido la cuestión indígena como un asunto de orden nacional que trasciende del marco agrario o del sector rural y sea parte de la reorganización y modernización del Estado en tanto parte constitutiva esencial de la nación. Es necesario avanzar en la construcción de esquemas de participación que respeten la autonomía, la identidad y las formas propias de reproducción social y en general los derechos humanos colectivos e individuales (DGAI - Colombia, Ministerio del Interior 1998,21). La Corte Constitucional ha tratado de suplir de manera 
parcial y fragmentada esta situación con sus pronunciamientos y en especial mediante el Auto 004 de 2009, que sienta elementos para la construcción de esa política que requieren los pueblos indígenas.

Es más, apenas comienza la discusión entre el gobierno y los pueblos indígenas sobre una política pública que permita desarrollar y aplicar los derechos consagrados. A propósito de la formulación del Plan Nacional de Desarrollo 2010-2014 "Prosperidad para todos", el gobierno nacional se comprometió a adoptar una política pública nacional para la promoción y el fomento de condiciones que permitan la igualdad de oportunidades; el ejercicio pleno de las garantías de los derechos humanos integrales e interdependientes; la participación en la vida política, cultural, económica y social, teniendo en cuenta las particularidades que afectan a los grupos indígenas y, para el efecto, deben concurrir de manera corresponsable la nación, las entidades territoriales y la sociedad civil, de conformidad con la Constitución Política y la ley. Pero sin una verdadera voluntad política, no es posible adoptar de manera conjunta una política pública como la planteada, que cuente con recursos suficientes para su implementación y así hacer realidad los derechos de los pueblos indígenas.

Con el fin de establecer lo que está sucediendo se requiere determinar el estado de la institucionalidad colombiana con respecto a los pueblos indígenas. Sirven de base para ello los planteamientos de la profesora Yrigoyen Fajardo (2010, 43-44) sobre América Latina. A lo largo de estos años se ha evidenciado un marcado énfasis en la consagración de normas sobre pueblos indígenas, pero a la vez se presenta una carencia de políticas y fortalecimiento institucional para la gestión de las mismas en las instancias estatales tanto del orden nacional como regional y local, que posibiliten hacer efectivos los derechos. Ha sido insuficiente la existencia de aparatos institucionales dotados de recursos humanos y materiales, incluidos presupuestos, personal formado, etc. (Yrigoyen Fajardo 2010, 43).

Podríamos decir que en Colombia, aunque efectivamente diversas instituciones tienen entre sus competencias asuntos relacionados con los pueblos indígenas, son limitados los recursos y el personal asignado para realizar su trabajo. Debemos reconocer que se carece de modelos e instrumentos de gestión como manuales, en los cuales los perfiles de los funcionarios y los términos de referencia indiquen quién y cómo debe ejercer las funciones públicas, de tal modo que se apliquen y respeten los derechos indígenas y se 
brinden los servicios públicos con pertinencia lingüística, cultural y de género. Estos instrumentos de gestión serían de gran valor, en especial para los funcionarios locales y regionales que no tienen muy claros los derechos ni sus funciones al respecto.

Una política pública clara en materia de derechos y pueblos indígenas permite superar las asimetrías y diversidad de visiones que se presentan en Colombia en cuanto al desarrollo, que evidencia las posturas contrarias entre las mismas instituciones, por ejemplo, en lo referente a proyectos extractivistas: el Ministerio de Minas y el Ministerio de Ambiente cuentan con posiciones diferentes en relación con el uso de los recursos y los derechos de los pueblos indígenas.

Es fundamental superar las dificultades y trabajar para evitar que los casos de vulneración de los derechos terminen judicializándose como única alternativa de solución. Sin embargo, es preciso mencionar que si esto último sucede, los operadores jurídicos (jueces y magistrados) tienen nuevas perspectivas en su tarea de legitimación y protección de los derechos desde un sentido garantista (García Lozano 2010,138).

En el orden nacional existen espacios institucionalizados de diálogo, consulta y participación indígena como la Mesa Permanente de Concertación. Sin embargo, en el orden local y regional se requiere que las instituciones incentiven la creación de mecanismos similares que posibiliten la descentralización, para promover acercamientos y diálogos fluidos que permitan lograr acuerdos y adoptar políticas.

Así las cosas, es importante fortalecer los mecanismos de control y transparencia para el efectivo cumplimiento de los derechos indígenas. En este contexto, consideramos pertinente el cumplimiento de las funciones de los órganos de control como la Procuraduría General de la Nación y la Defensoría del Pueblo, los cuales, en el marco de los talleres, fueron cuestionados por los pueblos indígenas, quienes plantearon las tímidas actuaciones de dichas instituciones en los conflictos planteados. ${ }^{110}$

Este panorama nos lleva a considerar que es necesario establecer mecanismos de prevención y de manejo de los conflictos, en los cuales se requiere la participación real y efectiva de los pueblos indígenas, donde además existan

\footnotetext{
${ }^{110}$ No obstante lo anterior, es pertinente señalar que los indígenas destacaron la labor realizada en los últimos años por el Dr. Horacio Guerrero, ex funcionario de la Defensoría del Pueblo.
} 
funcionarios capacitados y dispuestos a trabajar en pos del ejercicio efectivo de los derechos de estos pueblos.

Recogiendo estos planteamientos, consideramos que de esta manera, tomando en cuenta las visiones y expectativas de los pueblos indígenas y demás sectores de la población, es posible superar los obstáculos que se presentan y que han dificultado el ejercicio efectivo de los derechos que terminan por cumplir una función simbólica. 


\section{Conclusiones}

Con sus demandas, los pueblos indígenas han logrado, a través de los años, el reconocimiento de su aporte al desarrollo de Colombia y de sus derechos como grupos diferenciados, los cuales cuentan con culturas que representan el patrimonio de nuestro país. Ellos reclaman prioritariamente la garantía del derecho al territorio que consideran fundamental para la pervivencia de sus culturas, de sus formas organizativas y para el ejercicio del derecho propio.

La consagración de los derechos de estas colectividades ha sido el resultado de la lucha política y la negociación que durante mucho tiempo han dado los pueblos indígenas ante el despojo de sus tierras, el deterioro de sus culturas y la discriminación que han debido afrontar. Es necesario entonces tener presente que principios como la dignidad humana y el pluralismo inspiraron al Constituyente de 1991 para reconocer no sólo la importancia de proteger la diversidad étnica y cultural de la nación colombiana, sino para asignar un estatus especial a los pueblos indígenas que hoy son titulares del derecho al territorio, a la autonomía, a la jurisdicción especial y a la participación, entre otros.

Los mandatos constitucionales, en conjunto con el Convenio 169 de la OIT, la DNUPI y una amplia jurisprudencia emanada de la Corte Constitucional y de la Corte Interamericana han establecido, con respecto a esos derechos, mecanismos a través de los cuales se busca proteger esa diversidad cultural existente en nuestro país.

Es así como los derechos de los pueblos indígenas comprenden prerrogativas - en el orden político, la defensa de los territorios y los recursos naturales existentes- que se dan en ejercicio de su autonomía y libre determinación, es decir, de la libre elección del estatuto social y político que les compromete. El derecho a la autonomía abarca, entre otras cosas, el derecho a elegir sus sistemas de gobierno, sus gobernantes o autoridades de acuerdo con sus usos y sus costumbres, y con sus formas de ejercer justicia. Así mismo, la autonomía se ejerce a través de las organizaciones y formas sociales, culturales, políticas y económicas que poseen los pueblos indígenas. 
En sentido amplio, la garantía del derecho a la autonomía implica el respeto de sus formas tradicionales de vida, de gobierno, de control social, de uso y manejo de sus recursos naturales y del territorio, por lo cual, la adopción de cualquier decisión que pueda afectar los pueblos indígenas debe ser previamente concertada con ellos, dando cumplimiento a los derechos de participación y consulta. De esta forma, se hacen efectivos los postulados constitucionales y legales, siendo posible garantizar su integridad cultural, social y económica.

También el derecho a la jurisdicción especial indígena, los derechos religiosos y las formas organizativas que poseen estas comunidades son una manifestación de su derecho a la libertad y a la autodeterminación, así como a sus propias visiones y formas de desarrollo que hacen referencia al derecho a la integridad y a la cultura que incluye, a su vez, las lenguas y la educación propias de estas colectividades.

En este contexto, es pertinente, para garantizar los derechos y evitar las confrontaciones que se vienen presentando con los pueblos indígenas, tener en cuenta los usos, costumbres y formas propias de resolver conflictos que ellos poseen, donde se presentan estructuras institucionales que responden a sus tradiciones y formas de gobierno propias. En ejercicio de la jurisdicción especial indígena, estos pueblos pueden ejercer justicia al interior de sus comunidades, con sus normas y procedimientos, teniendo en cuenta los preceptos constitucionales y legales.

El derecho fundamental a la participación que incumbe a todos los miembros de la sociedad se constituye en un instrumento para incidir en aquellas decisiones que pueden afectarlos. Es además, un instrumento para garantizar la igualdad y superar la discriminación y la exclusión, elementos presentes en el caso de los pueblos indígenas. La participación real y efectiva en las decisiones administrativas en los proyectos de desarrollo, en las políticas sobre educación y salud, en los estudios de impacto ambiental y en la administración de áreas protegidas, se ha constituido en un reclamo constante de los pueblos indígenas.

La participación juega un papel preponderante en la gestión gubernamental, que debe hacerse realidad y que tiene que ver con las decisiones que se toman en territorios indígenas. En un Estado Social de Derecho, democrático, participativo, multicultural y pluralista, la vulneración de los derechos a la participación y a la información son un detonante de conflictos con estas colectividades. ${ }^{111}$

111 Aunque no se desarrollan en este trabajo, aparecen otros derechos cuyo estudio consideramos pertinente realizar en otra investigación, como el derecho a los recursos originarios (tangibles e 
La importancia de la participación en los procesos de adopción de decisiones radica en el hecho de ser considerada como una forma para garantizar los derechos y promover la defensa de lo público. La incorporación de la participación en la teoría y en la práctica se convierte en un gran reto para la gestión que permitiría su potencialidad en el tiempo y la prevención de futuras confrontaciones o conflictos.

Bajo este panorama consideramos que, con el fin de mejorar la gestión institucional, es necesario fortalecer la participación social y estimular a las organizaciones, comunidades y pueblos indígenas para que incidan de manera activa en la toma de decisiones, objetivo para el cual se requieren procesos de capacitación y divulgación ${ }^{112}$ oportunos de los proyectos y de las decisiones que pretendan adoptarse.

Lo que no se ha entendido hasta ahora es que, además de justificar al Estado como garante de los derechos de las personas, de las colectividades y, en especial, de los pueblos indígenas, la participación democrática en $\mathrm{Co}^{-}$ lombia es un elemento integral del desarrollo. Eso ha generado los reclamos y conflictos planteados. El Estado y la sociedad deben actuar en forma conjunta para construir un escenario de convivencia que conjugue los intereses y necesidades presentes en la esfera de lo público y de lo privado. Esto explica la posibilidad que debe ofrecerse para que los diversos actores incidan en los procesos de planeación y decisión, teniendo en cuenta que los individuos, las comunidades y los pueblos no sólo son objetos de los procesos de desarrollo, sino que son los protagonistas de los mismos.

Adicionalmente, la participación aparece como un principio, un derecho y un deber, pero encontramos que en todas sus dimensiones, esta ha sido inobservada de manera reiterativa en los casos de conflictos ambientales analizados. Por todo lo anterior, creemos que la participación es parámetro

intangibles) que comprenden además el derecho a la propiedad intelectual de los productos de la propia cultura. En otros países los pueblos indígenas vienen discutiendo temas como los derechos al desarrollo social que comprende la soberanía alimentaria y nutricional; la farmacología, artes y artesanías; derecho a una cuota fiscal compensatoria, etc.

$112 \mathrm{El}$ derecho de acceso a la información no radica únicamente en la obligación de dar respuesta a las peticiones de la sociedad, sino también en el deber de los sujetos de promover y generar una cultura de transparencia, lo que lleva la obligación de publicar y divulgar documentos y archivos que plasman la actividad estatal y de interés público, de forma rutinaria y proactiva, actualizada, accesible y comprensible, atendiendo a límites razonables del talento humano y recursos físicos y financieros (Ley 1712 de 2014). 
de constitucionalidad en la gestión del país y un principio ligado al carácter pluralista del Estado, en la medida en que uno de sus fines esenciales es el de garantizar la efectividad de los mecanismos de incidencia de todos los asociados y, de manera especial, de los pueblos indígenas que tradicionalmente han sido discriminados.

Debemos resaltar que la participación en Colombia ha llegado a ser un derecho ampliamente desarrollado en la doctrina y en la norma, pero no en su real ejercicio, por lo cual es preciso señalar que se deben propiciar más espacios para incidir en las decisiones que puedan afectar a las comunidades y a los pueblos indígenas y que es indispensable promover una gestión participativa para superar su idílica consagración normativa y los obstáculos para su realización.

En consecuencia, consideramos que la participación y la información se deben caracterizar por ser oportunas y convenientes. Deben darse antes de la toma de la decisión y ser procesos permanentes. Su efectividad se evidencia al momento de tomar la decisión final, pues tienen que valorarse los conocimientos tradicionales, las sugerencias, aportes, comentarios y críticas que sobre los proyectos manifiestan las comunidades y pueblos indígenas, lo cual constituiría un verdadero diálogo. Adicionalmente, la participación debe caracterizarse por ser preventiva y propositiva. Esto permite que de manera anticipada se evite la generación de conflictos y se tenga presente de antemano un conocimiento sobre los proyectos y los posibles impactos o afectaciones de los mismos, pues sólo ello posibilita la toma de decisiones conjuntas que permitan su adecuado manejo. Por ende, todo proceso de participación debe incluir a la totalidad de los miembros de las colectividades y no solamente a sus representantes.

No obstante la importancia de los mecanismos de incidencia, es preciso recordar que el proceso de participación, como muchos otros procesos sociales, presenta algunas dificultades en su ejercicio. Esas dificultades se pudieron observar en los talleres efectuados con los pueblos indígenas, a saber: carencia de recursos económicos y de tiempo, desconfianza en las instituciones, falta de voluntad política para implementarlos y de compromiso de los participantes o, como se ha mencionado, conflictos en el acceso a la información necesaria. ${ }^{113}$ La propuesta de los indígenas es superar estas problemáticas de manera

${ }^{113}$ Es importante mencionar que recientemente fue expedida la Ley 1712 de 2014, por medio de la cual se crea la ley de transparencia y del derecho de acceso a la información pública nacional, donde 
conjunta y trabajar en una meta que conlleve a la realización de aspiraciones que recojan sus expectativas y las necesidades de todo el país.

Las acciones colectivas de los pueblos indígenas han consolidado estrategias para consagrar y defender sus derechos. Lo anterior se evidencia en las tendencias mundiales recientes hacia el reconocimiento como una forma para superar la discriminación que han sufrido desde hace largo tiempo. Sin embargo, debemos tener en cuenta que estos derechos presentan dificultades en su implementación.

En estas circunstancias, se manifiestan confrontaciones entre la efectiva aplicación y la consagración de dichos derechos. Los pueblos indígenas claman por el respeto de sus derechos políticos, sociales, económicos y culturales, demandando judicialmente al Estado colombiano por el incumplimiento de los diferentes instrumentos normativos internos y del derecho internacional que los cobijan.

Por otra parte, si bien es cierto se han consagrado los derechos a la participación y a la consulta previa que se constituyen en la actualidad en la piedra angular del Convenio 169 de la OIT, consideramos que se debe avanzar en su efectivización teniendo presente su concordancia con el derecho al territorio, al igual que al fortalecimiento de sus organizaciones políticas, el respeto de las autoridades propias y el uso tradicional de los recursos naturales que poseen.

En dicho escenario, en primer lugar, en relación con el marco de solución de los conflictos en territorios indígenas, es necesario contar con mecanismos para hacer efectiva la tenencia y el derecho al territorio, mediante procesos de titulación que posibiliten el control de sus tierras y recursos de los cuales dependen. En segundo lugar, concluimos que en cualquier decisión (administrativa o legislativa) o proyecto que pueda afectarles directamente, es indispensable adelantar previamente la consulta para garantizar este derecho fundamental y los demás derechos relacionados. Cualquier iniciativa de desarrollo debe contar con los estudios previos sobre los impactos y con los estudios sociales y culturales que permitan valorar las afectaciones y, en igual sentido, debe incluir las manifestaciones de los pueblos indígenas. Es decir, se debe aplicar el principio de prevención y precaución cultural que venimos

se regula dicho acceso, los procedimientos para el ejercicio y garantías además de las excepciones a la publicidad. 
planteando, para evitar daños irremediables, afectación de la integridad y, en consecuencia, pérdidas de nuestro patrimonio.

El discurso de los derechos de los pueblos indígenas se constituye ahora en un tema importante de análisis, en especial porque estos han sido vulnerados y hoy es una exigencia de carácter permanente. Así, el Estado colombiano debe ser garante de los derechos de todos los colombianos y, sobre todo, de los sectores más vulnerables que, como en el caso de los pueblos indígenas, se han visto afectados por el conflicto armado y por los intereses de actores externos en controlar sus territorios y los recursos naturales que hay en ellos. Resulta entonces primordial que existan instrumentos efectivos de protección, garantía de sus derechos y mecanismos suficientes para realizar consultas previas adecuadas con estos pueblos.

Es trascendental tener en cuenta con respecto a los derechos étnicos que el principio de progresividad obliga al Estado colombiano a no tomar medidas que resulten regresivas, esto es, medidas que constituyan una interupción del avance en la ampliación de los niveles de satisfacción, y mucho menos medidas que signifiquen un retroceso injustificado en términos de la protección de los derechos fundamentales y con respecto a los niveles de satisfacción ya alcanzados. Dichas decisiones no son únicamente de tipo económico, se refieren también a cualquier disposición, política, programa o medida específica de derecho interno que tenga que ver con los contenidos prestacionales del derecho.

Así las cosas, las obligaciones de realización de los derechos y de respeto del principio de progresividad exigen al Estado la obtención de las condiciones materiales necesarias para hacerlos posibles, en el contexto de sus posibilidades. Este principio establece que tales medidas se adopten de manera que, constante y consistentemente, promuevan la plena efectividad de los derechos. Ello ha sido ampliamente desarrollado en los instrumentos internacionales relativos a los derechos económicos, sociales y culturales en la Convención Americana de Derechos Humanos y en el Pacto Internacional de Derechos Económicos, Sociales y Culturales. ${ }^{114}$

${ }^{114} \mathrm{La}$ Convención Americana de Derechos Humanos, en el artículo 26, requiere que los Estados Partes adopten "providencias, tanto a nivel interno como mediante la cooperación internacional para lograr progresivamente, por vía legislativa u otros medios apropiados, la plena efectividad" de tales derechos. Los derechos programáticos se enmarcan en el Pacto Internacional de Derechos Económicos, 
Como puede deducirse del análisis anterior, tanto la normatividad interna como la del ámbito internacional requieren procesos de integración y coordinación, teniendo presente que para los pueblos indígenas el derecho al territorio contribuye a fortalecer la identidad étnica y cultural, a proteger el patrimonio cultural y a consolidar el derecho a la autonomía. Ante la situación y la realidad que viven los pueblos indígenas, la defensa territorial es fundamental para su pervivencia como culturas.

Las constantes acciones y demandas realizadas por los pueblos indígenas clamando por el respeto de sus derechos representan su esperanza por forjar un futuro que permita la pervivencia de sus culturas, el bienestar de su pueblo y el pleno goce de sus derechos humanos. En este contexto, es necesario superar las dificultades que han dado lugar a los pronunciamientos de la Corte Constitucional, como el conflicto, el desplazamiento y la realización de proyectos inconsultos y sin participación en sus territorios, para que los pueblos indígenas puedan disfrutar, usar, disponer y gozar autónomamente de sus derechos territoriales. Para ello, es importante contar con una política pública clara, mediante la cual se hagan efectivos dichos derechos.

Aunque la Constitución Política de 1991 y el Convenio 169 contienen el reconocimiento de la diversidad étnica y cultural de la nación colombiana, el Estado debe consagrar medidas efectivas para garantizar su participación y protección de los derechos de los pueblos indígenas, acordes con sus tradiciones y culturas. Las condiciones políticas y sociales, así como el desarrollo social, cultural y económico con identidad como ellos lo plantean, deben constituirse en determinantes para superar la discriminación y efectivizar los derechos de estas colectividades. Para lograrlo, es indispensable garantizar el ejercicio y control de sus territorios y recursos además de la participación y la consulta previa en las decisiones del orden nacional, regional o local que pueden afectarles.

E1 Estado colombiano debe asumir y hacer realidad su responsabilidad de desarrollar, con la contribución de los pueblos indígenas, una acción coordinada y sistemática con miras a proteger sus derechos y garantizar el respeto de su integridad. De igual forma, debe iniciar acciones que aseguren la plena efectividad de los derechos sociales, económicos y culturales de estos pueblos,

Sociales y Culturales, en el Protocolo de San Salvador adicional a la Convención Americana que consagra dicho principio en su artículo $1^{\circ}$. 
respetando su identidad, sus costumbres, tradicionales y sus instituciones, para prevenir todo tipo de conflictos.

En conclusión, la escalada actual que se presenta en Colombia de los conflictos exige una respuesta urgente, eficaz y coordinada, con políticas y controles que se traduzcan en el respeto de los derechos de los pueblos indígenas. La garantía de los derechos previene y soluciona conflictos y, en consecuencia, se constituye en un importante factor de la construcción de la paz en Colombia. 


\section{Referencias bibliográficas}

Anaya, James. Los pueblos indígenas en el derecho internacional. Madrid: Editorial Trotta, Universidad Internacional de Andalucía, 2005.

Anaya,James. "Informe del relator especial sobre la situación de los derechos humanos y libertades fundamentales de los indígenas, 11 de agosto de 2008. Promoción y protección de todos los derechos humanos, civiles, políticos, económicos, sociales y culturales, incluido el derecho al desarrollo. Fragmento". En La Declaración sobre los derechos de los pueblos indígenas. Punto y seguido, coordinado por Mikel Berraondo López, 21-32. Barcelona: A1ternativa Intercambio con Pueblos Indígenas.

Anaya, James. "El deber estatal de consulta a los pueblos indígenas dentro del derecho internacional". Seminario sobre la consulta previa a los pueblos indígenas y el rol de los Ombudsman en América Latina, Lima, abril 25, 2013. Consultado marzo 20, 2013. http://www.politicaspublicas.net/panel/re/docs/1660-deber-de-consulta-previa.html.

Aparicio Wilhelmi, Marco. "Pueblos indígenas y constitucionalismo: de la igualdad multicultural al diálogo entre iguales". En Los derechos de los pueblos indigenas a los recursos naturales y al territorio. Confictos y desafíos en América Latina, editado por Marco Aparicio Wilhelmi, 7-30. Barcelona: Icaro Editorial S.A., 2011.

Arango Ochoa, Raúl y Enrique Sánchez Gutiérrez. Los pueblos indígenas de Colombia en el umbral del nuevo milenio. Bogotá: DNP, 2004.

Archila Neira, Mauricio. "El legado político del movimiento indígena caucano". En La voluntad indómita: fundamentos teóricos de la acción colectiva, editado por Roddy Brett y Freddy Cante, 325-365. Bogotá: Universidad del Rosario, 2012.

Archila Neira, Mauricio y Nidia Catherine González. Movimiento indígena caucano: historia y política. Tunja: Sello Editorial Universidad Santo Tomás, 2010. 
Ariza, Libardo José. Derecho, saber e identidad indígena, 1. a ed. Bogotá: Siglo del Hombre Editores, Universidad de los Andes, Pontificia Universidad Javeriana, 2009.

Ariza Santamaría, Rosembert. "Los derechos humanos en América Latina: una promesa sin cumplir”. Diálogo Politico, publicación trimestral de la KonradAdenauer-Stiftung A. C. (2010a): 73-90.

Ariza Santamaría, Rosembert. El derecho profano. Justicia indígena, justicia informal y otras maneras de realizar lo justo. Bogotá: Universidad Externado de Colombia, Facultad de Derecho, 2010b.

Ariza Santamaría, Rosembert. "Consulta previa. Dilemas del ejercicio de un derecho". En Minería, territorio y conficto en Colombia, editado por Catalina Toro Pérez, Julio Fierro Morales, Sergio Coronado Delgado y Tatiana Roa Avendaño, 283-302. Bogotá: Universidad Nacional de Colombia. Facultad de Derecho, Ciencias Políticas y Sociales. Instituto Unidad de Investigaciones Jurídico-Sociales Gerardo Molina (Unijus), 2012.

Benavides Vanegas, Farid Samir. Movimientos indígenas y luchas por derechos en Colombia. Vol. III. Movimiento Social y Teoría Poscolonial. Bogotá: Grupo Editorial Ibáñez, 2013.

Berraondo López, Mikel. “Territorios indígenas colombianos. Una historia de expolio, desplazamiento y extinción”. En Los derechos de los pueblos indigenas a los recursos naturales y al territorio. Conflictos y desafíos en América Latina, editado por Marco Aparicio Wilhelmi, 297-328. Barcelona: Icaro Editorial S.A., 2011.

Bonilla Maldonado, Daniel. La Constitución multicultural. Bogotá: Facultad de Derecho de la Universidad de los Andes, Pontificia Universidad Javeriana — Instituto Pensar, Siglo del Hombre Editores, 2006.

Borrero García, Camilo. “¿Multiculturalismo o interculturalidad?”. En Derecho, interculturalidad y resistencia étnica, editado por Diana González Carrillo y Nelson Santiago Rengifo Patarroyo, 67-75. Bogotá: Facultad de Derecho, Ciencias Políticas y Sociales de la Universidad Nacional de Colombia, Unijus, 2009.

Borrero García, Camilo. Derechos multiculturales (étnicos) en Colombia. Una dogmática ambivalente. Bogotá: Universidad Nacional de Colombia (sede Bogotá), Facultad de Derecho, Ciencias Políticas y sociales, Departamento de Derecho - Área Curricular, 2014. 
Botero Marino, Catalina. "Multiculturalismo y derechos de los pueblos indígenas en la jurisprudencia de la Corte Constitucional". En Precedente Anuario Jurídico 2003, 45-87. Cali: Centro de Investigaciones Sociojurídicas, Facultad de Derecho y Ciencias Sociales, Universidad Icesi, 2003.

Castrillón Orrego,Juan Diego. "Globalización y derechos indígenas en la Constitución de 1991 de Colombia”. En Representaciones legales de la alteridad indígena, editado por Herinaldy Gómez y Cristóbal Gnecco, 157-197. Popayán: Colciencias, Editorial Universidad del Cauca, 2008.

Colombia, Caja Agraria, Incora, Inderena y División Operativa de Asuntos Indígenas. Politica del gobierno nacional para la defensa de los derechos indígenas y la conservación ecológica de la cuenca amazónica. Bogotá: Estudio 3 - A Sandri Ltda, 1990.

Colombia, Dane (Departamento Administrativo Nacional de Estadística). Censo 2005. Consultado enero 12, 2013. www.dane.gov.co.

Colombia, DnP (Departamento Nacional de Planeación). Bases del Plan Nacional de Desarrollo 2010-2014. Prosperidad para todos. Bogotá: Departamento Nacional de Planeación, 2011.

Colombia, Presidencia de la República. Tejiendo el canasto de la vida. Bogotá: Programa Presidencial para la Formulación de Estrategias y Acciones para el Desarrollo Integral de los Pueblos Indígenas de Colombia, 2012. Colombia, Presidencia de la República. Plan Nacional de Desarrollo 2010-2014. Anexo IV. Acuerdos con los pueblos indígenas. Bases para el programa de garantías de los derechos fundamentales de los pueblos indígenas. Bogotá: Programa Presidencial para la Formulación de Estrategias y Acciones para el Desarrollo Integral de los Pueblos Indígenas de Colombia, 2012a.

Colombia, Presidencia de la República. ODM e indígenas. Una aproximación a los cuatro primeros objetivos. Bogotá: Programa Presidencial para la Formulación de Estrategias y Acciones para el Desarrollo Integral de los Pueblos Indígenas de Colombia, 2013.

Corte IDH (Corte Interamericana de Derechos Humanos). Caso del Pueblo Saramaka Vs Surinam. Sentencia de 28 de noviembre, 2007.

Cortés Gómez, Juan Alberto. "Tras lo social y lo cultural: la interculturalidad como manifestación de los movimientos sociales". En Derecho, interculturalidad y resistencia étnica, editado por Diana González Carrillo y Nelson Santiago Rengifo Patarroyo, 169-186. Bogotá: Facultad de Derecho, 
Ciencias Políticas y Sociales de la Universidad Nacional de Colombia, Unijus, 2009.

CSJ (Consejo Superior de la Judicatura) y onic (Organización Nacional Indígena de Colombia). "Pronunciamientos de las organizaciones y pueblos indígenas frente a los actores armados. REsOLUCIÓN DE vitonco. Febrero de 1985". En Compilación y selección de los fallos y decisiones de la jurisdicción especial indígena 1980-2006. Bogotá: Consejo Superior de la Judicatura - Organización Nacional Indígena de Colombia, 2006.

DGAI, DGN, Ecopetrol, UPME y mma. Guía de consulta previa a comunidades indigenas y negras. Bogotá: Ediciones Antropos Ltda, 1999.

DGAI (Dirección General de Comunidades Indígenas) - Colombia, Ministerio del Interior. Los pueblos indígenas en el país y en América. Elementos de política colombiana e internacional. Bogotá: Dirección General de Comunidades Indígenas, 1998.

Espinosa Arango, Mónica L. La civilización montés. La visión india y el trasegar de Manuel Quintín Lame en Colombia. Bogotá: Universidad de los Andes, Facultad de Ciencias Sociales, Departamento de Antropología, Centro de Estudios Socioculturales e Internacionales (Ceso), 2009.

Estrada Vélez, Sergio Iván. Los principios jurídicos y el bloque de constitucionalidad. Medellín: Universidad de Medellín, 2007.

Fajardo Sánchez, Luis Alfonso, Juan Carlos Gamboa Martínez y Orlando Villanueva Martínez. Manuel Quintin Lame y los guerreros de Juan Tama. Multiculturalismo, magia y resistencia. Bogotá: Nossa y Jara Editores, 1999. Fals Borda, Orlando. "Algunos ingredientes básicos". En Acción y conocimiento. Cómo romper el monopolio con investigación-acción participativa, editado por Orlando Fals Borda y Anisur Rahman, 9-19. Bogotá: Cinep, 1991.

Fondo Indígena (Fondo para el Desarrollo de los Pueblos Indígenas de América Latina y el Caribe). Sistema para el monitoreo de la protección de los derechos y la promoción del Buen Vivir de los pueblos indigenas. Manual de uso del sistema y experiencias de aplicación. La Paz: Fondo para el Desarrollo de los Pueblos Indígenas de América Latina y el Caribe, 2012.

Fraser, Nancy. Iustitia Interrupta: Reflexiones críticas desde la posición "postsocialista". Bogotá: Siglo del Hombre Editores, Universidad de los Andes, Facultad de Derecho, 1997.

Fraser, Nancy. "La justicia social en la era de la política de identidad: redistribución, reconocimiento y participación”. Revista de Trabajo (2008): 83-99. 
Consultado junio 30, 2013. http://www.trabajo.gov.ar/left/estadisticas/ descargas/revistaDeTrabajo/2009n06_revistaDeTrabajo/2009n06_a05_ nFraser.pdf.

García Lozano, Luisa Fernanda. "La jurisprudencia indígena de la Corte Constitucional Colombiana. ¿El resultado de prácticas emancipadoras o adaptativas?". En Pueblos indigenas. Constituciones y reformas politicas en América Latina, editado por Raquel Z. Yrigoyen Fajardo, 133-152. Lima: Instituto Internacional de Derechos y Sociedad (IIDs), Instituto de Estudios Socioeconómicos (Ines), Instituto Latinoamericano para una Sociedad y un Desarrollo Alternativos (Ilsa), 2010.

Gómez, Augusto. Indios, colonos y conflictos. Una historia regional de los Llanos Orientales. 1870-1970. Bogotá: Siglo xxi Editores, Pontificia Universidad Javeriana, Instituto de Antropología, 1991.

Gómez Isa, Felipe. "Prólogo”. En Los pueblos indígenas y el derecho, coordinado por José Aywin Oyarzún, 19-22. Santiago de Chile: s. n., 2013.

González, Esperanza y Fabio Velásquez. ¿Qué ha pasado con la participación ciudadana en Colombia?. Bogotá: Fundación Corona, 2003.

Gros, Christian. Colombia indigena. Identidad cultural y cambio social. Bogotá: Ceres, 1991.

Grueso Castelblanco, Libia Rosario. El derecho de los pueblos indigenas a la consulta previa, libre e informada. Una guía de información y reflexión para la aplicación desde la perspectiva de los Derechos Humanos. Bogotá: Oficina en Colombia del Alto Comisionado de las Naciones Unidas para los Derechos Humanos, 2008.

Hernández Meza, Nelson. "La aplicación del principio de la armonización concreta en la solución de conflictos entre derechos fundamentales". Revista de Derecho (2003): 198-223.

Huanacani Mamani, Fernando. Buen Vivir/Vivir Bien. Filosofía, politicas, estrategias y experiencias regionales andinas. Lima: Coordinadora Andina de Organizaciones Indígenas, 2010.

Ibarra Palafox, Francisco. Multiculturalismo e instituciones politico-constitucionales. México: Instituto de Investigaciones Jurídicas, Universidad Nacional Autónoma de México, 2007.

Kymlicka, Will. Ciudadanía multicultural. Una teoría liberal de los derechos de las minorías. Barcelona: Paidós, 1996. 
Lame, Manuel Quintín. Las luchas del indio que bajó de la montaña al valle de la civilización. Bogotá: Comité de Defensa del Indio, 1973.

Laurent, Virginie. Comunidades indígenas, espacios politicos y movilización electoral en Colombia, 1990-1998. Motivaciones, campos de acción e impactos. Bogotá: Instituto Francés de Estudios Andinos, Instituto Colombiano de Antropología e Historia, 2005.

Lopera Mesa, Gloria Patricia y Esteban Hoyos Ceballos. "Fronteras difusas. Apuntes sobre el surgimiento de la jurisdicción especial indígena en Colombia y sus relaciones con el derecho estatal". Revista Co-herencia 5 (2008): 143-168.

López Medina, Diego Eduardo. El derecho de los jueces. Obligatoriedad del precedente constitucional, análisis de sentencias y lineas jurisprudenciales y teoría del derecho judicial. Bogotá: Legis, 2007.

Mariátegui,José Carlos. Siete ensayos sobre la realidadperuana. Lima: Corporación Editora Chirre S. A., 2007.

Mayorga García, Fernando. Estudios de derecho indiano. Bogotá: Universidad del Rosario, 2003.

Mesa Cuadros, Gregorio. Derechos ambientales en perspectiva de integralidad. Concepto y fundamentación de nuevas demandas y resistencias actuales hacia el Estado Ambiental de Derecho. Bogotá: Universidad Nacional de Colombia,2007. MPC (Mesa Permanente de Concertación). De gobierno a gobierno. Tejiendo escenarios nacionales de concertación desde los pueblos y organizaciones indigenas con el gobierno nacional. Bogotá: MPc, Equipo Secretaría Técnica Indígena de la Mesa Permanente de concertación con pueblos y organizaciones indígenas, 2013.

Muelas Hurtado, Lorenzo. Ley 21 de 1991 que ratifica el Convenio 169 de la OIT. Bogotá: Fondo de Publicaciones del Senado de la República, 1997.

Muñoz Onofre, Juan Pablo. "La brecha entre el reconocimiento y la implementación de los derechos territoriales de los pueblos indígenas de Colombia: un análisis sobre su configuración en las normas, las políticas y los jueces tras la aprobación de la Constitución Política de 1991”. Tesis de Maestría, Universidad del Rosario, Bogotá, 2014.

Naranjo Peña, Edgar Ricardo. "De la lucha por la tierra al reconocimiento de los Derechos Humanos: genealogía discursiva del Consejo Regional Indígena del Cauca”. En Identidades politicas porosas. Estudios sobre las reivindicaciones sociales nacionales $y$ transnacionales, editado por Ángela Santamaría 
Chavarro, Edgar Ricardo Naranjo Peña, Mónica Acosta García, Ana Catalina Rodríguez Moreno y Pedro Rojas Oliveros, 131-186. Bogotá: Universidad del Rosario, 2012.

oit (Organización Internacional del Trabajo). Actas provisionales. Septuagésima sexta reunión. Revisión parcial del Convenio sobre poblaciones indígenas y tribales. Ginebra: Organización Internacional del Trabajo, 1989.

OIT (Organización Internacional del Trabajo). Guia para la aplicación del Convenio núm. 169 de la OIT. Consultado enero 12,2013. http://oit.or.cr/mdtsanjo/ indig/conten.htm.

OIT (Organización Internacional del Trabajo). Los derechos de los pueblos indígenas y tribales en la práctica: una guía sobre el Convenio núm. 169 de la OIT. Ginebra: Organización Internacional del Trabajo, 2009.

OIT (Organización Internacional del Trabajo). Manual para los mandantes tripartitos de la OIT. Comprender el Convenio sobre pueblos indígenas y tribales, 1989 (núm. 169). Programa para promover el Convenio 169 (Pro 169). Ginebra: Oficina Internacional del Trabajo, 2013.

oIt (Organización Internacional del Trabajo). Ratificación del C169 - Convenio sobre los pueblos indígenas y tribales, 1989 (núm. 169). Consultado abril 12, 2015. http://www.ilo.org/dyn/normlex/es/f?p=NORMLEXPUB:11300:0:: N o::P11300_INSTRUMENT_ID:312314.

onic (Organización Nacional Indígena de Colombia). Derechos de los pueblos indigenas y sistemas de Jurisdicción Propia. Bogotá: ONIC, 2007a.

ONIC (Organización Nacional Indígena de Colombia). Quintin Lame, los pensamientos del indio que se educó dentro de las selvas colombianas. Bogotá: ONIC, 2007b.

ONIC (Organización Nacional Indígena de Colombia). Palabra dulce, aire de vida. Forjando caminos para la pervivencia de los pueblos indígenas en riesgo de extinción en Colombia. Reaccionemos. 2010-2011. Bogotá: ONIc, 2010.

onu (Organización de Naciones Unidas). Los derechos de los Pueblos Indígenas (1998).

ONu (Organización de Naciones Unidas). "Informe del Relator Especial sobre la situación de los derechos humanos y las libertades fundamentales de los indígenas, Sr. Rodolfo Stavenhagen”. Comisión de Derechos Humanos. Adición Misión a Colombia, E/cN.4/2005/88/Add.2, noviembre 10,2004. 
ONU (Organización de Naciones Unidas). "Declaración de las Naciones Unidas sobre los derechos de los pueblos indígenas”. Asamblea General. Sexagésimo primer período de sesiones. A/REs/61/295, Nueva York, septiembre, 2007a. onv (Organización de Naciones Unidas). Objetivos de desarrollo del Milenio. Informe de 2007. Nueva York: ONU, 2007b.

onu (Organización de Naciones Unidas). Informe de la Alta Comisionada para los Derechos Humanos sobre la situación de los derechos humanos en Colombia. Bogotá: ONU, 2013.

Pagliari, Arturo Santiago. "Reflexiones sobre la fragmentación del derecho internacional. Aplicación y efectos". Ars Boni et Aequi (2009): 11-38.

Pineda Camacho, Roberto. "Pueblos indígenas de Colombia: una aproximación a su historia, economía y sociedad". En Tierra profanada, grandes proyectos en territorios indigenas de Colombia, editado por ONIC, CECOIN, GhK, 1-37. Bogotá: Disloque Editores, 1995.

Quinche Ramírez, Manuel. El control de convencionalidad. Bogotá: Editorial Temis S.A., 2014.

Rappaport, Joanne. Utopias interculturales. Interculturales públicos, experimentos con la cultura y pluralismo étnico en Colombia. Bogotá: Editorial Universidad del Rosario, 2008.

Regalado Gutiérrez, José. "Los derechos de los pueblos indígenas: un reto para la gobernabilidad, la democracia y la ciudadanía”. Diálogo Político, publicación trimestral de la Konrad-Adenauer-Stiftung A. C. (2010): 59-71.

Resguardo de Vitoncó. Resolución de Vitoncó. Cauca: Resguardo de Vitoncó, sin publicar.

Rodríguez, Gloria Amparo. "La consulta previa a pueblos indígenas". En Comunidades étnicas en Colombia. Cultura y jurisprudencia, 114-142. Bogotá: Universidad del Rosario, 2005.

Rodríguez, Gloria Amparo. "Breve reseña de los derechos constitucionales de las comunidades étnicas colombianas". En Teoría constitucional Liber Amicorum en homenaje a Vladimiro Naranjo Mesa,198-220. Bogotá: Universidad del Rosario, 2006.

Rodríguez, Gloria Amparo. "Argumentos para la resistencia cultural de los pueblos indígenas de Colombia contra el TLC". En El Tratado de Libre Comercio, la integración comercial y el derecho de los Mercados, editado por Erick Rincón Cárdenas, Erwin Santamaría Ariza y Juan Jacobo Calderón Villegas, 110-127. Bogotá: Universidad del Rosario. 
Rodríguez, Gloria Amparo "La autonomía y los conflictos ambientales en territorios indígenas" En La tierra contra la muerte. Conflictos territoriales de los pueblos indígenas en Colombia, editado por Juan Houghton. Bogotá: Observatorio Indígena de Políticas Públicas de Desarrollo y Derechos Étnicos, Centro de Cooperación al Indígena Cecoin, Organización Indígena de Antioquia (oIA), 2008.

Rodríguez, Gloria Amparo. "Conflictos sociales, ambientales y culturales en el 'Corazón del Mundo': la Sierra Nevada de Santa Marta (Colombia)”.En Conflictos y judicialización de la politica en la Sierra Nevada de Santa Marta, editado por Alexandra Mora Rodríguez, Edgar Ricardo Naranjo Peña, Gloria Amparo Rodríguez y Ángela Santamaría Chavarro, 201-256. Bogotá: Universidad del Rosario, 2010.

Rodríguez, Gloria Amparo. De la consulta previa al consentimiento libre, previo e informado a pueblos indígenas en Colombia. Bogotá: GIz, Universidad del Rosario, 2014.

Rodríguez, Gloria Amparo y Lina Marcela Muñoz. La participación en la gestión ambiental: un reto para el nuevo milenio. Bogotá: Universidad del Rosario, 2009.

Rodríguez, Gloria Amparo y Alejandra Sáenz Quitian. "La lucha de los pueblos indígenas por la permanencia del corazón del mundo. Aspectos culturales y jurídicos”. En Escuela intercultural de diplomacia indígena. Memoria, derecho y participación, editado por Ana Catalina Rodríguez Moreno, Pedro Rojas Oliveros y Ángela Santamaría Chavarro, 265-295. Bogotá: Universidad del Rosario, 2012.

Rodríguez, Gloria Amparo, Claudia Ardila Ibagón y Alejandro Puentes Vargas. "El laberinto jurídico de los U'wa en ejercicio del derecho a la resistencia". Diálogo de Saberes (2010): 173-193.

Roldán Ortega, Roque. Pueblos indigenas y leyes en Colombia. Aproximación crítica al estudio de su pasado y su presente. Bogotá: Gaia, Coama (Consolidación Amazónica) y oiт (Organización Internacional del Trabajo), 2000.

Sánchez Bella, Ismael, Alberto De La Hera y Carlos Díaz Rementería. Historia del derecho indiano. Madrid: Editorial Mapfre, 1992.

Sánchez Botero, Esther. "El reto del multiculturalismo jurídico. La justicia de la sociedad mayor y la justicia indígena”. En El caleidoscopio de las justicias en Colombia. Análisis socio-jurídico, editado por Boaventura de Sousa Santos 
y Mauricio García Villegas, 5-142, Tomo II. Bogotá: Siglo del Hombre Editores, Universidad de los Andes, 2001.

Sánchez Botero, Esther e Isabel Crsitina Jaramillo Sierra. La jurisdicción especial indigena. Bogotá: Procuraduría General de la Nación, 2000.

Santamaría,Ángela. Redes transnacionales y emergencia de la diplomacia indígena: un estudio a partir del caso colombiano. Bogotá: Universidad del Rosario, 2008. Santamaría, Ángela. "Movilización jurídica y derecho internacional de los derechos humanos: un análisis de las prácticas de incidencia en política de la ONIC". En Jano y las caras opuestas de los derechos humanos de los pueblos indígenas, editado por Roddy Brett y Ángela Santamaría, 177-206. Bogotá: Universidad del Rosario, 2010.

Santos, Boaventura de Sousa. Refundación del Estado en América Latina. Perspectivas desde una epistemología del Sur. Lima: Instituto Internacional de Derecho y Sociedad, Programa Democracia y Transformación Global, 2010.

Stavenhagen, Rodolfo. Conflictos étnicos y Estado nacional. México: Siglo xxI Editores, 2000.

Stavenhagen, Rodolfo. “Los pueblos indígenas y sus derechos”. Consultado abril 8, 2015. http://www.cinu.org.mx/prensa/especiales/2008/Indigenas/libro\%20pdf/Libro\%20Stavenhagen\%20unesco.pdf

Tauli-Corpuz, Victoria. "El reto de ejecutar la Declaración de la onu sobre los derechos de los pueblos indígenas". En La Declaración sobre los derechos de los pueblos indigenas. Punto y seguido, coordinado por Mikel Berraondo López, 9-18. Barcelona: Alternativa Intercambio con Pueblos Indígenas. Taylor, Charles. Multiculturalismo y la "politica del reconocimiento". Sevilla: Fondo de Cultura Económica, 2003.

Vega Cantor, Renán. Gente muy rebelde. 2. Indígenas, campesinos y protestas agrarias. Bogotá: Ediciones Pensamiento Crítico, 2002.

Villavicencio Miranda, Luis. "Un diálogo intercultural más allá del multiculturalismo”. Revista Opinión Jurídica 11 (2012): 31-44.

Yrigoyen Fajardo, Raquel Z. "A los veinte años del Convenio 169 de la oIT: balance y retos de implementación de los derechos de los pueblos indígenas en Latinoamérica". En Pueblos indígenas. Constituciones y reformas politicas en América Latina, editado por Raquel Z. Yrigoyen Fajardo, 15-80. Lima: Instituto Internacional de Derechos y Sociedad (IIDs), Instituto de Estudios Socioeconómicos (Ines), Instituto Latinoamericano para una Sociedad y un Desarrollo Alternativos (Ilsa). 


\section{Fuentes jurídicas nacionales e internacionales}

\section{Fuentes nacionales}

\section{Constitución Política de Colombia}

Constitución Política de Colombia. 7 de julio de 1991. Colombia.

\section{Leyes}

Ley 89 de 1890, por la cual se determina la manera como deben ser gobernados los salvajes que vayan reduciéndose a la vida civilizada. Colombia.

Ley 55 de 1905, por la cual se ratifica la venta de varios bienes nacionales y se hace cesión de otros. Colombia.

Ley 51 de 1911, por la cual se ceden unos terrenos baldíos al Departamento de Nariño y se manda fundar una población. Colombia.

Ley 106 de 1913, por la cual se adiciona y reforma la ley 51 de 1911 y ratifica una cesión de terrenos baldíos. Colombia.

Ley 19 de 1927, por la cual se dictan algunas normas sobre división de resguardos indígenas. Colombia.

Ley 31 de 1967, por la cual se aprueba el Convenio Internacional del Trabajo, relativo a la protección e integración de las poblaciones indígenas y tribales en los países independientes, adoptado por la cuadragésima reunión de la Conferencia General de la Organización Internacional del Trabajo (Ginebra, 1957). Colombia.

Ley 74 de 1968, por la cual se aprueban los Pactos Internacionales de Derechos Económicos, Sociales y Culturales, de Derechos Civiles y Políticos, así como el Protocolo Facultativo de este último, aprobado por la Asamblea General de las Naciones Unidas en votación Unánime, en Nueva York, el 16 de diciembre de 1966.

Ley 17 de 1981, por la cual se aprueba la "Convención sobre el Comercio Internacional de Especies Amenazadas de Fauna y Flora Silvestres”, suscrita en Washington, D.C. el 3 de marzo de 1973.

Ley 12 de 1991, por medio de la cual se aprueba la Convención sobre los Derechos Del Niño adoptada por la Asamblea General de las Naciones Unidas el 20 de noviembre de 1989.

Ley 21 de 1991, por medio de la cual se aprueba el "Convenio núm. 169 sobre pueblos indígenas y tribales en países independientes”, adoptado por la 
76a. Reunión de la Conferencia General de la Organización Internacional del Trabajo (Ginebra, 1989). Colombia.

Ley 5 de 1992, por la cual se expide el Reglamento del Congreso; el Senado y la

Cámara de Representantes. Colombia.

Ley 70 de 1993, por la cual se desarrolla el artículo transitorio 55 de la Constitución Política. Colombia.

Ley 99 de 1993, por la cual se crea el Ministerio del Medio Ambiente, se reordena el Sector Público encargado de la gestión y conservación del medio ambiente y los recursos naturales renovables, se organiza el Sistema Nacional Ambiental, Sina, y se dictan otras disposiciones. Colombia.

Ley 160 de 1994, por la cual se crea el Sistema Nacional de Reforma Agraria y

Desarrollo Rural Campesino, se establece un subsidio para la adquisición de tierras, se reforma el Instituto Colombiano de la Reforma Agraria y se dictan otras disposiciones. Colombia.

Ley 165 de 1994, por medio de la cual se aprueba el "Convenio sobre la Diversidad Biológica”, suscrito en Río de Janeiro, el 5 de junio de 1992. Colombia. Ley 397 de 1997, por la cual se desarrollan los artículos 70, 71 y 72 y demás artículos concordantes de la Constitución Política y se dictan normas sobre patrimonio cultural, fomentos y estímulos a la cultura, se crea el Ministerio de la Cultura y se trasladan algunas dependencias. Colombia.

Ley 1381 de 2010, por la cual se desarrollan los artículos 7o, 8o, 10 y 70 de la Constitución Política, y los artículos 4o, 5o y 28 de la Ley 21 de 1991 (que aprueba el Convenio núm. 169 de la ort sobre pueblos indígenas y tribales), y se dictan normas sobre reconocimiento, fomento, protección, uso, preservación y fortalecimiento de las lenguas de los grupos étnicos de $\mathrm{Co}^{-}$ lombia y sobre sus derechos lingüísticos y los de sus hablantes. Colombia.

Ley 1444 de 2011, por medio de la cual se escinden unos Ministerios, se otorgan precisas facultades extraordinarias al Presidente de la República para modificar la estructura de la Administración Pública y la planta de personal de la Fiscalía General de la Nación, y se dictan otras disposiciones. Colombia. Ley 1482 de 2011, por medio de la cual se modifica el Código Penal y se establecen otras disposiciones. Colombia.

Ley 1712 de 2014, por medio de la cual se crea la Ley de Transparencia y del Derecho de Acceso a la Información Pública Nacional y se dictan otras disposiciones. Colombia. 


\section{Acuerdos / decretos / resoluciones}

Decreto 2001 de 1988 [Ministerio de Agricultura], por el cual se reglamenta el inciso final del Artículo 29, el inciso 3o. y el parágrafo 1o. del Artículo 94 de la Ley 135 de 1961 en lo relativo a la Constitución de Resguardos Indígenas en el territorio nacional.

Decreto 2164 de 1995 [Ministerio de Agricultura], por el cual se reglamenta parcialmente el Capítulo XIv de la Ley 160 de 1994 en lo relacionado con la dotación y titulación de tierras a las comunidades indígenas para la constitución, reestructuración, ampliación y saneamiento de los Resguardos Indígenas en el territorio nacional. Colombia.

Decreto 1396 de 1996 [Ministerio del Interior y de Justicia], por medio del cual se crea la Comisión de Derechos Humanos de los Pueblos Indígenas y el Programa Especial de Atención a los Pueblos Indígenas. Colombia.

Decreto 1397 de 1996 [República de Colombia], por el cual se crea la Comisión Nacional de Territorios Indígenas y la Mesa Permanente de Concertación con los pueblos y organizaciones indígenas y se dictan otras disposiciones. Colombia.

Decreto 1320 de 1998 [República de Colombia], por el cual se reglamenta la consulta previa con las comunidades indígenas y negras para la explotación de los recursos naturales dentro de su territorio. Colombia.

Decreto 2893 de 2011 [República de Colombia], por el cual se modifican los objetivos, la estructura orgánica y funciones del Ministerio del Interior y se integra el Sector Administrativo del Interior. Colombia.

Decreto-Ley 4633 de 2011 [República de Colombia], por medio del cual se dictan medidas de asistencia, atención, reparación integral y de restitución de derechos territoriales a las víctimas pertenecientes a los pueblos y comunidades indígenas. Colombia.

Decreto 2613 de 2013 [República de Colombia], por el cual se adopta el Protocolo de Coordinación Interinstitucional para la consulta previa. Colombia.

\section{Otras normas}

Directiva Presidencial 01 de 2010. [Presidencia de la República]. Directiva del Presidente de la República dirigida al Vicepresidente, Ministros del Despacho, Directores de los Departamentos Administrativos, Superintendentes y Directores, Gerentes y Organismos del Sector Central y 
Descentralizado del Orden Nacional, para la garantía del derecho fundamental a la consulta previa de los grupos étnicos nacionales. Colombia. Directiva Presidencial 10 de 2013. [Presidencia de la República]. Directiva del Presidente de la República dirigida a los funcionarios y que contiene la Guía para al realización de la consulta previa, la cual debe utilizarse como herramienta de coordinación interinstitucional, para el logo de le eficiencia administrativa y las prácticas de buen gobierno, en los procesos de consulta previa a las comunidades étnicas para el desarrollo de proyectos, como obras o actividades. Colombia.

\section{Jurisprudencia}

Corte Constitucional. Sentencia T-188 de 1993 (M.P. Eduardo Cifuentes Muñoz). Colombia.

Corte Constitucional. Sentencia T-257 de 1993 (M. P. Alejandro Martínez Caballero). Colombia.

Corte Constitucional. Sentencia T-308 de 1993 (M.P. Eduardo Cifuentes Muñoz). Colombia.

Corte Constitucional. Sentencia T-380 de 1993 (M.P. Eduardo Cifuentes Muñoz). Colombia.

Corte Constitucional. Sentencia T-405 de 1993.(M.P.Hernando Herrera Vergara). Colombia.

Corte Constitucional. Sentencia T-254 de 1994. (M. P. Eduardo Cifuentes Muñoz). Colombia.

Corte Constitucional. Sentencia T-342 de 1994. (M. P. Antonio Barrera Carbonell). Colombia.

Corte Constitucional. Sentencia C-104 de 1995. (M. P.Hernando Herrera Vergara). Colombia.

Corte Constitucional. Sentencia C-037 de 1996. (M. P. Vladimiro Naranjo Mesa). Colombia.

Corte Constitucional. Sentencia C-138 de 1996. (M.P. José Gregorio Hernández) Galindo. Colombia.

Corte Constitucional. Sentencia C-139 de 1996. (M. P. Carlos Gaviria Díaz). Colombia.

Corte Constitucional. Sentencia T-349 de 1996. (M. P. Carlos Gaviria Díaz). Colombia. 
Corte Constitucional. Sentencia su-039 de 1997. (M. P. Antonio Barrera Carbonell). Colombia.

Corte Constitucional. Sentencia T-523 de 1997 (M. P. Carlos Gaviria Díaz). Colombia.

Corte Constitucional. Sentencia su-510 de 1998. (M. P. Eduardo Cifuentes Muñoz). Colombia.

Corte Constitucional. Sentencia T-344 de 1998. (M. P. Alfredo Beltrán Sierra). Colombia.

Corte Constitucional. Sentencia T-525 de 1998. (M.P.José Gregorio Hernández Galindo). Colombia.

Corte Constitucional. Sentencia T-652 de 1998. (M. P. Carlos Gaviria Díaz. Colombia.

Corte Constitucional. Sentencia T-667A de 1998. (M.P. Antonio Barrera Carbonell). Colombia.

Corte Constitucional. Sentencia T-266 de 1999. (M. P. Carlos Gaviria Díaz). Colombia.

Corte Constitucional. Sentencia T-634 de 1999. (M. P. Alejandro Martínez Caballero). Colombia.

Corte Constitucional. Sentencia T-934 de 1999. (M. P. Carlos Gaviria Díaz. Colombia.

Corte Constitucional. Sentencia C-795 de 2000. (M. P. Eduardo Cifuentes Muñoz). Colombia.

Corte Constitucional. Sentencia C-169 de 2001. (M. P. Carlos Gaviria Díaz). Colombia.

Corte Constitucional. Sentencia C- 825 de 2001 (M. P. Manuel José Cepeda Espinosa). Colombia.

Corte Constitucional. Sentencia C-892 de 2001. (M. P. Rodrigo Escobar Gil). Colombia.

Corte Constitucional. Sentencia T-116 de 2001. (M.P.Martha Victoria Sáchica Méndez). Colombia.

Corte Constitucional. Sentencia T-606 de 2001. (M.P. Marco Gerardo Monroy Cabra). Colombia.

Corte Constitucional. Sentencia T-1127 de 2001. (M.P.Jaime Araújo Rentería). Colombia

Corte Constitucional. Sentencia T-1303 de 2001. (M.P.Marco Gerardo Monroy) Cabra). Colombia. 
Corte Constitucional. Sentencia C-370 de 2002. (M. P. Eduardo Montealegre Lynett). Colombia.

Corte Constitucional. Sentencia C-418 de 2002. (M. P. Álvaro Tafur Galvis). Colombia.

Corte Constitucional. Sentencia C-891 de 2002. (M. P.Jaime Araújo Rentería). Colombia.

Corte Constitucional. Sentencia T-048 de 2002. (M. P. Álvaro Tafur Galvis). Colombia.

Corte Constitucional. Sentencia T-239 de 2002. (M. P. Alfredo Beltrán Sierra). Colombia.

Corte Constitucional. Sentencia T-728 de 2002.(M.P.Jaime Córdoba Triviño). Colombia.

Corte Constitucional. Sentencia C-063 de 2003. (M. P. Clara Inés Vargas Hernández). Colombia.

Corte Constitucional. Sentencia C-127 de 2003. (M.P. Alfredo Beltrán Sierra). Colombia.

Corte Constitucional. Sentencia C-620 de 2003. (M.P.Marco Gerardo Monroy Cabra). Colombia.

Corte Constitucional. Sentencia su-383 de 2003. (M. P. Álvaro Tafur Galvis). Colombia.

Corte Constitucional. Sentencia T-379 de 2003. (M. P. Clara Inés Vargas Hernández). Colombia.

Corte Constitucional. Sentencia T-552 de 2003. (M. P. Rodrigo Escobar Gil). Colombia.

Corte Constitucional. Sentencia T-955 de 2003. (M. P. Álvaro Tafur Galvis). Colombia.

Corte Constitucional. Sentencia C-245 de 2004. (M. P. Clara Inés Vargas Hernández). Colombia.

Corte Constitucional. Sentencia T-811 de 2004. (M.P.Jaime Córdoba Triviño). Colombia.

Corte Constitucional. Sentencia T-1238 de 2004. (M. P. Rodrigo Escobar Gil). Colombia.

Corte Constitucional. Sentencia C-180 de 2005. (M.P.Humberto Sierra Porto). Colombia

Corte Constitucional. Sentencia T-737 de 2005. (M. P. Álvaro Tafur Galvis). Colombia. 
Corte Constitucional. Sentencia T-778 de 2005. (M. P. Manuel José Cepeda Espinosa). Colombia.

Corte Constitucional. Sentencia T-1070 de 2005. (M. P. Rodrigo Escobar Gil). Colombia.

Corte Constitucional. Sentencia T-1294 de 2005. (M. P. Clara Inés Vargas Hernández). Colombia.

Corte Constitucional. Sentencia T-382 de 2006. (M. P. Clara Inés Vargas Hernández). Colombia.

Corte Constitucional. Sentencia T-349 de 2006. (M. P. Rodrigo Escobar Gil). Colombia.

Corte Constitucional. Sentencia T-704 de 2006. (M. P. Humberto Antonio Sierra Porto). Colombia.

Corte Constitucional. Sentencia T-880 de 2006. (M. P. Álvaro Tafur Galvis). Colombia.

Corte Constitucional. Sentencia T-979 de 2006. (M. P. Nilson Pinilla Pinilla). Colombia.

Corte Constitucional. Sentencia C-208 de 2007 (M. P. Rodrigo Escobar Gil). Colombia.

Corte Constitucional. Sentencia C-921 de 2007. (M. P. Clara Inés Vargas Hernández). Colombia.

Corte Constitucional. Sentencia T-009 de 2007. (M. P. Manuel José Cepeda Espinosa). Colombia.

Corte Constitucional. Sentencia T-123 de 2007. (M. P. Álvaro Tafur Galvis). Colombia.

Corte Constitucional. Sentencia T-549 de 2007. (M.P.Jaime Araujo Rentería). Colombia.

Corte Constitucional. Sentencia T-945 de 2007. (M. P. Rodrigo Escobar Gil). Colombia.

Corte Constitucional. Sentencia T-996 de 2007. (M.P.Jaime Araujo Rentería). Colombia.

Corte Constitucional. Sentencia C-030 de 2008. (M. P. Rodrigo Escobar Gil). Colombia.

Corte Constitucional. Sentencia C-461 de 2008. (M. P. Manuel José Cepeda Espinosa). Colombia.

Corte Constitucional. Sentencia C-713 de 2008. (M. P. Clara Inés Vargas Hernández). Colombia. 
Corte Constitucional. Sentencia C-750 de 2008. (M. P. Clara Inés Vargas Hernández). Colombia.

Corte Constitucional. Sentencia T-703 de 2008. (M. P. Manuel José Cepeda Espinosa). Colombia.

Corte Constitucional. Sentencia T-1026 de 2008.(M.P. Marco Gerardo Monroy Cabra). Colombia.

Corte Constitucional. Sentencia T-1105 de 2008. (M. P. Humberto Antonio Sierra Porto). Colombia.

Corte Constitucional. Sentencia T-1253 de 2008. (M. P. Manuel José Cepeda Espinosa). Colombia.

Corte Constitucional. Sentencia C-175 de 2009. (M. P. Luis Ernesto Vargas Silva). Colombia.

Corte Constitucional. Sentencia C-615 de 2009. (M. P. Humberto Antonio Sierra Porto). Colombia.

Corte Constitucional. Sentencia T-013 de 2009. (M. P. Rodrigo Escobar Gil). Colombia.

Corte Constitucional. Sentencia T-113 de 2009. (M. P. Clara Elena Reales Gutiérrez). Colombia.

Corte Constitucional. Sentencia T-154 de 2009. (M. P. Nilson Pinilla Pinilla). Colombia.

Corte Constitucional. Sentencia T-514 de 2009. (M. P. Luis Ernesto Vargas Silva). Colombia.

Corte Constitucional. Sentencia T-769 de 2009. (M. P. Nilson Pinilla Pinilla). Colombia.

Corte Constitucional. Sentencia T-903 de 2009. (M. P. Luis Ernesto Vargas Silva). Colombia.

Corte Constitucional. Sentencia T-973 de 2009. (M. P. Mauricio González Cuervo). Colombia.

Corte Constitucional. Sentencia C-063 de 2010. (M. P. Humberto Sierra Porto). Colombia.

Corte Constitucional. Sentencia C-608 de 2010. (M.P.Humberto Sierra Porto). Colombia.

Corte Constitucional. Sentencia C-702 de 2010. (M. P. Jorge Ignacio Pretelt). Colombia.

Corte Constitucional. Sentencia C-915 de 2010. (M. P. Humberto Antonio Sierra Porto). Colombia. 
Corte Constitucional. Sentencia C-941 de 2010. (M. P. Jorge Iván Palacio Palacio). Colombia.

Corte Constitucional. Sentencia T-547 de 2010. (M. P. Gabriel Eduardo Mendoza Martelo). Colombia.

Corte Constitucional. Sentencia T-617 de 2010. (M. P. Luis Ernesto Vargas Silva). Colombia.

Corte Constitucional. Sentencia T-745 de 2010. (M. P. Humberto Antonio Sierra Porto). Colombia.

Corte Constitucional. Sentencia T-1045A de 2010. (M. P. Nilson Pinilla Pini1la). Colombia.

Corte Constitucional. Sentencia C-027 de 2011. (M. P. Jorge Ignacio Pretelt). Colombia.

Corte Constitucional. Sentencia C-187 de 2011. (M. P. Humberto Antonio Sierra Porto). Colombia.

Corte Constitucional. Sentencia C-366 de 2011. (M. P. Luis Ernesto Vargas Silva). Colombia.

Corte Constitucional. Sentencia C-367 de 2011. (M. P. Juan Carlos Henao Pérez). Colombia.

Corte Constitucional. Sentencia C-490 de 2011. (M. P. Luis Ernesto Vargas Silva). Colombia.

Corte Constitucional. Sentencia T-129 de 2011. (M. P. Jorge Iván Palacio Palacio). Colombia.

Corte Constitucional. Sentencia T-235 de 2011. (M. P. Luis Ernesto Vargas Silva). Colombia.

Corte Constitucional. Sentencia T-282 de 2011. (M. P. Luis Ernesto Vargas Silva). Colombia.

Corte Constitucional. Sentencia T-693 de 2011. (M. P. Jorge Ignacio Pretelt). Colombia.

Corte Constitucional. Sentencia C-196 de 2012. (M. P. María Victoria Calle Correa). Colombia.

Corte Constitucional. Sentencia C-293 de 2012. (M. P. Jorge Ignacio Pretelt). Colombia.

Corte Constitucional. Sentencia C-317 de 2012. (M. P. María Victoria Calle Correa). Colombia.

Corte Constitucional. Sentencia T-454 de 2013. (M.P. Nilson Pinilla Pinilla). Colombia. 
Corte Constitucional. Sentencia T-657 de 2013. (M.P. Maria Victoria Calle Correa). Colombia.

Corte Constitucional Sentencia C-463 de 2014. (M.P. Maria Victoria Calle Correa). Colombia. 

Este libro fue compuesto en caracteres Adobe Caslon Pro 11,5 puntos, impreso sobre papel propal de 70 gramos y encuadernado con método hot melt, en mayo de 2015, en Bogotá, D. C., Colombia. 